\title{
\#USGS
}

Prepared in cooperation with the Washington State Department of Ecology

\section{Data Compilation for Assessing Sediment and Toxic Chemical Loads from the Green River to the Lower Duwamish Waterway, Washington}

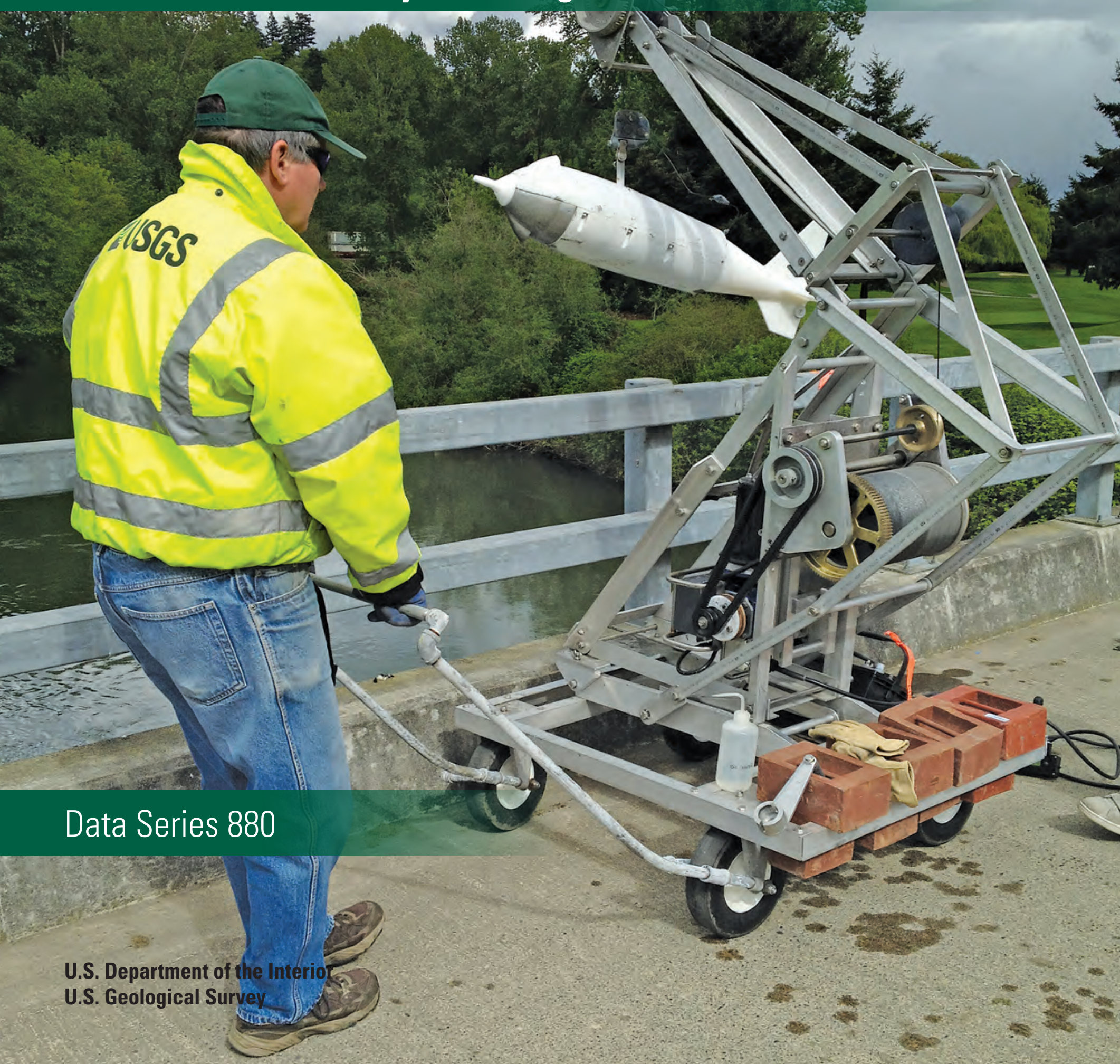


Cover: Photograph of U.S. Geological Survey personnel collecting water quality samples from the Duwamish River, Washington, with a D-96 sampler. (Photograph taken by Kathy Conn, U.S. Geological Survey, April 29, 2013.) 


\section{Data Compilation for Assessing Sediment and Toxic Chemical Loads from the Green River to the Lower Duwamish Waterway, Washington}

By Kathleen E. Conn and Robert W. Black

Prepared in cooperation with the Washington State Department of Ecology

Data Series 880 


\title{
U.S. Department of the Interior SALLY JEWELL, Secretary
}

\section{U.S. Geological Survey Suzette M. Kimball, Acting Director}

\author{
U.S. Geological Survey, Reston, Virginia: 2014
}

For more information on the USGS - the Federal source for science about the Earth, its natural and living resources, natural hazards, and the environment, visit http://www.usgs.gov or call 1-888-ASK-USGS.

For an overview of USGS information products, including maps, imagery, and publications, visit http://www.usgs.gov/pubprod

To order this and other USGS information products, visit http://store.usgs.gov

Any use of trade, firm, or product names is for descriptive purposes only and does not imply endorsement by the U.S. Government.

Although this information product, for the most part, is in the public domain, it also may contain copyrighted materials as noted in the text. Permission to reproduce copyrighted items must be secured from the copyright owner.

Suggested citation:

Conn, K.E., and Black, R.W., 2014, Data compilation for assessing sediment and toxic chemical loads from the Green River to the lower Duwamish Waterway, Washington: U.S. Geological Survey Data Series 880, 46 p., http://dx.doi. org/10.3133/ds880.

ISSN 2327-638X (online) 


\section{Contents}

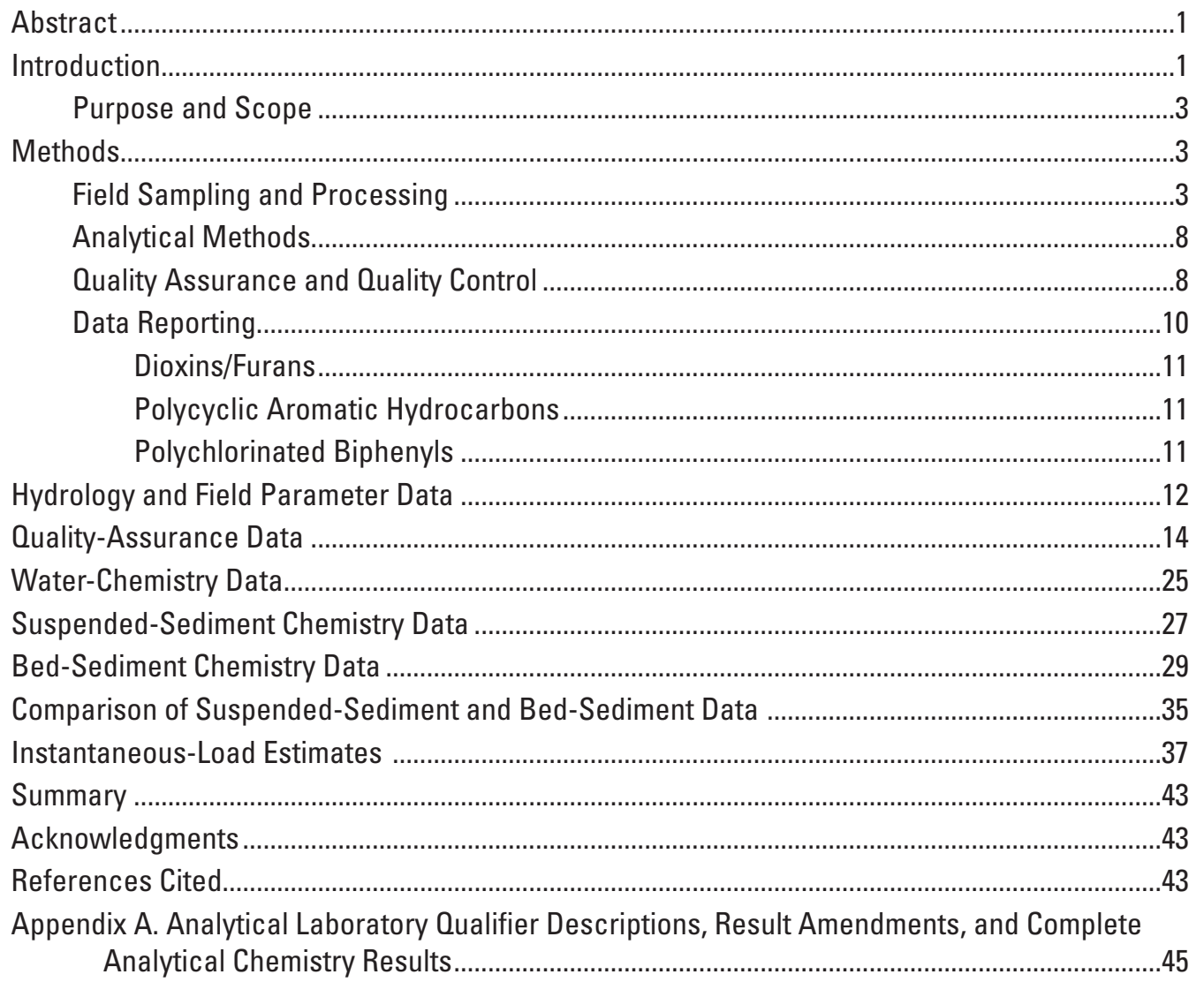

\section{Figures}

1. Map showing location of U.S. Geological Survey (USGS) sampling station relative to the Lower Duwamish Waterway, Seattle, Washington ..................................................2

2. Photograph showing selected sampling station, Duwamish River at Golf Course at Tukwila, Washington (12113390), located at river kilometer 16.7 .....................................

3. Hydrograph showing gage height and suspended- (bridge based) and bed- (boat based) sediment collected at U.S. Geological Survey streamgage 12113350, Green River at Tukwila, Washington, February-July 2013.

4. Graph showing concentrations of metals in whole-water samples, Duwamish River at Golf Course at Tukwila, Washington, 2013

5. Graph showing grain-size distribution of bulk bed-sediment samples ( $<2$ millimeters) and a single storm sample of suspended sediment, Duwamish River at Golf Course at Tukwila, Washington, 2013 


\section{Tables}

1. Field tasks, parameters collected, collection methods, references, and laboratories completing each task, Duwamish River at Golf Course at Tukwila, Washington, 2013 ....5

2. Field tasks and sampling dates at Duwamish River at Golf Course at Tukwila, Washington, 2013.

3. Analytical parameter groups, methods, and analyzing laboratory for samples collected at Duwamish River at Golf Course, at Tukwila, Washington, 2013

4. General hydrology, water quality, and field conditions during bridge-based sampling at Duwamish River at Golf Course at Tukwila, Washington, 2013.

5. Quality assurance results for whole water samples, Duwamish River at Golf Course at Tukwila, Washington, 2013.

6. Quality assurance results for suspended-sediment samples, Duwamish River at Golf Course at Tukwila, Washington, 2013.

7. Quality assurance results for bed-sediment samples, Duwamish River at Golf Course at Tukwila, Washington, 2013.

8. Quality assurance results for the Puget Sound Reference Material (PSRM), Duwamish River at Golf Course at Tukwila, Washington, 2013

9. Concentrations of detected compounds in whole water samples, Duwamish River at Golf Course at Tukwila, Washington, 2013

10. Compounds detected in suspended-sediment samples, Duwamish River at Golf Course at Tukwila, Washington, 2013.

11. Compounds detected in bulk bed-sediment samples ( $<2$ millimeters), Duwamish River at Golf Course at Tukwila, Washington, 2013.

12. Compounds detected in fine bed sediment samples $(<62.5$ micrometers), Duwamish River at Golf Course at Tukwila, Washington, 2013.

13. Comparison of total organic carbon, percent fines, average dry weight concentrations, and average organic carbon normalized concentrations of compounds in suspended sediment, fine bed sediment ( $<62.5$ micrometers), and bulk bed sediment ( $<2$ millimeters), Duwamish River at Golf Course at Tukwila, Washington, 2013

14. Instantaneous chemical loads based on concentrations in whole water, Duwamish River, Washington, 2013

15. Instantaneous suspended-sediment loads and chemical loads based on concentrations in suspended-sediment, Duwamish River at Golf Course at Tukwila, Washington, 2013 


\section{Conversion Factors, Datum, and Abbreviations and Acronyms}

\section{Conversion Factors}

Inch/Pound to SI

\begin{tabular}{lcl}
\hline & Multiply & \multicolumn{1}{c}{ To obtain } \\
\hline inch (in.) & Length & \\
foot (ft) & 2.54 & centimeter $(\mathrm{cm})$ \\
mile (mi) & 0.3048 & meter $(\mathrm{m})$ \\
\hline & 1.609 & kilometer $(\mathrm{km})$ \\
\hline acre & Area & \\
\hline & 0.004047 & square kilometer $\left(\mathrm{km}^{2}\right)$ \\
\hline gallon (gal) & Volume & \\
\hline & 3.785 & liter $(\mathrm{L})$ \\
\hline cubic foot per second $\left(\mathrm{ft}^{3} / \mathrm{s}\right)$ & Flow rate & \\
\hline
\end{tabular}

SI to Inch/Pound

\begin{tabular}{lcl}
\hline \multicolumn{1}{c}{ Multiply } & By & \multicolumn{1}{c}{ To obtain } \\
\hline centimeter $(\mathrm{cm})$ & Length & \\
micrometer $(\mu \mathrm{m})$ & 0.3937 & inch (in.) \\
millimeter $(\mathrm{mm})$ & 0.003937 & inch (in.) \\
meter (m) & 0.03937 & inch (in.) \\
kilometer $(\mathrm{km})$ & 3.281 & foot (ft) \\
& 0.6214 & mile (mi) \\
\hline milliliter $(\mathrm{mL})$ & Volume & \\
liter (L) & 0.03382 & ounce, fluid (fl. oz) \\
& 0.2642 & gallon (gal) \\
\hline milliliter per minute (mL/min) & Flow rate & \\
liter per second (L/sec) & 0.0002642 & gallon per minute (gpm) \\
\hline & 0.2642 & gallon per minute (gpm) \\
\hline gram (g) & Mass & \\
kilogram (kg) & 0.03527 & ounce, avoirdupois (oz) \\
metric ton & 2.205 & pound avoirdupois (lb) \\
\hline
\end{tabular}




\section{Conversion Factors, Datum, and Abbreviations and Acronyms}

\section{Conversion Factors}

\begin{tabular}{ll}
\hline \multicolumn{1}{c}{ Mass concentration unit } & \multicolumn{1}{c}{ Equals } \\
\hline $\begin{array}{l}\text { gram per kilogram }(\mathrm{g} / \mathrm{kg}) \\
\text { milligram per kilogram }(\mathrm{mg} / \mathrm{kg})\end{array}$ & part per thousand \\
microgram per kilogram $(\mu \mathrm{g} / \mathrm{kg})$ & part per million $(\mathrm{ppm})$ \\
nanogram per kilogram $(\mathrm{ng} / \mathrm{kg})$ & part per billion $\left(\mathrm{ppb}, 10^{9}\right)$ \\
\hline \multicolumn{1}{c}{ Liquid concentration unit } & part per trillion (ppt, $\left.10^{12}\right)$ \\
\hline gram per liter $(\mathrm{g} / \mathrm{L})$ & \multicolumn{1}{c}{ Equals } \\
milligram per liter $(\mathrm{mg} / \mathrm{L})$ & part per thousand \\
nanogram per liter $(\mathrm{ng} / \mathrm{L})$ & part per million (ppm) \\
picogram per liter $(\mathrm{pg} / \mathrm{L})$ & part per trillion (ppt, $\left.10^{12}\right)$ \\
\hline
\end{tabular}

Temperature in degrees Celsius $\left({ }^{\circ} \mathrm{C}\right)$ may be converted to degrees Fahrenheit $\left({ }^{\circ} \mathrm{F}\right)$ as follows:

$$
{ }^{\circ} \mathrm{F}=\left(1.8 x^{\circ} \mathrm{C}\right)+32 .
$$

Specific conductance is given in microsiemens per centimeter at 25 degrees Celsius $\left(\mu \mathrm{S} / \mathrm{cm}\right.$ at $\left.25^{\circ} \mathrm{C}\right)$.

Turbidity is given in Nephelometric Turbidity Units (NTU).

Concentrations of chemical constituents in water are given either in milligrams per liter (mg/L) or micrograms per liter $(\mu \mathrm{g} / \mathrm{L})$.

\section{Datum}

Gage height is referenced to the National Geodetic Vertical Datum of 1929 (NGVD 1929).

\section{Abbreviations and Acronyms}

$\begin{array}{ll}\text { ADCP } & \text { acoustic Doppler current profiler } \\ \text { ARI } & \text { Analytical Resources, Inc. } \\ \text { AXYS } & \text { AXYS Analytical Services, Ltd. } \\ \text { BCM } & \text { Bed Composition Model } \\ \text { CPAHs } & \text { carcinogenic polycyclic aromatic hydrocarbons } \\ \text { CVO } & \text { U.S. Geological Survey Cascades Volcano Observatory Sediment Laboratory } \\ \text { DL } & \text { detection limit } \\ \text { Ecology } & \text { Washington State Department of Ecology } \\ \text { EDI } & \text { equal-discharge increment } \\ \text { EMPC } & \text { estimated maximum possible concentration } \\ \text { EPA } & \text { U.S. Environmental Protection Agency } \\ \text { HPAH } & \text { high molecular-weight polycyclic aromatic hydrocarbons }\end{array}$




\title{
Conversion Factors, Datum, and Abbreviations and Acronyms
}

\author{
Abbreviations and Acronyms

$\begin{array}{ll}\text { HRMS } & \text { high-resolution mass spectrometry } \\ \text { LDW } & \text { Lower Duwamish Waterway } \\ \text { LPAH } & \text { low molecular-weight polycyclic aromatic hydrocarbons } \\ \text { LRMS } & \text { low-resolution mass spectrometry } \\ \text { PAHs } & \text { polycyclic aromatic hydrocarbons } \\ \text { PCBs } & \text { polychlorinated biphenyls } \\ \text { PSD } & \text { particle-size distribution } \\ \text { PSRM } & \text { Puget Sound Reference Material } \\ \text { RKM } & \text { river kilometer } \\ \text { RL } & \text { reporting limit } \\ \text { SSC } & \text { suspended-sediment concentration } \\ \text { STM } & \text { Sediment Transport Model } \\ \text { TEO } & \text { toxic equivalent } \\ \text { TOC } & \text { total organic carbon } \\ \text { USGS } & \text { U.S. Geological Survey } \\ \text { VOCs } & \text { volatile organic compounds }\end{array}$





\title{
Data Compilation for Assessing Sediment and Toxic Chemical Loads from the Green River to the Lower Duwamish Waterway, Washington
}

\author{
By Kathleen E. Conn and Robert W. Black
}

\begin{abstract}
Between February and June 2013, the U.S. Geological Survey collected representative samples of whole water, suspended sediment, and (or) bed sediment from a single strategically located site on the Duwamish River, Washington, during seven periods of different flow conditions. Samples were analyzed by Washington-State-accredited laboratories for a large suite of compounds, including polycyclic aromatic hydrocarbons and other semivolatile compounds, polychlorinated biphenyl Aroclors and the 209 congeners, metals, dioxins/furans, volatile organic compounds, pesticides, butyltins, hexavalent chromium, and total organic carbon. Chemical concentrations associated with bulk bed sediment $(<2 \mathrm{~mm})$ and fine bed sediment $(<62.5 \mu \mathrm{m})$ fractions were compared to chemical concentrations associated with suspended sediment. Bulk bed sediment concentrations generally were lower than fine bed sediment and suspendedsediment concentrations. Concurrent with the chemistry sampling, additional parameters were measured, including instantaneous river discharge, suspended-sediment concentration, sediment particle-size distribution, and general water-quality parameters. From these data, estimates of instantaneous sediment and chemical loads from the Green River to the Lower Duwamish Waterway were calculated.
\end{abstract}

\section{Introduction}

The Lower Duwamish Waterway (LDW) is the final 8-km reach of the Green/Duwamish River as it enters Elliott Bay, Puget Sound in Seattle, Washington (fig. 1) and is the site of intense current and historical anthropogenic influence that has resulted in contaminated sediments. Land uses include numerous residential, industrial, and commercial activities such as airplane parts manufacturing, boat manufacturing, concrete manufacturing, food processing, and marinas. In 2001-02, the U.S. Environmental Protection Agency (EPA) and the Washington State Department of Ecology (Ecology) required remedial investigations and feasibility studies on the 8-km-long, $1.8 \mathrm{~km}^{2}$ LDW under the Federal Superfund law and Washington's Model Toxics Control Act because of concern about human health risks from exposure to contaminated sediments. The main contaminants of concern for human health include polychlorinated biphenyls (PCBs), dioxins/furans, carcinogenic polycyclic aromatic hydrocarbons (cPAHs), and arsenic. Additionally, approximately 47 compounds (including individual metals, polycyclic aromatic hydrocarbons [PAHs], phthalates, and other volatile and semivolatile organic compounds) have numeric criteria in Ecology's Sediment Management Standards for protection of the benthic community. Five locations with highly contaminated sediment were identified for early cleanup, and those cleanup activities are completed or near completion (with a target completion date of 2015). The EPA's proposed cleanup plan for the remaining areas was released in early 2013 and includes using combinations of dredging, capping, natural recovery, enhanced natural recovery, and treatment.

To support the implementation of a cleanup plan of contaminated sediments in the LDW, Ecology is leading source control activities to identify sources of sediment recontamination adjacent to and upstream of the LDW. The three major sources of sediment to the LDW were identified as re-suspended bed sediment within the LDW, lateral sources from land adjacent to the LDW, and upstream sources that are transported by the Green River to the Duwamish River/ LDW. The river changes names from the Green River to the Duwamish River at the Black River confluence at river kilometer (RKM) 18. The Sediment Transport Model (STM) developed for the LDW predicts that every year more than 185,000 metric tons of sediment enters the LDW, and that greater than 99 percent of that originates from upstream sources, while approximately 0.5 percent originates from lateral sources and 0.2 percent originates from bed sediment within the LDW (Lower Duwamish Waterway Group, 2008). Additionally, the STM predicts that approximately 90 percent of the total bed area in the LDW receives $10 \mathrm{~cm}$ of new sediment within 10 years or less. Therefore, the sediment and contaminant transport and loading dynamics from the Green River to the LDW will determine, in large part, the sediment recovery potential of remediated areas in the LDW. 


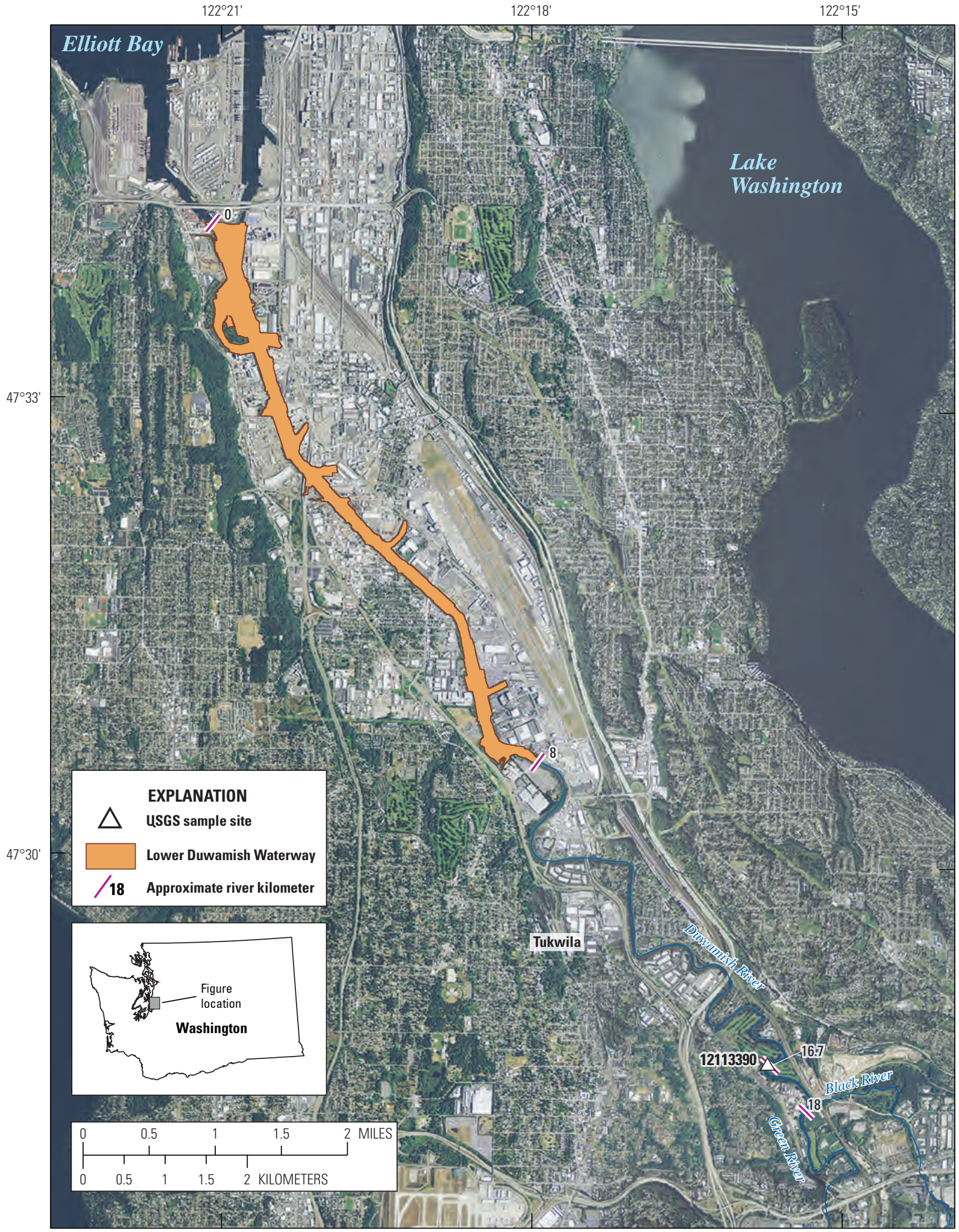

2013 NAIP (National Agricultural Imagery Program) 1 meter imagery, USDA's Farm Service Agency,

Washington State Plane South, NAD83

Figure 1. Location of U.S. Geological Survey (USGS) sampling station relative to the Lower Duwamish Waterway, Seattle, Washington. 
Limited field data are available regarding sediment and contaminant transport and loading dynamics from the Green River to the LDW. The STM estimated suspended- and bedsediment loading into the LDW from upstream sources using grain size information and a flow-rating curve for the Green River based on discharge data from 1960-80 and 1996-98. That physical model was then coupled with contaminantconcentration data to create a Bed Composition Model (BCM). The discharge data used was from a USGS streamgaging station located in Auburn, Washington, more than 40 RKM upstream of the LDW. It was acknowledged that flows at that station were approximately 10 percent less than actual flows into the LDW because of additional inputs between the station and the LDW. This resulted in estimated sediment loads that may have underestimated actual values by 20-25 percent (Lower Duwamish Waterway Group, 2008). The upstream contaminant data was extrapolated from five historical data sets from King County, Washington, Ecology, and the U.S. Army Corps of Engineers. Only one of those data sets (Gries and Sloan, 2009) measured contaminants in suspended sediment (the other studies measured surface sediment or whole water). However, the sample size of the Gries and Sloan data set was relatively small $(n=7)$, and none of the samples were collected during the rising limb of high flow periods. It is hypothesized that a disproportionately large amount of chemical loading from upstream sources to the LDW may occur during the rising limb of storm periods, especially following a period of dry weather. The upstream data that were used in the BCM primarily originated from surface bed-sediment data, and it was acknowledged that those values were estimates of actual contaminant concentrations because the suspended-sediment fraction was not fully represented. Additionally, suspended-sediment-associated chemical loadings are expected to be affected by a number of factors, including antecedent precipitation, streamflow, seasonality, suspended-sediment concentration, sediment organic carbon content, and particle-size distribution. Better estimates of annual sediment loading and toxic chemical loading from suspended sediment in the Green River to the LDW are needed based on concurrent, representative measurements of streamflow, suspended-sediment concentration, and suspended-sediment chemistry collected over a range of conditions at a location close to the LDW upper boundary. These results will improve our understanding of the potential for recontamination of recently remediated sediment within the LDW.

The Duwamish/Green River basin is nearly flat and its tidal influence extends year-round more than $19 \mathrm{~km}$ upstream from the river mouth and during low-flow conditions at least $27 \mathrm{~km}$ upstream. The upstream boundary of the LDW, as determined by the Lower Duwamish Superfund Site (Lower Duwamish Waterway Group, 2012), is at RKM 8, therefore, is in estuarine conditions with very strong tidal influences. The sole location of operation for this study was USGS water quality station: Duwamish River at Golf Course at Tukwila,
Washington; USGS Site 12113390 (figs. 1 and 2). This sampling area had a private bridge that facilitated access to the river. This sampling station is located at approximately RKM 16.7, which is tidally influenced but non-estuarine. The selection of this sampling station minimized the potential for collection of suspended sediment that could have originated from the LDW and been re-suspended and transported upstream during high tides. Development along the river between the upper boundary of the LDW (RKM 8) and the sampling station (RKM 16.7) includes the golf course, a small commercial complex, and residential properties. The contaminant contributions to the river from this reach, which were not captured in this study, primarily consist of stormwater outfalls.

\section{Purpose and Scope}

This report presents data from sampling of whole water, suspended sediment, and bed sediment at a station on the Duwamish River upstream of the LDW between February and June 2013. Whole-water, suspended-sediment, and bedsediment samples were analyzed for PAHs, PCBs, dioxins/ furans, metals, other semivolatile organic compounds, volatile organic compounds (VOCs), pesticides, butyltins, hexavalent chromium, total organic carbon (TOC), and particle-size distribution (PSD, for sediment samples only). Field measurements were made of temperature, $\mathrm{pH}$, specific conductance, dissolved oxygen, and turbidity. The chemical results, coupled with measurements of instantaneous streamflow and suspended-sediment concentration (SSC), provide preliminary estimates of instantaneous sediment and chemical loads associated with upstream sources in the Green River to the LDW.

\section{Methods}

\section{Field Sampling and Processing}

Between February and June 2013, seven bridge-based sampling periods were conducted over a range of precipitation and flow conditions targeting high flows. Additionally, six boat-based sampling periods were conducted during low-flow conditions. Real-time stage and discharge measurements from upstream USGS gaging stations were used to inform sampling. To minimize tidal backwater effects (that could transport sediment upstream), samples were collected during a 6-hour window surrounding low tide. During each bridge-based sampling period, five tasks occurred to measure instantaneous discharge, general water quality, water chemistry, suspendedsediment physical parameters, and suspended-sediment chemistry. Additionally, bed-sediment chemistry was measured during each boat-based sampling period. A summary of these tasks is contained in table 1. 


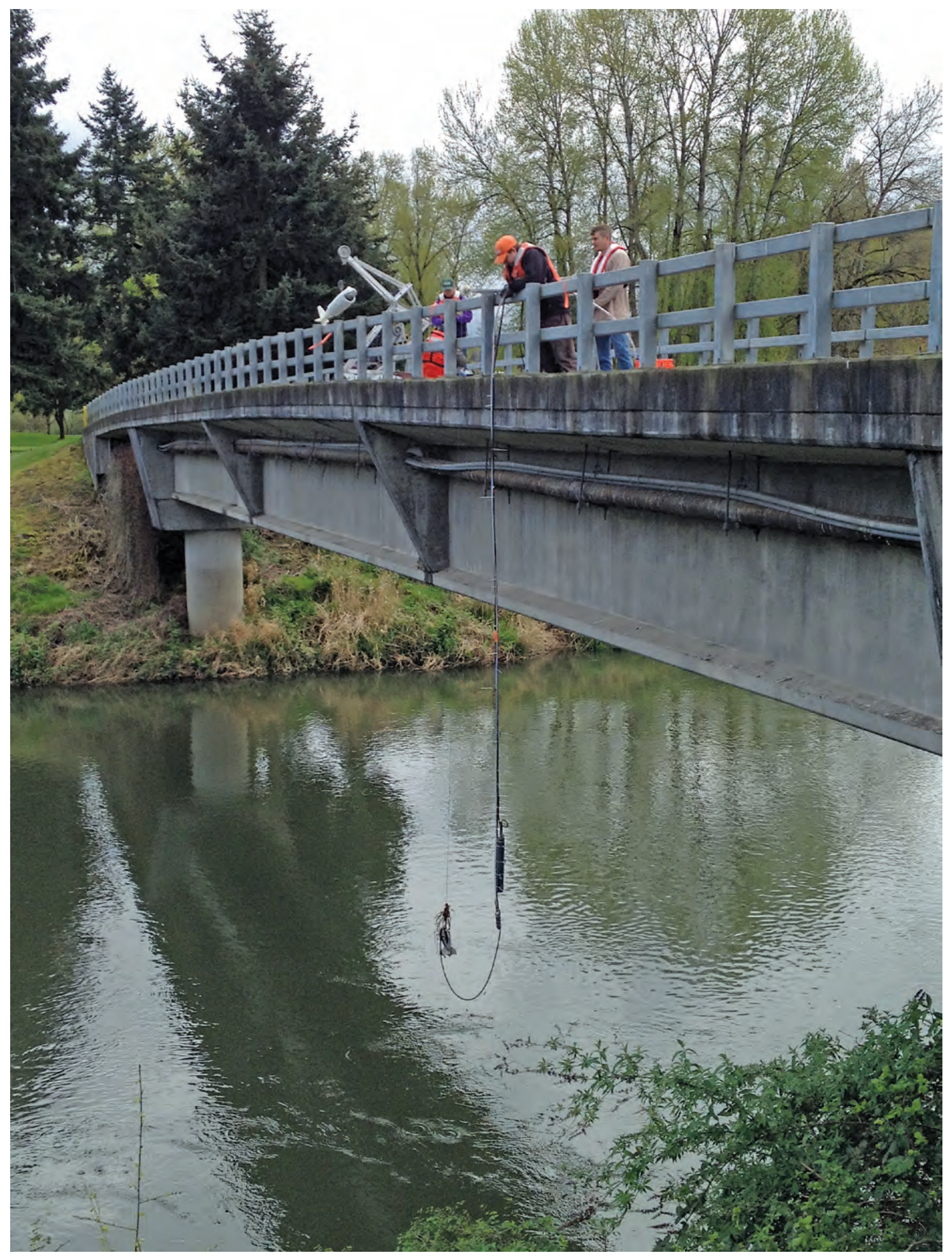

Figure 2. Selected sampling station, Duwamish River at Golf Course at Tukwila, Washington (12113390), located at river kilometer 16.7. 
Methods 5

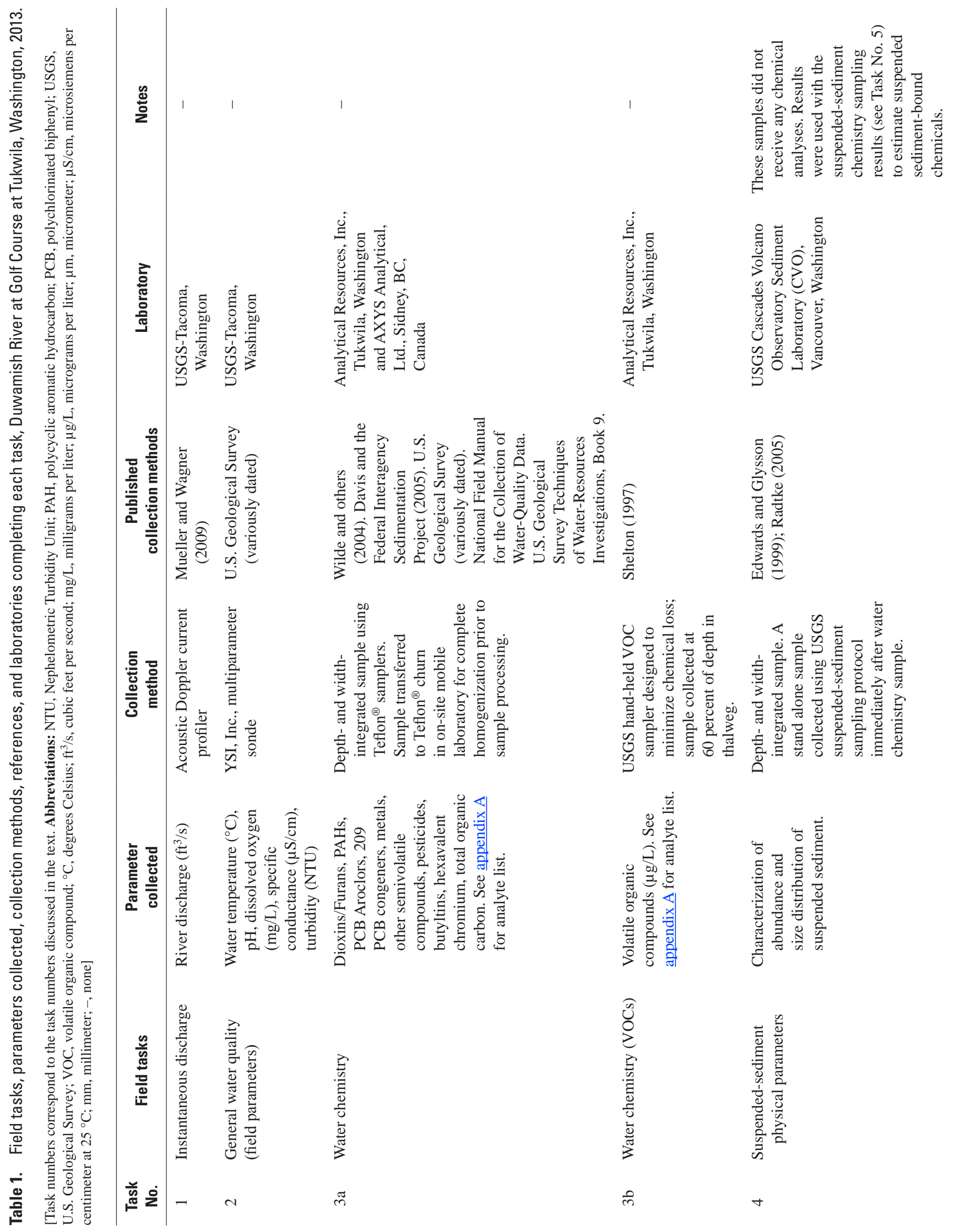




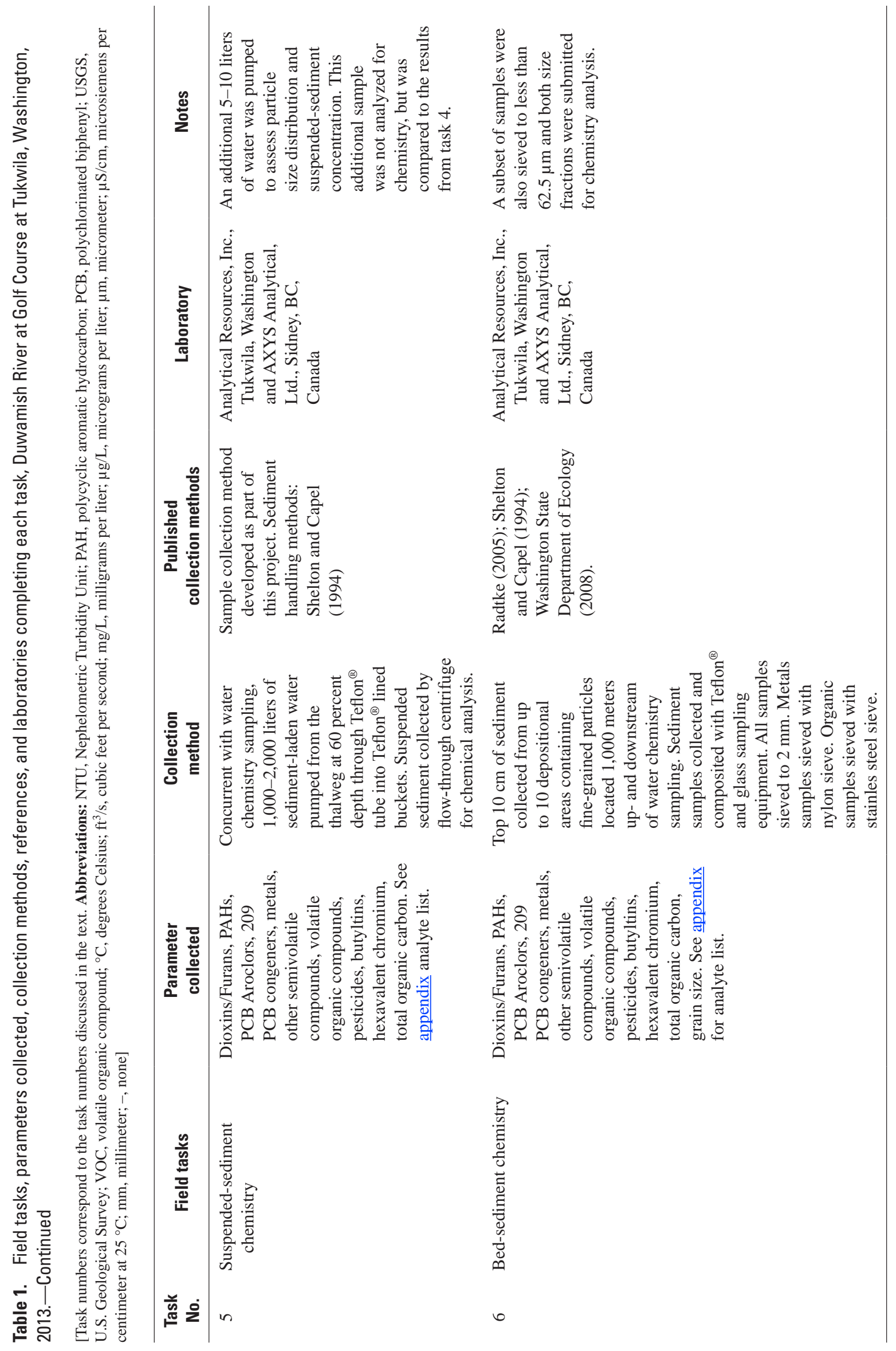


- Task 1 (instantaneous discharge): River discharge was measured using an acoustic Doppler current profiler (ADCP) following standard USGS protocols (Mueller and others, 2009).

- Task 2 (general water quality): Water-quality parameters (water temperature, $\mathrm{pH}$, dissolved oxygen, specific conductance, and turbidity) were measured using a multiparameter sonde. During the first two sampling periods, water quality parameters were measured at each of the five cross-section stations (see tasks 3 and 4), and it was found that the cross-section was well-mixed. During the remaining sampling periods, the sonde was co-located with the pump intake (see task 5).

- Task 3 (water chemistry): Based on the discharge measurements, the river cross-section was divided into five equal discharge increments (EDIs) for water chemistry analysis and suspended-sediment physical parameter analysis (see task 4) using standard USGS protocols (U.S. Geological Survey, variously dated). This sampling technique collects a flow-weighted, depth-integrated sample that is representative of the entire river cross-section at that sampling site. Briefly, a sampler is lowered at a consistent transit rate from the surface to the bottom and back to the surface of the water column at each of the five stations. The process was repeated until necessary sample volume was obtained. Water samples were collected from each cross section station in 3-L Teflon ${ }^{\circledR}$ bags using an approved D-96 sampler (Davis and Federal Interagency Sedimentation Project, 2005). The water samples were composited in a 14-L Teflon ${ }^{\circledR}$ churn and immediately processed in an on-site mobile laboratory. In the mobile laboratory, the composited water sample was churned according to USGS protocols (U.S. Geological Survey, variously dated) to ensure sample homogenization prior to bottle filling.

Volatile organic compounds were collected separately using a USGS designed and tested hand-held sampler to avoid losses resulting from sample pouring, transferring, and churning (Shelton, 1997). The sampler, containing up to four $40 \mathrm{~mL}$ glass vials, was lowered to a mid-point in the vertical water column at a single station in the centroid of flow. Water filled the bottle slowly from the bottom to avoid turbulence and head space that could result in analyte losses. All bottled samples were stored on ice and transported within 6 hours to Analytical Resources, Inc. (ARI) in Tukwila, Washington. Samples for high-resolution mass spectrometry (HRMS) analysis were then shipped from ARI to AXYS Analytical Services, Ltd. (AXYS), while the remaining analyses were done by ARI.
- Task 4 (suspended-sediment physical parameters): After completion of the water chemistry sampling, a second cross section of depth- and width-integrated sampling was completed to characterize the abundance and size distribution of suspended sediment using standard USGS protocols (Edwards and Glysson, 1999; Radke, 2005). Using the same EDI sampler as was used in task 3 , water was collected in multiple 3-L polyethylene bags. The volume of water collected depended on current sediment conditions and ranged between 5 and $15 \mathrm{~L}$ (one to three bags per station). The samples were transported to the USGS Cascades Volcano Observatory (CVO) in Vancouver, Washington for analysis of SSC and PSD.

- Task 5 (suspended-sediment chemistry): Concurrent with tasks 3 and 4 , river water was pumped from a point source through Teflon ${ }^{\circledR}$ tubing into sequential buckets lined with Teflon ${ }^{\circledR}$ bags for suspendedsediment chemistry analysis. Various pumps were tested throughout the project, including a peristaltic pump and two types of submersible pumps. The pump intake was located approximately 0.6 times the depth in the thalweg. On sampling days when large floating debris was present, the pump intake was located midchannel out of the debris path. The volume of water collected depended on the current sediment conditions, and ranged between 1,000 and 2,000 L. During lowflow/low-turbidity sampling periods, when more than $1,000 \mathrm{~L}$ of water was needed for sufficient suspendedsediment sample, a second station visit occurred at low tide on the day before or after to collect additional water to composite with the first 1,000 L. The samplefilled Teflon ${ }^{\circledR}$ bags were sealed for transport. At the Washington Water Science Center Field Services Unit located in Tacoma, Washington, the water and sediment from the Teflon ${ }^{\circledR}$ bags were pumped into parallel continuous flow-through centrifuges to concentrate the suspended sediment. Water samples were pumped from the bags into the centrifuges using Teflon ${ }^{\circledR}$ tubing, C-FLEX tubing, and a peristaltic pump at a flow rate of $200-300 \mathrm{~mL} / \mathrm{min}$ to maximize sediment recovery. Pre-centrifuged water in buckets was kept at $4{ }^{\circ} \mathrm{C}$ until centrifugation, which typically required 24-48 hours. Concentrated sediment and the overlying water from the centrifuge bowl (approximately $300 \mathrm{~mL}$ per bowl) was composited in a glass jar and stored quiescently at $4{ }^{\circ} \mathrm{C}$. After as many as 72 hours of settling, sediment was still suspended in the overlying water. The overlying water was carefully removed by pipette and filtered through pre-weighed $0.3 \mu \mathrm{m}$ nominal pore size glass fiber filters. Two to six filters were required per sampling period to filter the overlying water. The filters and sediment samples were shipped on ice to ARI. 
- Task 6 (bed-sediment chemistry): A bed-sediment sample was collected during six low-flow, low tide conditions when depositional areas were exposed along the river bank. Samples were collected according to modified Ecology and USGS protocols (Shelton and Capel, 1994; Radke, 2005; Washington State Department of Ecology, 2008) for analysis of the same suite of chemical parameters as the suspendedsediment samples (see table 1) and PSD. Briefly, sub-samples (0-10 cm depth) from as much as 10 locations marked by geographic information systems within 1,000 $\mathrm{m}$ upstream (during the first two periods) or 1,000 $\mathrm{m}$ downstream (during the remaining four periods) of the bridge were composited into a single sample during each period. Locations were selected to focus on areas with a high deposition of fine material. Immediately after sample collection, the composited sample was homogenized using a Teflon ${ }^{\circledR}$ spatula in an on-site mobile laboratory. The sediment was wet sieved with a Teflon ${ }^{\circledR}$ spatula through a $2 \mathrm{~mm}$ diameter sieve prior to jar filling. Samples for metals analysis were processed through a plastic sieve, and samples for organic analyses were processed through a stainless steel sieve. During the final three sampling periods, the composited slurry was also wet sieved with a Teflon ${ }^{\circledR}$ spatula through a $62.5 \mu \mathrm{m}$ diameter sieve and collected into separate jars for analysis to compare chemistry results from the bulk bed sediment $(<2 \mathrm{~mm})$ to results from the fine bed sediment $(<62.5 \mu \mathrm{m})$. Overlying water from the wet sieving procedure $(<300 \mathrm{~mL})$ was decanted from the jars and discarded prior to chemical analysis. A summary of sampling dates and completed tasks is given in table 2 .

\section{Analytical Methods}

Samples of water (task 3), suspended sediment (task 5), and bed sediment (task 6) were analyzed for a suite of chemical and physical parameters using EPA-approved and (or) USGS-approved methods by ARI, AXYS, and CVO. Table 3 lists parameter group, method, and analyzing laboratory. A complete list of analytes for each media is contained in the appendix tables. During low-turbidity sampling periods, even with consecutive days of water collection, there was insufficient suspended-sediment concentrated from the centrifuge to analyze for all parameters. In those cases, only prioritized analyses were conducted for dioxins/furans, PCB congeners, metals, PAHs, and TOC. The $0.3 \mu \mathrm{m}$ filters from the centrifuge decant water were composited with an aliquot of suspended sediment and extracted together for dioxins/furans and PCB congeners only. The dry weight of the filter was subtracted from the total sample weight to determine a concentration per dry sediment. The remaining chemical analytes were analyzed in a separate sediment sample (with no filter).

\section{Quality Assurance and Quality Control}

USGS quality assurance procedures for surface-water measurements and water-quality sampling and analysis were followed (Wagner and others, 2007; U.S. Geological Survey, variously dated). These procedures included proper equipment selection, cleaning procedures, and sampling protocols for low level organic compounds, VOCs, and metals. Sampling equipment for chemical analyses was made of Teflon ${ }^{\circledR}$ that had been pre-cleaned with phosphate-free soap, rinsed three times with tap water, soaked in 5 percent hydrochloric acid, rinsed with deionized water, rinsed with high purity methanol, and air dried. Field sampling techniques included various measures to avoid sample contamination, including the "clean hands, dirty hands" technique and processing of water samples in a clean mobile laboratory. Hydrologists and hydrologic technicians on this project had been trained at the USGS National Training Center in the collection of water-quality samples, including samples for trace organic and low level mercury analyses.

Included in each of the seven sampling periods was a trip blank for VOCs ("trip blank") in which a sample of deionized water filled in a VOC vial at the laboratory conducting the analysis was transported in the cooler to and from the site during field sampling. Other quality control samples for chemistry analysis, listed by date in table 2 , included:

- One field equipment blank sample of water ("field blank"), in which organic-free blank water was transported in its original container in the mobile laboratory to the field site where it was poured into the pre-cleaned Teflon ${ }^{\circledR}$ churn, churned, and filled into sample bottles in the mobile laboratory.

- One field replicate of water ("field replicate"), in which a second sample was collected at each EDI station immediately following the first sample and composited in a second pre-cleaned Teflon ${ }^{\circledR}$ churn.

- One centrifuge equipment blank sample of suspended sediment ("equipment blank"), in which an environmental sediment sample that had been burned in a muffle furnace at $450{ }^{\circ} \mathrm{C}$ for 6 hours, was mixed with organic-free blank water to form a slurry. The slurry was pumped and processed through all of the field and lab equipment for suspended-sediment sampling (that is, Teledyne Isco pump, Teflon ${ }^{\circledR}$ tubing, Teflon ${ }^{\circledR}$ bag, Teflon ${ }^{\circledR}$ tubing, centrifuge bowl, and glass jar).

- One centrifuge source sediment sample ("source blank"), in which the environmental sediment sample that had been burned in a muffle furnace at $450{ }^{\circ} \mathrm{C}$ for 6 hours, was directly placed into a sample jar for analysis.

- One field split of bed sediment ("field split"), in which the sieved, homogenized material was split into two sample jars for analysis. 
Table 2. Field tasks and sampling dates at Duwamish River at Golf Course at Tukwila, Washington, 2013.

[A trip blank for volatile organic compounds was included with each water chemistry sample. Abbreviations: X, task was completed on that date; -, task not completed on that date; TOC, total organic carbon; PSRM, Puget Sound Reference Material; <, less than; mm, millimeter; $\mu$ m, micrometer]

\begin{tabular}{|c|c|c|c|c|c|c|c|c|}
\hline \multirow{2}{*}{$\begin{array}{l}\text { Task } \\
\text { No. }\end{array}$} & \multirow{2}{*}{ Field tasks } & \multicolumn{7}{|c|}{ Sampling date } \\
\hline & & 02-07-2013 & 03-13-2013 & 04-05-2013 & 04-08-2013 & 04-29-2013 & 05-13-2013 & 06-19-2013 \\
\hline 1 & $\begin{array}{l}\text { Instantaneous } \\
\text { discharge }\end{array}$ & $\mathrm{X}$ & $\mathrm{X}$ & $\mathrm{X}$ & $\mathrm{X}$ & $\mathrm{X}$ & $\mathrm{X}$ & $\mathrm{X}$ \\
\hline 2 & $\begin{array}{l}\text { General water } \\
\text { quality (field } \\
\text { parameters) }\end{array}$ & $\mathrm{X}$ & $\mathrm{x}$ & $\mathrm{X}$ & $\mathrm{x}$ & $\mathrm{X}$ & $\mathrm{X}$ & - \\
\hline 3а & Water chemistry & $\mathrm{X}$ & $\mathrm{X}$ & $\mathrm{X}$ & $\mathrm{x}$ & $\begin{array}{c}\mathrm{X} \\
\text { (plus field } \\
\text { replicate) }\end{array}$ & $\begin{array}{c}\text { X, } \\
\text { metals, } \\
\text { TOC only } \\
\text { (plus field } \\
\text { blank) }\end{array}$ & $\begin{array}{c}\text { X, } \\
\text { metals, } \\
\text { TOC only }\end{array}$ \\
\hline $3 b$ & $\begin{array}{l}\text { Water chemistry } \\
\text { (volatile organic } \\
\text { compounds) }\end{array}$ & $\mathrm{X}$ & $\mathrm{x}$ & $\mathrm{X}$ & $\mathrm{x}$ & $\begin{array}{c}\text { X } \\
\text { (plus field } \\
\text { replicate) }\end{array}$ & $\begin{array}{c}\text { X } \\
\text { (field blank } \\
\text { only) }\end{array}$ & - \\
\hline 4 & $\begin{array}{c}\text { Suspended- } \\
\text { sediment } \\
\text { physical } \\
\text { parameters }\end{array}$ & $\mathrm{X}$ & $\mathrm{X}$ & $\mathrm{X}$ & $\mathrm{X}$ & - & $\mathrm{X}$ & $\mathrm{X}$ \\
\hline 5 & $\begin{array}{l}\text { Suspended- } \\
\text { sediment } \\
\text { chemistry }\end{array}$ & $\mathrm{X}$ & $\begin{array}{c}\mathrm{X}, \\
\text { composited } \\
\text { with } \\
03-14-13\end{array}$ & $\begin{array}{c}\text { X, } \\
\text { composited } \\
\text { with } \\
\text { 04-04-13 } \\
\text { (plus } \\
\text { equipment } \\
\text { blank and } \\
\text { source blank) }\end{array}$ & $\begin{array}{c}\mathrm{X}, \\
\text { composited } \\
\text { with } \\
04-07-13\end{array}$ & - & $\mathrm{X}$ & - \\
\hline \multirow{2}{*}{$\begin{array}{l}\text { Task } \\
\text { No. }\end{array}$} & \multirow{2}{*}{ Field tasks } & \multicolumn{6}{|c|}{ Sampling date } & \\
\hline & & 02-26-2013 & 03-29-2013 & $04-26-2013$ & 05-09-2013 & 05-31-2013 & 06-21-2013 & \\
\hline 6 & $\begin{array}{l}\text { Bed-sediment } \\
\text { chemistry }\end{array}$ & $\mathrm{X}$ & $\mathrm{x}$ & $\begin{array}{c}\text { X } \\
\text { (plus field } \\
\text { split and } \\
\text { PSRM) }\end{array}$ & $\begin{array}{c}\text { X } \\
\text { (plus } \\
<62.5 \mu \mathrm{m} \\
\text { sample) }\end{array}$ & $\begin{array}{c}\text { X } \\
\text { (plus } \\
<62.5 \mu \mathrm{m} \\
\text { sample) }\end{array}$ & $\begin{array}{c}\text { X } \\
\text { (plus } \\
<62.5 \mu \mathrm{m} \\
\text { sample) }\end{array}$ & \\
\hline
\end{tabular}

- One Puget Sound Reference Material (PSRM), which is a regionally-relevant sediment standard reference material for dioxins/furans, PCB congeners, and PCB Aroclors, was analyzed for dioxins/furans, PCB congeners, PCB Aroclors and total organic carbon by the corresponding laboratories. Laboratory results were compared to the average concentration of the standard as determined during previous round robin laboratory testing.
Both analytical laboratories conducted laboratory blank, replicate, and matrix spike analyses according to their quality-assurance and quality-control plan (that is, with every batch of approximately 20 samples). If values exceeded control limits then corrective actions were taken such as re-runs and re-extractions. Additional details regarding the field and laboratory methods are available in Black and Conn (2013). 
Table 3. Analytical parameter groups, methods, and analyzing laboratory for samples collected at Duwamish River at Golf Course, at Tukwila, Washington, 2013.

[Abbreviations: ARI, Analytical Resources, Inc., Tukwila, Wash.; AXYS, AXYS Analytical, Ltd., Sidney, British Columbia, Canada; CVO, U.S. Geological Survey Cascades Volcano Observatory; EPA, U.S. Environmental Protection Agency; PSEP, Puget Sound Estuary Program; SIM, selected ion monitoring; SM, standard methods]

\begin{tabular}{lll}
\hline \multicolumn{1}{c}{ Analytical parameter } & \multicolumn{1}{c}{ EPA method / reference } & \multicolumn{1}{c}{$\begin{array}{c}\text { Analyzing } \\
\text { laboratory }\end{array}$} \\
\hline Volatile organic compounds & EPA 8260A & ARI \\
Semivolatile compounds & EPA 8270D & ARI \\
Low-level polycyclic aromatic hydrocarbons & EPA 8270D SIM & ARI \\
Polychlorinated biphenyl Aroclors & EPA 8082A & ARI \\
209 polychlorinated biphenyl congeners & EPA 1668A & AXYS \\
Pesticides & EPA 8081B & ARI \\
Dioxins/furans & EPA 1613B & AXYS \\
Trace elements & EPA 200.8 & ARI \\
Low-level mercury & EPA 7470A & ARI \\
Butyltins & Krone and others (1989) & ARI \\
Hexavalent chromium & EPA 7196 (SM 3500 CrD) & ARI \\
Total organic carbon & EPA 415.1 / Plumb (1981) & ARI \\
Total solids & SM 2540B & ARI \\
Suspended-sediment concentration & Guy (1977) & CVO \\
Particle-size distribution (suspended-sediment) & Guy (1977) & CVO \\
Particle-size distribution (bed-sediment) & Puget Sound Estuary Program (1986) & ARI \\
\hline
\end{tabular}

\section{Data Reporting}

Field notes and field parameters measured during each sampling period were reviewed by USGS project managers. An EPA Level 4 data package was produced by the two analytical laboratories for every sample analyzed in this project. Each package included detailed information regarding package completeness, instrument calibration and performance, and instrument output (that is, chromatograms) for confirmation of detections and non-detections. A narrative was provided with each package, documenting any deviations from protocol or problems encountered during analysis. All data packages were reviewed by the project manager at a level comparable to an EPA Level 2 validation, including assessment of precision (replicate analyses), accuracy (compound recovery), and blank contamination. The Level 2 validation identified some minor discrepancies, such as missed flags, which were reported to the laboratory and corrected in a revised data package. A representative subsample of data packages were reviewed by USGS analytical chemists with current organic and inorganic instrument expertise at a level comparable to an EPA Level 4 validation. This included recalculation of results from instrument responses to confirm the correct identification and quantitation of analytes, tentatively-identified compounds, and non-detected compounds. The Level 4 validation identified no major miscalculations by either lab. The Level 2 and Level 4 reviews identified a need to further censor the result qualifiers, which is described in detail in appendix A.

Numerous nearly synonymous terms are used by the laboratories for reporting analytical data based on criteria defined by the EPA or accreditation agencies. For simplicity, detection limit (DL) and reporting limit (RL) are the only two terms used in this report. The DL is defined as the lowest result that can be reliably distinguished from a blank based on historical method blank detections with a false positive rate of less than or equal to 1 percent. For compounds determined by HRMS, including the dioxins/furans and PCB congeners, the DL is defined as the concentration equivalent to three times the estimated chromatographic noise height, determined individually for every sample analysis run. The RL is defined as the lowest concentration that can be reliably achieved within specific limits of precision and accuracy during routine operating conditions. For HRMS compounds, the RL is determined by prorating the concentration of the lowest calibration limit for sample size and extract volume by using:

$$
\begin{aligned}
& \text { ([lowest level calibration standard] } \times \text { [extract volume])/ } \\
& \text { sample size. }
\end{aligned}
$$

Differences between various laboratory and agency protocols for coding analytical data to address measurement considerations and (or) abnormalities are common. 
Adjustments to the laboratory-provided qualifiers from laboratories used in this study were made to be consistent with Ecology's Toxics Cleanup Program data reporting protocols (Washington State Department of Ecology, 2008) as outlined in the EPA Functional Guidelines (U.S. Environmental Protection Agency, 2008, 2009, 2010, 2011). Data that had been flagged or qualified by the laboratory or during the Level 2 or Level 4 review process with qualifiers other than U- and $\mathrm{J}$-containing qualifiers were amended following the protocols described in appendix A.

The complete analytical results are stored in Ecology's publicly-available Environmental Information Management database, including two qualifier columns containing the original lab qualifiers and the USGS-amended qualifiers. The complete analytical results for all individual compounds with USGS-amended qualifiers are presented in the appendix tables. In the "Quality-Assurance Data" and various "Chemistry Data" sections, only detected compounds (after qualifier amendments) are presented, which includes estimated (J-qualified) data. Only results from the more sensitive of the two methods for PAHs are presented. The Aroclor results from both analyzing laboratories are presented for comparison. $\mathrm{J}$-qualified data is included in the summed or calculated values. The following summed and calculated values are presented in the results.

\section{Dioxins/Furans}

- Summed homologues (that is, total tetra-dioxins).

- Total dioxins/furans as a summed concentration of the 17 congeners.

- Total dioxins/furans as a Toxic Equivalent (TEQ) according to the World Health Organization 2005 guidelines (Van den Berg and others, 2006). If a congener was not detected above the detection level, a value of one half of the detection level was used in the calculations.

\section{Polycyclic Aromatic Hydrocarbons}

- Total cPAHs as a summed concentration of benzo(a) anthracene, chrysene, benzo(a)pyrene, indeno(1,2,3c,d)pyrene, dibenz(a,h)anthracene, and total benzofluoranthenes (sum of b-, j-, and k- isomers).
- Total cPAHs as a TEQ according to the potency equivalency factors adopted by the California Environmental Protection Agency (California Environmental Protection Agency, 2005). If a compound was not detected above the detection level, a value of one half of the detection level was used in the calculations.

- Total high molecular weight PAHs (HPAH) as a summed concentration of fluoranthene, pyrene, benz[a] anthracene, chrysene, benzofluoranthene, benzo[b] fluoranthene, benzo[k]fluoranthene, benzo[a]pyrene, indeno[1,2,3-c,d]pyrene, dibenzo[a,h]anthracene, and benzo[g,h,i]perylene.

- Total low molecular weight PAHs (LPAH) as a summed concentration of naphthalene, acenaphthylene, acenaphthene, fluorene, phenanthrene, and anthracene.

\section{Polychlorinated Biphenyls}

- Summed homologues (that is, total monochloro biphenyls).

- Total PCBs as a sum of the 209 congeners.

- Aroclors. Polychlorinated biphenyl results for all environmental and quality assurance samples are reported as a combination of three Aroclors: 1242, 1254, and 1260. The Aroclor concentrations were calculated according to the following equations, in which concentrations of specific congeners are summed and multiplied by a quantification factor:

- Aroclor $1242=(8,18 / 30,20 / 28,31) \times 3.0$

- Aroclor 1254= (83/99, 86/87/97/108/119/125) $\times 8.0$

- Aroclor $1260=(170,180 / 193,183 / 185) \times 5.0$

- Analytical Resources, Inc. also presented PCB detections using EPA Method SW8082 as Aroclors 1242, 1254, and 1260. Though this method is less sensitive than the method used by AXYS for PCB congeners, the detections are presented for inter-lab Aroclor comparison. Analytical Resources, Inc. did not report total PCBs. 
Other than the TEQ calculations (in which a value of one-half of the detection level was used for undetected compounds), only detected concentrations (including J-qualified detections) were included in summed values. If all compounds in a summed calculation were undetected, the total value is represented by the single highest detection level (with a $\mathrm{U}$ or UJ qualifier). All sediment concentrations were reported by the laboratories as a dry weight concentration. Organic carbon-normalized concentrations were calculated by dividing the dry weight concentration by the fraction of TOC in the sample.

Instantaneous chemical loads were estimated using a method based on whole water chemical concentrations and a method based on suspended-sediment chemical concentrations. Instantaneous whole-water chemical loads in grams per hour were calculated using the following equation:

Water Chemical Load $(\mathrm{g} / \mathrm{hr})=\mathrm{C}_{\mathrm{W}}(\mathrm{g} / \mathrm{L}) \times \mathrm{Q}(\mathrm{L} / \mathrm{hr})$

where

$\mathrm{C}_{\mathrm{W}}$ is chemical concentration in whole water in grams per liter;

Q is instantaneous river discharge in liters per hour;

Instantaneous suspended-sediment chemical loads (g/hr) were calculated using the following equation:

Sediment Chemical Load $(\mathrm{g} / \mathrm{hr})=\mathrm{C}_{\mathrm{S}}\left(\mathrm{g} / \mathrm{kg} \times \mathrm{kg} / 10^{6} \mathrm{mg}\right) \times$ Q $(\mathrm{L} / \mathrm{hr}) \times$ SSC $(\mathrm{mg} / \mathrm{L})$

where

$\mathrm{C}_{S}$ is chemical concentration in suspended sediment in gram per kilogram;

Q is instantaneous river discharge in liters per hour; and

SSC is suspended sediment concentration in milligrams per liter.

Non-detects were assigned a zero value for instantaneous loading calculations.

\section{Hydrology and Field Parameter Data}

The seven bridge-based sampling periods for water and (or) suspended sediment occurred over a range of precipitation and streamflow conditions (table 4). The sampling dates are overlayed on the stream gage-height record from the closest continuous streamgage (USGS 12113350 Green River at Tukwila, WA, fig. 3), which is located 3.2 RKM upstream of the sampling bridge (fig. 2). Although sampling periods targeted periods of predicted rainfall, actual rainfall often was less than predicted. Of the seven periods, five were during periods defined in this study as "low precipitation" (72-hour antecedent rainfall $\leq 0.4$ in.). The other two samples were collected during the rising limb (April 5, 2013) and the peak flow (April 8, 2013) of a storm that set a single-day precipitation record of 1.54 in. at nearby Seattle-Tacoma International Airport. In this report, 72-hour antecedent rainfall is defined as the sum of the provisional daily total for the sampling date and 2 previous days from the USGS 12113000 precipitation station, located upstream in the watershed.

Stream gage height at USGS 12113350 at the time of sampling (always during low-tide) ranged from 3.77 to $12.64 \mathrm{ft}$. Measured instantaneous discharge at the sampling site during the time of sample collection ranged from 816 to $4,955 \mathrm{ft}^{3} / \mathrm{s}$. River water temperature increased steadily during the study from $6.29^{\circ} \mathrm{C}$ in February to 11.17 ${ }^{\circ} \mathrm{C}$ in May, with the exception of the storm-peak water temperature, which dipped more than a degree cooler than 2 days prior (table 4). Specific conductance ranged from $55 \mu \mathrm{S} / \mathrm{cm}$ at $25^{\circ} \mathrm{C}(\mu \mathrm{S} / \mathrm{cm})$ during the storm peak to 96 $\mu \mathrm{S} / \mathrm{cm}$ during a low-precipitation period. Turbidity ranged from 2.7 Nephelometric Turbidity Units (NTU) during a low-precipitation period to an average of 20 NTU during the storm-peak sampling (with high sediment pulses exceeding $80 \mathrm{NTU}$ ). Suspended-sediment concentration (SSC), measured using representative discharge-weighted, depth integrated methods, ranged from $6 \mathrm{mg} / \mathrm{L}$ during a low-precipitation period to $81 \mathrm{mg} / \mathrm{L}$ during the storm peak (table 4). The percentage of fines in the suspended sediment ranged from 44 percent during the storm peak to 84 percent during a low-precipitation period (table 4). There was sufficient suspended sediment only during the storm peak to analyze a full particle-size distribution (see results in section, "Comparison of Suspended-Sediment and Bed-Sediment Data”).

All six boat-based bed-sediment sampling periods (fig. 3) occurred when the 72-hour antecedent rainfall was less than $0.2 \mathrm{in}$. The stream gage height at USGS 12113350 (3.2 RKM upstream of the sampling bridge) at the time of sample collection ranged from 3.91 to $8.46 \mathrm{ft}$. 


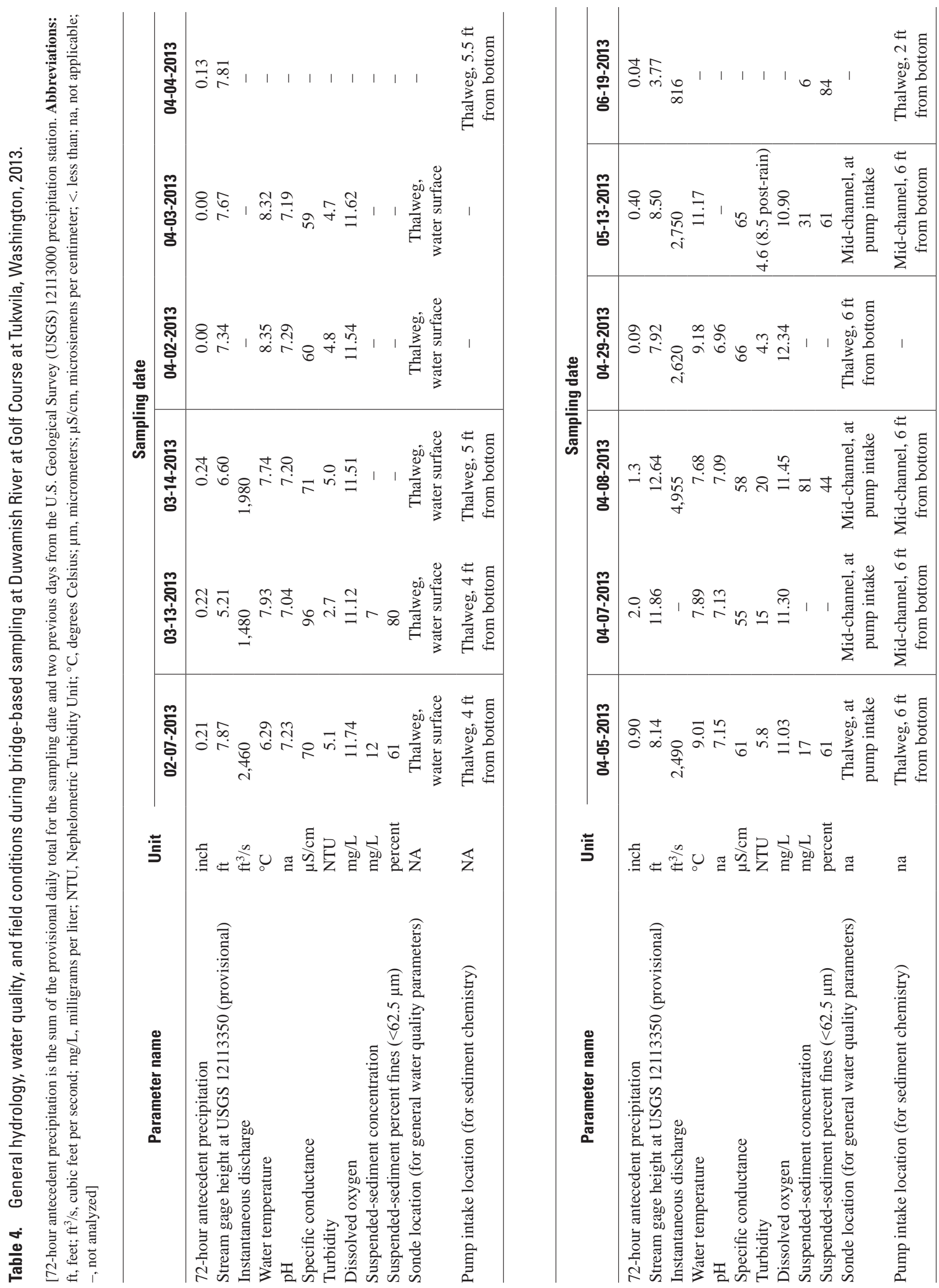




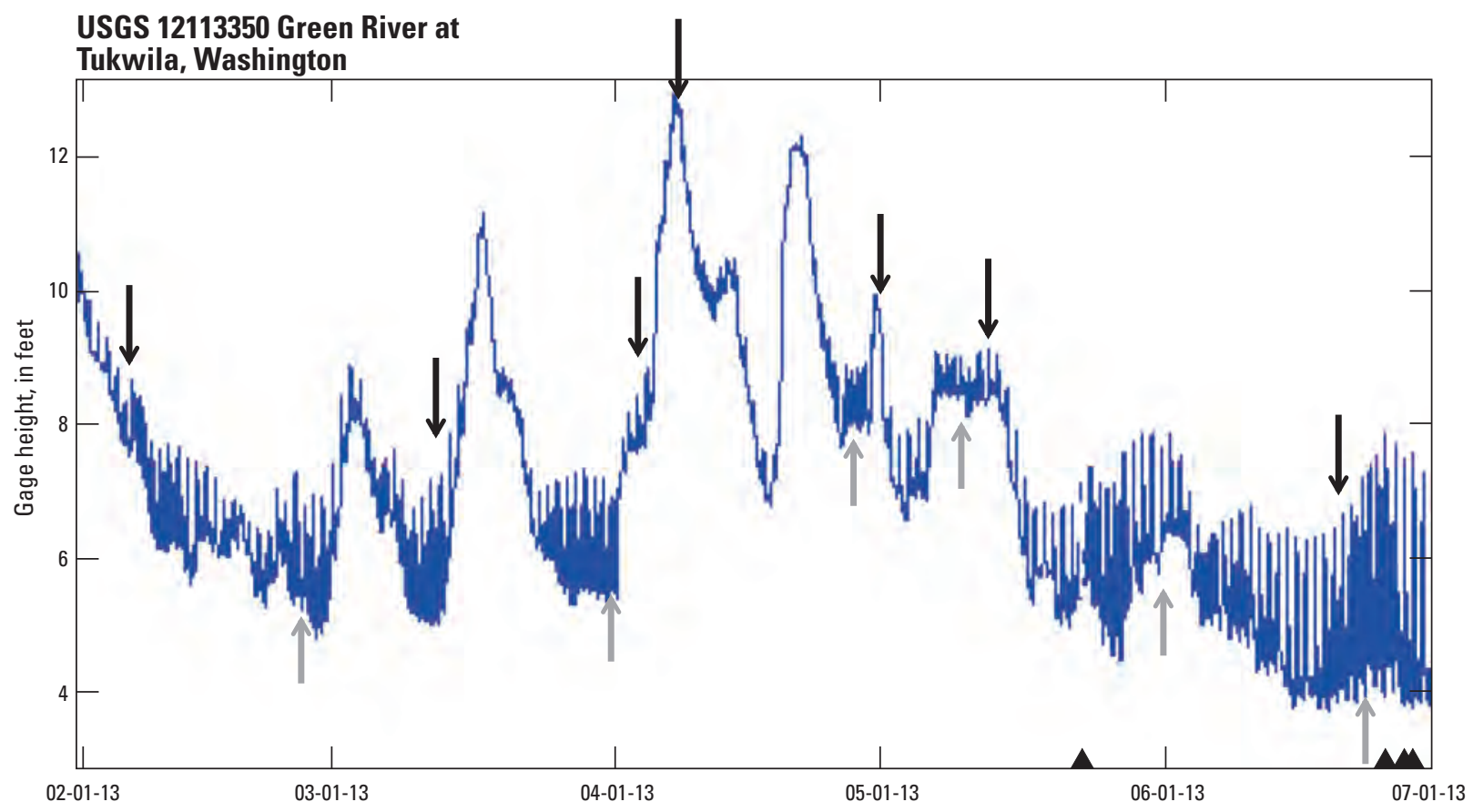

EXPLANATION

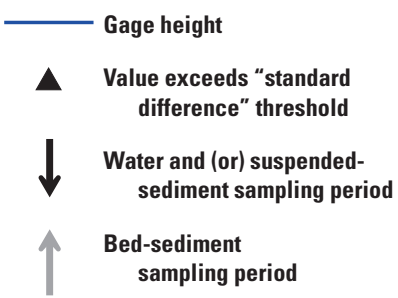

Figure 3. Gage height and suspended- (bridge based) and bed- (boat based) sediment collected at U.S. Geological Survey streamgage 12113350, Green River at Tukwila, Washington, February-July 2013. Sampling site is 3.2 river kilometers upstream of bridge.

\section{Quality-Assurance Data}

There were no detections of VOCs in the five trip blank water samples (see table A2). In the singe field equipment blank water sample, there were no detections of VOCs, metals, PAHs, or other semivolatile organic compounds, pesticides, butylins, hexavalent chromium, or TOCs (see table A2). Dioxins/furans and PCB congeners (table 5) were detected at low levels in the single water field blank sample (total dioxins/furans $=1.05$ picograms, expressed as a toxic equivalent, per liter [pg TEQ/L], J-qualified; total $\mathrm{PCBs}=160 \mathrm{pg} / \mathrm{L}, \mathrm{J}$-qualified). These concentrations were estimated (J-qualified) because they were less than the RL but greater than the DL. These concentrations were similar to the highest environmental sample concentrations, which were also low and estimated (total dioxins/furans $=0.851$ pg TEQ/L, J-qualified; total PCBs=184 pg/L, J-qualified; see section, "Water Chemistry Data"). These low estimated concentrations in the environmental samples and field blank sample were more than 10 times higher than the concentrations measured in the associated laboratory blank samples (based on comparison of individual congeners) and met all laboratory quality-assurance and quality-control criteria for quantified data (that is, retention times, ion ratios). Therefore, the results were not rejected during data review. Instead, this indicates a need for additional field blank sampling, including paired trip blanks and equipment blanks using blank water that has met quality assurance and quality control standards by the analyzing laboratory. The low concentrations in environmental water samples are reported with an appropriate footnote (see section "Water Chemistry Data"). 
Table 5. Quality assurance results for whole water samples, Duwamish River at Golf Course at Tukwila, Washington, 2013.

[Sample date and type: $\mathbf{Q}$, qualifer (Blank cells indicate an unqualified detection); U, not detected above reporting limit; UJ, not detected above detection limit; J, estimated. Abbreviations: HRMS, high-resolution mass spectrometry; LRMS, low-resolution mass spectrometry; mg/L, milligram per liter; pg/L, picogram per liter; pg TEQ/L, picograms toxic equivalent per liter; $\mu \mathrm{g} / \mathrm{L}$, microgram per liter; na, not applicable; -, no analysis done. See appendix for complete analyte results]

\begin{tabular}{|c|c|c|c|c|c|c|c|c|c|}
\hline \multirow{3}{*}{ Parameter name } & \multirow{3}{*}{$\begin{array}{c}\text { Chemical } \\
\text { Abstracts } \\
\text { Service } \\
\text { No. }\end{array}$} & \multirow{3}{*}{ Unit } & \multicolumn{7}{|c|}{ Sample date and type } \\
\hline & & & \multicolumn{2}{|c|}{$\begin{array}{l}\text { Field blank } \\
\text { (05-13-2013) }\end{array}$} & \multicolumn{2}{|c|}{$\begin{array}{c}\text { Environmental } \\
\text { sample } \\
(04-29-2013)\end{array}$} & \multicolumn{2}{|c|}{$\begin{array}{l}\text { Field replicate (04- } \\
\qquad 29-2013)\end{array}$} & \multirow{2}{*}{$\begin{array}{c}\text { Relative percen } \\
\text { difference } \\
\text { between } \\
04-29-2013 \\
\text { replicates }\end{array}$} \\
\hline & & & Result & $\mathbf{0}$ & Result & $\mathbf{0}$ & Result & $\mathbf{0}$ & \\
\hline Total organic carbon & na & $\mathrm{mg} / \mathrm{L}$ & 1.5 & $\mathrm{U}$ & 2.59 & & 1.73 & & 40 \\
\hline \multicolumn{10}{|c|}{ Metals } \\
\hline Arsenic & $7440-38-2$ & $\mathrm{mg} / \mathrm{L}$ & 0.2 & $\mathrm{U}$ & 0.6 & & 0.6 & & 0 \\
\hline Barium & $7440-39-3$ & $\mathrm{mg} / \mathrm{L}$ & 0.5 & $\mathrm{U}$ & 3.8 & & 3.8 & & 0 \\
\hline Copper & $7440-50-8$ & $\mathrm{mg} / \mathrm{L}$ & 0.5 & $\mathrm{U}$ & 0.5 & $\mathrm{U}$ & 1 & & - \\
\hline Lead & 7439-92-1 & $\mathrm{mg} / \mathrm{L}$ & 0.1 & $\mathrm{U}$ & 0.2 & & 0.2 & & 0 \\
\hline Nickel & $7440-02-0$ & $\mathrm{mg} / \mathrm{L}$ & 0.5 & $\mathrm{U}$ & 0.5 & $\mathrm{U}$ & 0.6 & & - \\
\hline Vanadium & $7440-62-2$ & $\mathrm{mg} / \mathrm{L}$ & 0.2 & $\mathrm{U}$ & 1.3 & & 1.4 & & -7 \\
\hline \multicolumn{10}{|c|}{ Dioxins and furans } \\
\hline Total hexa-dioxins & $34465-46-8$ & $\mathrm{pg} / \mathrm{L}$ & 2.00 & $\mathrm{~J}$ & 0.512 & UJ & 0.496 & UJ & - \\
\hline Total hepta-dioxins & $37871-00-4$ & $\mathrm{pg} / \mathrm{L}$ & 1.51 & $\mathrm{~J}$ & 1.30 & $\mathrm{~J}$ & 0.951 & $\mathrm{~J}$ & 31 \\
\hline Total octa-dioxins & $3268-87-9$ & $\mathrm{pg} / \mathrm{L}$ & 4.08 & UJ & 11.9 & $\mathrm{~J}$ & 9.19 & $\mathrm{~J}$ & 26 \\
\hline Total hexa-furans & 55684-94-1 & $\mathrm{pg} / \mathrm{L}$ & 0.655 & $\mathrm{~J}$ & 0.512 & UJ & 0.496 & UJ & - \\
\hline Total hepta-furans & 38998-75-3 & $\mathrm{pg} / \mathrm{L}$ & 0.993 & $\mathrm{~J}$ & 0.518 & $\mathrm{~J}$ & 0.496 & UJ & - \\
\hline Total octa-furans & 39001-02-0 & $\mathrm{pg} / \mathrm{L}$ & 2.24 & $\mathrm{~J}$ & 0.685 & UJ & 0.597 & UJ & - \\
\hline Total dioxins/furans & na & $\mathrm{pg} / \mathrm{L}$ & 7.40 & $\mathrm{~J}$ & 13.7 & $\mathrm{~J}$ & 10.1 & $\mathrm{~J}$ & 30 \\
\hline Total dioxins/furans & na & pg TEQ/L & 1.05 & $\mathrm{~J}$ & 0.826 & $\mathrm{~J}$ & 0.794 & $\mathrm{~J}$ & 4 \\
\hline \multicolumn{10}{|c|}{ Polychlorinated biphenyl homologue (by high-resolution mass spectrometry [HRMS]) } \\
\hline Total monochloro biphenyls & 27323-18-8 & $\mathrm{pg} / \mathrm{L}$ & 6.36 & & 7.81 & $\mathrm{~J}$ & 7.49 & $\mathrm{~J}$ & 4 \\
\hline Total dichloro biphenyls & 25512-42-9 & $\mathrm{pg} / \mathrm{L}$ & 6.07 & & 16.1 & & 13.9 & $\mathrm{~J}$ & 15 \\
\hline Total trichloro biphenyls & 25323-68-6 & $\mathrm{pg} / \mathrm{L}$ & 48.8 & $\mathrm{~J}$ & 17.0 & $\mathrm{~J}$ & 10.7 & $\mathrm{~J}$ & 46 \\
\hline Total tetrachloro biphenyls & 26914-33-0 & $\mathrm{pg} / \mathrm{L}$ & 66.1 & $\mathrm{~J}$ & 10.6 & $\mathrm{~J}$ & 14.0 & $\mathrm{~J}$ & -27 \\
\hline Total pentachloro biphenyls & 25429-29-2 & $\mathrm{pg} / \mathrm{L}$ & 25.1 & $\mathrm{~J}$ & 17.8 & $\mathrm{~J}$ & 28.2 & $\mathrm{~J}$ & -45 \\
\hline Total hexachloro biphenyls & 26601-64-9 & $\mathrm{pg} / \mathrm{L}$ & 7.87 & $\mathrm{~J}$ & 9.99 & $\mathrm{~J}$ & 13.8 & $\mathrm{~J}$ & -32 \\
\hline Total heptachloro biphenyls & 28655-71-2 & $\mathrm{pg} / \mathrm{L}$ & 1.90 & UJ & 0.851 & $\mathrm{~J}$ & 1.22 & $\mathrm{~J}$ & -36 \\
\hline Total octachloro biphenyls & $55722-26-4$ & $\mathrm{pg} / \mathrm{L}$ & 2.29 & UJ & 1.75 & UJ & 1.44 & UJ & - \\
\hline Total nonachloro biphenyls & $53742-07-7$ & $\mathrm{pg} / \mathrm{L}$ & 2.59 & UJ & 2.30 & UJ & 1.95 & UJ & - \\
\hline Total decachloro biphenyls & 2051-24-3 & $\mathrm{pg} / \mathrm{L}$ & 1.85 & UJ & 1.55 & UJ & 1.13 & UJ & - \\
\hline $\begin{array}{l}\text { Total polychlorinated biphenyl } \\
\text { Aroclors (by HRMS) }\end{array}$ & $1336-36-3$ & $\mathrm{pg} / \mathrm{L}$ & 160 & $\mathrm{~J}$ & 80.1 & $\mathrm{~J}$ & 89.2 & $\mathrm{~J}$ & -11 \\
\hline \multicolumn{10}{|c|}{ Polychlorinated biphenyl Aroclors (by by high-resolution mass spectrometry [HRMS]) } \\
\hline Aroclor 1242 & $53469-21-9$ & pg/L & 82.9 & & 16.6 & & 15.7 & & 5 \\
\hline Aroclor 1254 & 11097-69-1 & $\mathrm{pg} / \mathrm{L}$ & 55.2 & & 6.70 & UJ & 16.0 & UJ & - \\
\hline Aroclor 1260 & 11096-82-5 & $\mathrm{pg} / \mathrm{L}$ & 1.90 & UJ & 1.45 & UJ & 2.74 & UJ & - \\
\hline \multicolumn{10}{|c|}{ Polychlorinated biphenyl Aroclors (by low-resolution mass spectrometry [LRMS]) } \\
\hline Aroclor 1242 & 53469-21-9 & $\mu \mathrm{g} / \mathrm{L}$ & 0.01 & $\mathrm{U}$ & 0.01 & $\mathrm{U}$ & 0.01 & $\mathrm{U}$ & - \\
\hline Aroclor 1254 & 11097-69-1 & $\mu \mathrm{g} / \mathrm{L}$ & 0.01 & $\mathrm{U}$ & 0.01 & $\mathrm{U}$ & 0.01 & $\mathrm{U}$ & - \\
\hline Aroclor 1260 & 11096-82-5 & $\mu \mathrm{g} / \mathrm{L}$ & 0.01 & $\mathrm{U}$ & 0.01 & $\mathrm{U}$ & 0.01 & $\mathrm{U}$ & - \\
\hline
\end{tabular}


The absolute relative percent difference between analyte concentrations in sequential field replicates of water samples collected on April 29, 2013 ranged from 0 to 46 percent (table 5).

The source blank used to conduct the suspended-sediment equipment blank (see section, “Quality Assurance and Quality Control" in the section "Methods" section) contained metals, TOC, hexavalent chromium, and low levels of dioxins/furans and PCBs (table 6). The percent increase in concentration from the source blank to the equipment blank (that is, the source blank after it had been processed through the field and laboratory equipment) was 16 percent or less for the metals. The percent TOC in the equipment blank was 0.279 percent as compared to 0.037 percent in the source blank. Hexavalent chromium was $1.18 \mathrm{mg} / \mathrm{kg}$ in the equipment blank as compared to $0.675 \mathrm{mg} / \mathrm{kg}$ in the source blank. Dioxins/furans and PCBs were undetected in the source blank and detected at very low concentration in the equipment blank (dioxins/ furans $=0.0281 \mathrm{ng} \mathrm{TEQ} / \mathrm{kg}$, J-qualified; total $\mathrm{PCBs}=17.0 \mathrm{ng} / \mathrm{kg}$, J-qualified).

Bis(2-ethylhexyl)phthalate and PAHs were detected in the equipment blank, but not in the source blank, and appear to have been introduced during sample processing. Bis(2ethylhexyl)phthalate was present at $36 \mu \mathrm{g} / \mathrm{kg}$ in the equipment blank as compared to less than $24 \mu \mathrm{g} / \mathrm{kg}$ in the source blank. PAHs were detected in the equipment blank from $0.73 \mu \mathrm{g} / \mathrm{kg}$ (benzo(g,h,i)perylene) to $3.07 \mu \mathrm{g} / \mathrm{kg}$ (pyrene). Total cPAHs in the equipment blank $(0.13 \mu \mathrm{g}$ TEQ $/ \mathrm{kg})$ were nearly 400 times smaller than the average cPAH concentrations in the environmental suspended-sediment samples (51.3 $\mu \mathrm{g}$ TEQ/ kg). Overall, suspended-sediment equipment blank detections were at least 10 times to greater than 1,000 times less than average environmental concentrations (table 6). Therefore, the suspended-sediment sample collection and laboratory processing protocol was deemed appropriate for this project, and no suspended-sediment environmental data was qualified.

The relative percent difference between the parameter concentration in bed-sediment field split samples (table 7) was less than 35 percent, with the following exceptions: naphthalene (80 percent), 2-methylnaphthalene (62.5 percent), and 1-methylnaphthalene (50 percent). Although some homologue totals of dioxins/furans varied between the split samples, the total dioxins/furans (ng TEQ/kg) difference was 6 percent. Total PCBs varied by 57 percent, and PCB Aroclor 1260 varied by 98 percent, owing to large differences between samples in the hexa- through nona-homologues.

Acceptance criteria selected for the PSRM material followed that of the U.S. Army Corps of Engineers (http:// www.nws.usace.army.mil/Missions/CivilWorks/Dredging/ $\underline{\text { SRM.aspx }}$, and was \pm 50 percent for individual dioxins/furans and $\mathrm{PCB}$ congeners and within the 95 percent confidence interval for PCB Aroclor 1260. The laboratory results for the PSRM for this project were within the acceptance criteria for all compounds, with the exception of 1,2,3,7,8,9-HXCDF and 2,3,4,6,7,8-HXCDF (table 8).

Other than the low-level dioxins/furans and PCB congener detections in the water field blank sample, which resulted in the qualified environmental water data below, the results from the field quality-assurance samples were deemed satisfactory and no additional qualifiers were applied to the environmental data. 

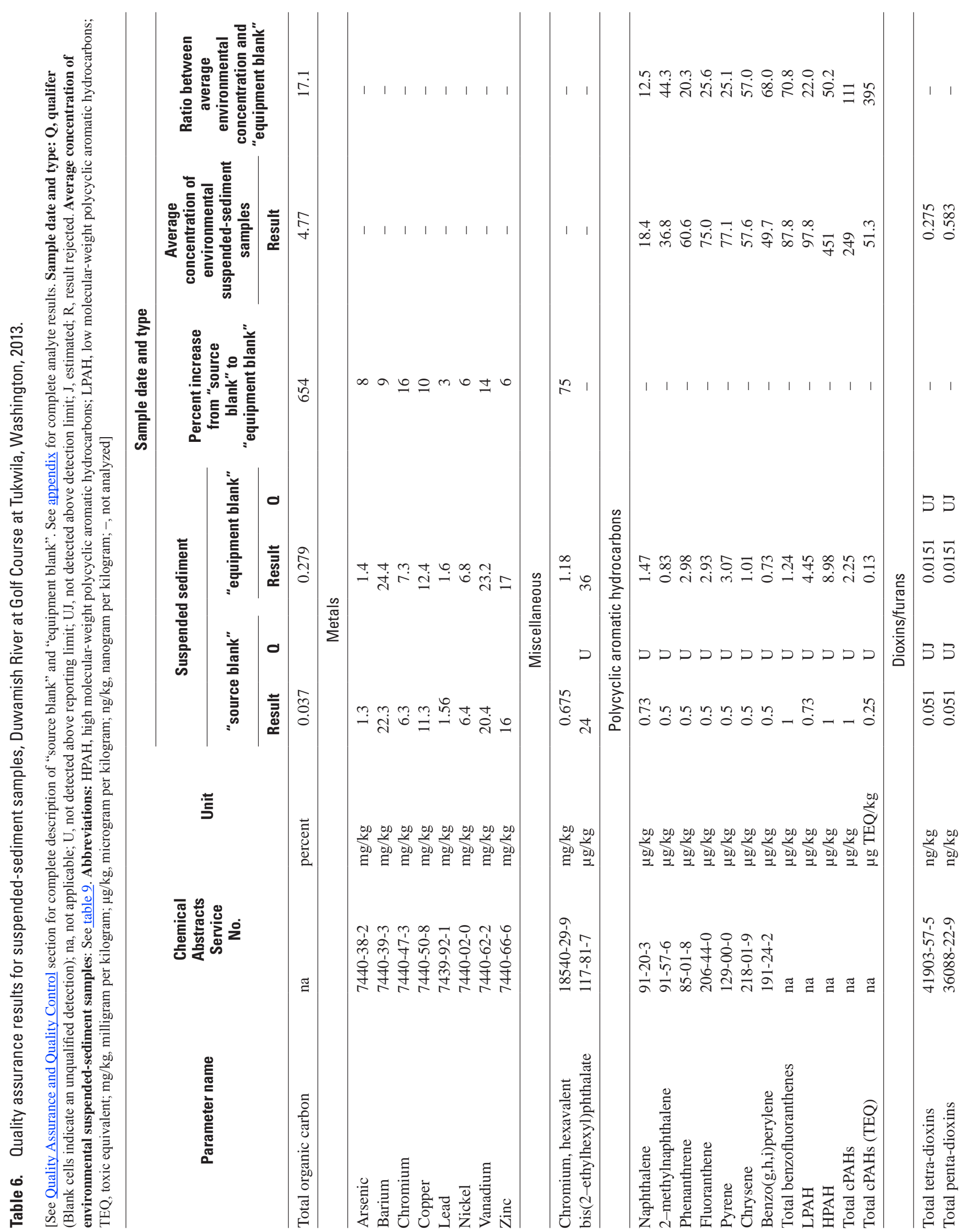


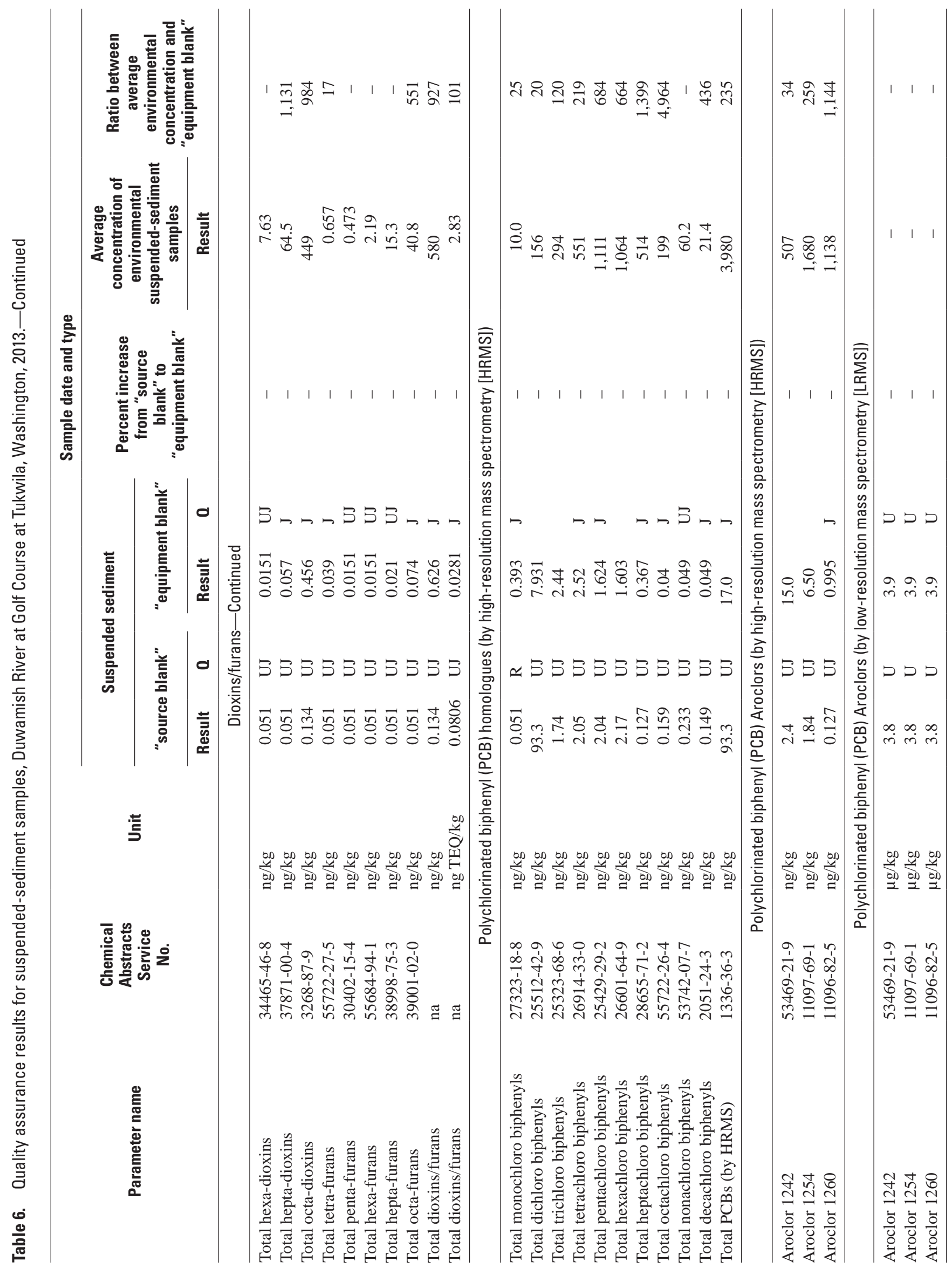


Table 7. Quality assurance results for bed-sediment samples, Duwamish River at Golf Course at Tukwila, Washington, 2013.

[Sample date and type: $\mathbf{Q}$, qualifer (Blank cells indicate an unqualified detection); $\mathrm{U}$, not detected above reporting limit; UJ, not detected above detection limit; J, estimated. Abbreviations: cPAH, carcinogenic polycyclic aromatic hydrocarbon; HPAH, high molecular-weight polycyclic aromatic hydrocarbons; LPAH, low molecular-weight polycyclic aromatic hydrocarbons; mg/kg, milligram per kilogram; na, not applicable; ng/kg, nanogram per kilogram; TEQ, toxic equivalent; $\mu \mathrm{g} / \mathrm{kg}$, microgram per kilogram; -, no analysis done. See appendix for complete analyte results]

\begin{tabular}{|c|c|c|c|c|c|c|c|}
\hline \multirow{3}{*}{ Parameter name } & \multirow{3}{*}{$\begin{array}{c}\text { Chemical } \\
\text { Abstracts } \\
\text { Service } \\
\text { No. }\end{array}$} & \multirow{3}{*}{ Unit } & \multicolumn{5}{|c|}{ Sample date and type } \\
\hline & & & \multicolumn{2}{|c|}{$\begin{array}{c}\text { Field split } \\
(04-26-2013)\end{array}$} & \multicolumn{2}{|c|}{$\begin{array}{c}\text { Environmental } \\
\text { sample } \\
(04-26-2013)\end{array}$} & \multirow[t]{2}{*}{$\begin{array}{l}\text { Relative percent } \\
\text { difference between } \\
\text { 04-26-2013 splits }\end{array}$} \\
\hline & & & Result & $\mathbf{0}$ & Result & $\mathbf{0}$ & \\
\hline Total organic carbon & na & percent & 1.49 & & 1.41 & & -6 \\
\hline Particle/grain size, Phi scale <-1 & na & percent & 0.1 & $\mathrm{U}$ & 0.1 & $\mathrm{U}$ & - \\
\hline Particle/grain size, Phi scale -1 to 0 & na & percent & 0.1 & & 0.1 & & 0 \\
\hline Particle/grain size, Phi scale 0 to 1 & na & percent & 0.8 & & 0.7 & & -13 \\
\hline Particle/grain size, Phi scale 1 to 2 & na & percent & 9.4 & & 9.3 & & -1 \\
\hline Particle/grain size, Phi scale 2 to 3 & na & percent & 43.6 & & 42.4 & & -3 \\
\hline Particle/grain size, Phi scale 7 to 8 & na & percent & 1.6 & & 1.7 & & 6 \\
\hline Particle/grain size, Phi scale 8 to 9 & na & percent & 0.9 & & 1.1 & & 20 \\
\hline Particle/grain size, Phi scale 9 to 10 & na & percent & 0.6 & & 0.7 & & 15 \\
\hline Particle/grain size, Phi scale >10 & na & percent & 0.8 & & 0.8 & & 0 \\
\hline Particle/grain size, fines (silt/clay) & na & percent & 17.5 & & 18.5 & & 6 \\
\hline \multicolumn{8}{|c|}{ Metals } \\
\hline Arsenic & $7440-38-2$ & $\mathrm{mg} / \mathrm{kg}$ & 4.7 & & 5 & & 6 \\
\hline Barium & $7440-39-3$ & $\mathrm{mg} / \mathrm{kg}$ & 78.1 & & 76.5 & & -2 \\
\hline Chromium & $7440-47-3$ & $\mathrm{mg} / \mathrm{kg}$ & 15.7 & & 15.9 & & 1 \\
\hline Copper & $7440-50-8$ & $\mathrm{mg} / \mathrm{kg}$ & 18.6 & & 18.6 & & 0 \\
\hline \multicolumn{8}{|c|}{ Miscellaneous } \\
\hline Benzyl alcohol & $100-51-6$ & $\mu \mathrm{g} / \mathrm{kg}$ & 200 & & 190 & & -5 \\
\hline bis(2-Ethylhexyl)phthalate & $117-81-7$ & $\mu \mathrm{g} / \mathrm{kg}$ & 37 & & 38 & & 3 \\
\hline \multicolumn{8}{|c|}{ Polycyclic aromatic hydrocarbons } \\
\hline Naphthalene & $91-20-3$ & $\mu \mathrm{g} / \mathrm{kg}$ & 5.63 & & 13.1 & & 80 \\
\hline 2-Methylnaphthalene & $91-57-6$ & $\mu \mathrm{g} / \mathrm{kg}$ & 12.5 & & 24 & & 63 \\
\hline 1-Methylnaphthalene & $90-12-0$ & $\mu \mathrm{g} / \mathrm{kg}$ & 12.2 & & 20.3 & & 50 \\
\hline Acenaphthylene & 208-96-8 & $\mu \mathrm{g} / \mathrm{kg}$ & 0.66 & & 0.7 & & 6 \\
\hline Acenaphthene & $83-32-9$ & $\mu \mathrm{g} / \mathrm{kg}$ & 0.81 & & 0.78 & & -4 \\
\hline Fluorene & $86-73-7$ & $\mu \mathrm{g} / \mathrm{kg}$ & 0.96 & & 1.03 & & 7 \\
\hline Phenanthrene & 85-01-8 & $\mu \mathrm{g} / \mathrm{kg}$ & 25.9 & & 27.6 & & 6 \\
\hline Anthracene & $120-12-7$ & $\mu \mathrm{g} / \mathrm{kg}$ & 2.38 & & 2.49 & & 5 \\
\hline Fluoranthene & 206-44-0 & $\mu \mathrm{g} / \mathrm{kg}$ & 14.6 & & 13.4 & & -9 \\
\hline Pyrene & $129-00-0$ & $\mu \mathrm{g} / \mathrm{kg}$ & 14.4 & & 14.5 & & 1 \\
\hline Benzo(a)anthracene & $56-55-3$ & $\mu \mathrm{g} / \mathrm{kg}$ & 7.13 & & 6.6 & & -8 \\
\hline Chrysene & 218-01-9 & $\mu \mathrm{g} / \mathrm{kg}$ & 12 & & 11.1 & & -8 \\
\hline Benzo(a)pyrene & $50-32-8$ & $\mu \mathrm{g} / \mathrm{kg}$ & 5.93 & & 5.45 & & -8 \\
\hline
\end{tabular}


Table 7. Quality assurance results for bed-sediment samples, Duwamish River at Golf Course at Tukwila, Washington, 2013.Continued

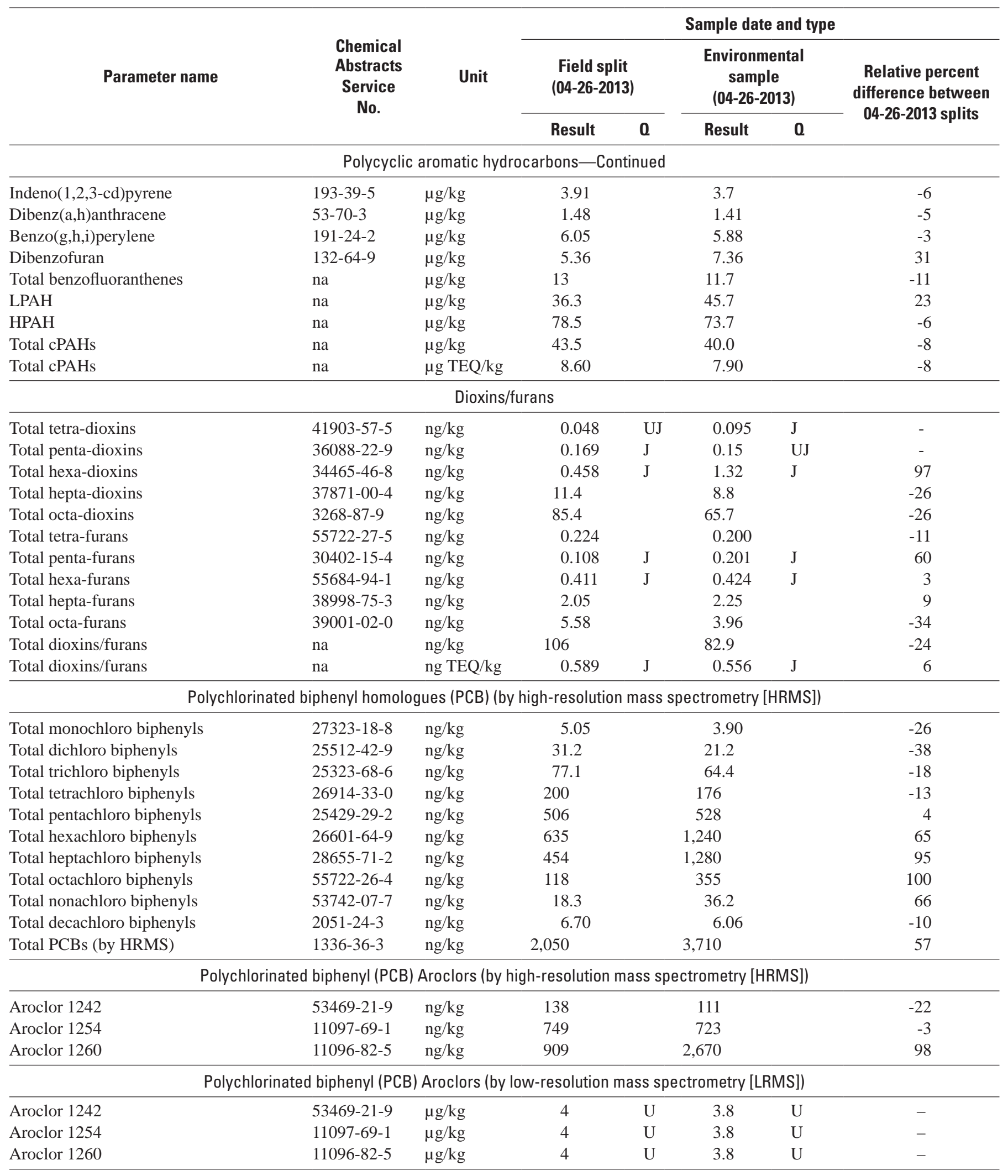


Table 8. Quality assurance results for the Puget Sound Reference Material (PSRM), Duwamish River at Golf Course at Tukwila, Washington, 2013.

[Sample date and type: Q, qualifer (Blank cells indicate an unqualified detection); UJ, not detected above detection limit; J, estimated. PSRM action Low and High is -50 percent and +50 percent, respectively (or 95 percent confidence interval for Aroclor 1260) of average interlaboratory round-robin results. Abbreviations: HRMS, high-resolution mass spectrometry; LRMS, low-resolution mass spectrometry; pg/g, picogram per gram; PSRM, Puget Sound Reference Material; $\mu \mathrm{g} / \mathrm{kg}$, microgram per kilogram; -, not determined. See http://www.nws.usace.army.mil/Missions/CivilWorks/Dredging/SRM.aspx for additional information]

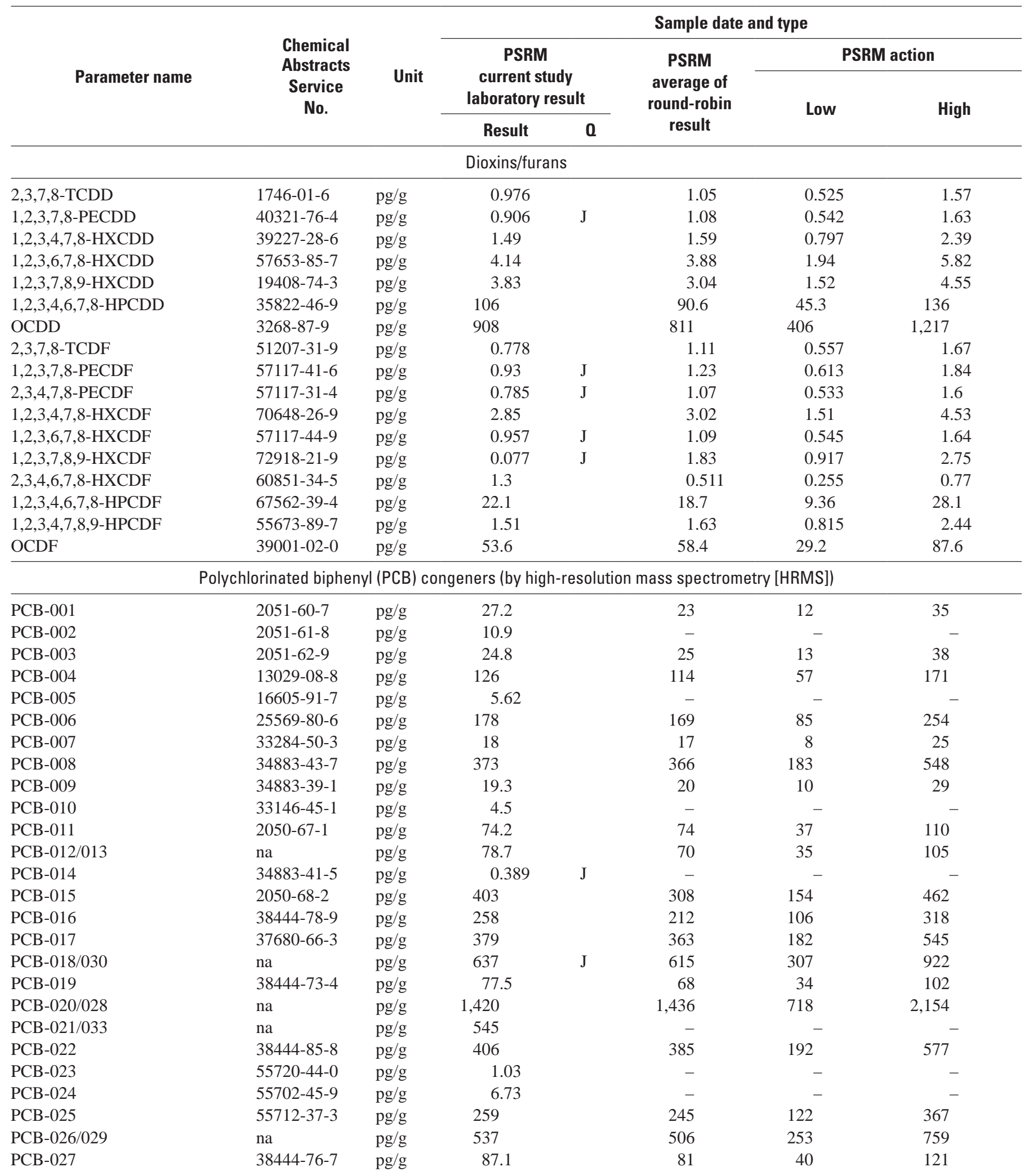


Table 8. Quality assurance results for the Puget Sound Reference Material (PSRM), Duwamish River at Golf Course at Tukwila, Washington, 2013.-Continued

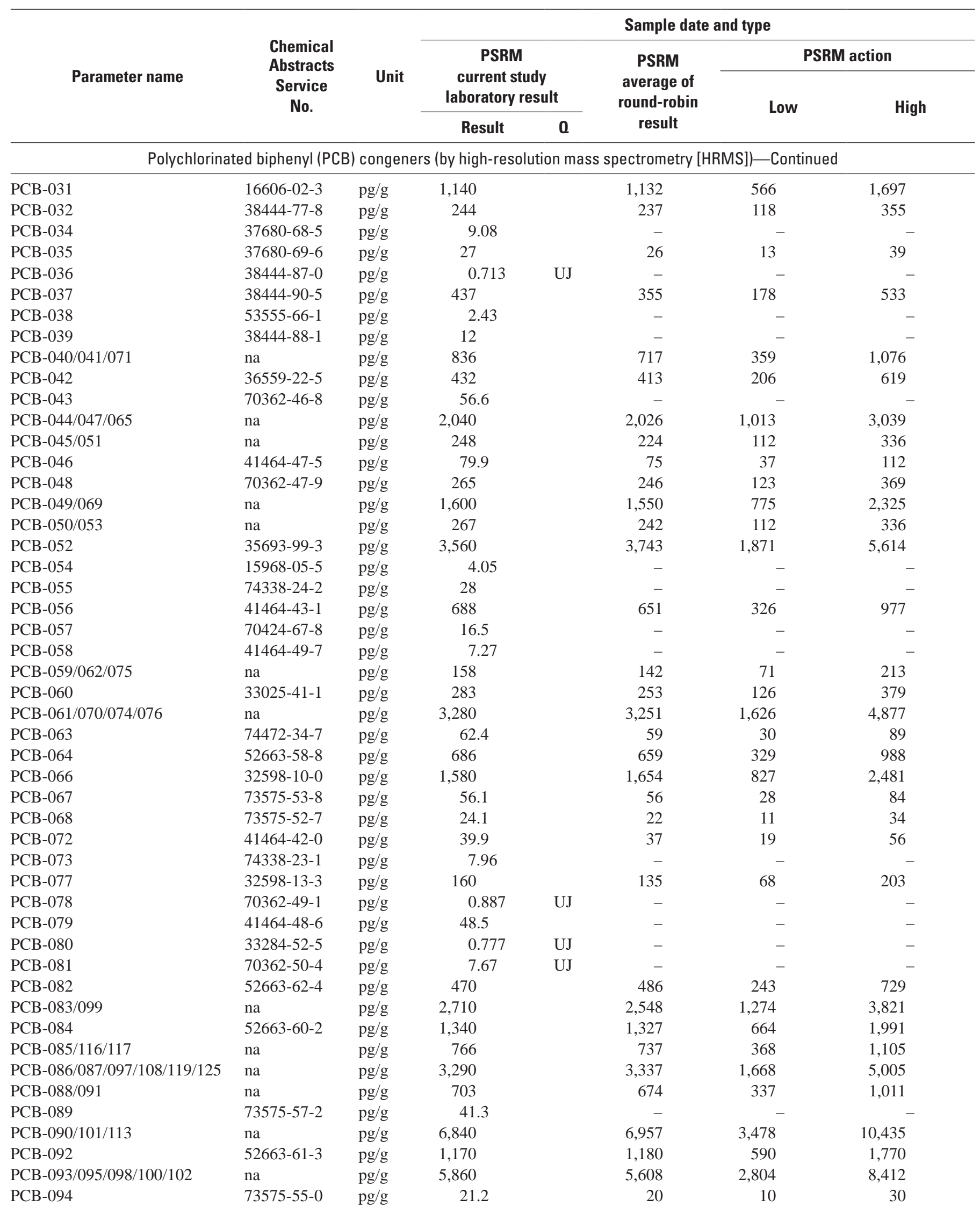


Table 8. Quality assurance results for the Puget Sound Reference Material (PSRM), Duwamish River at Golf Course at Tukwila, Washington, 2013.-Continued

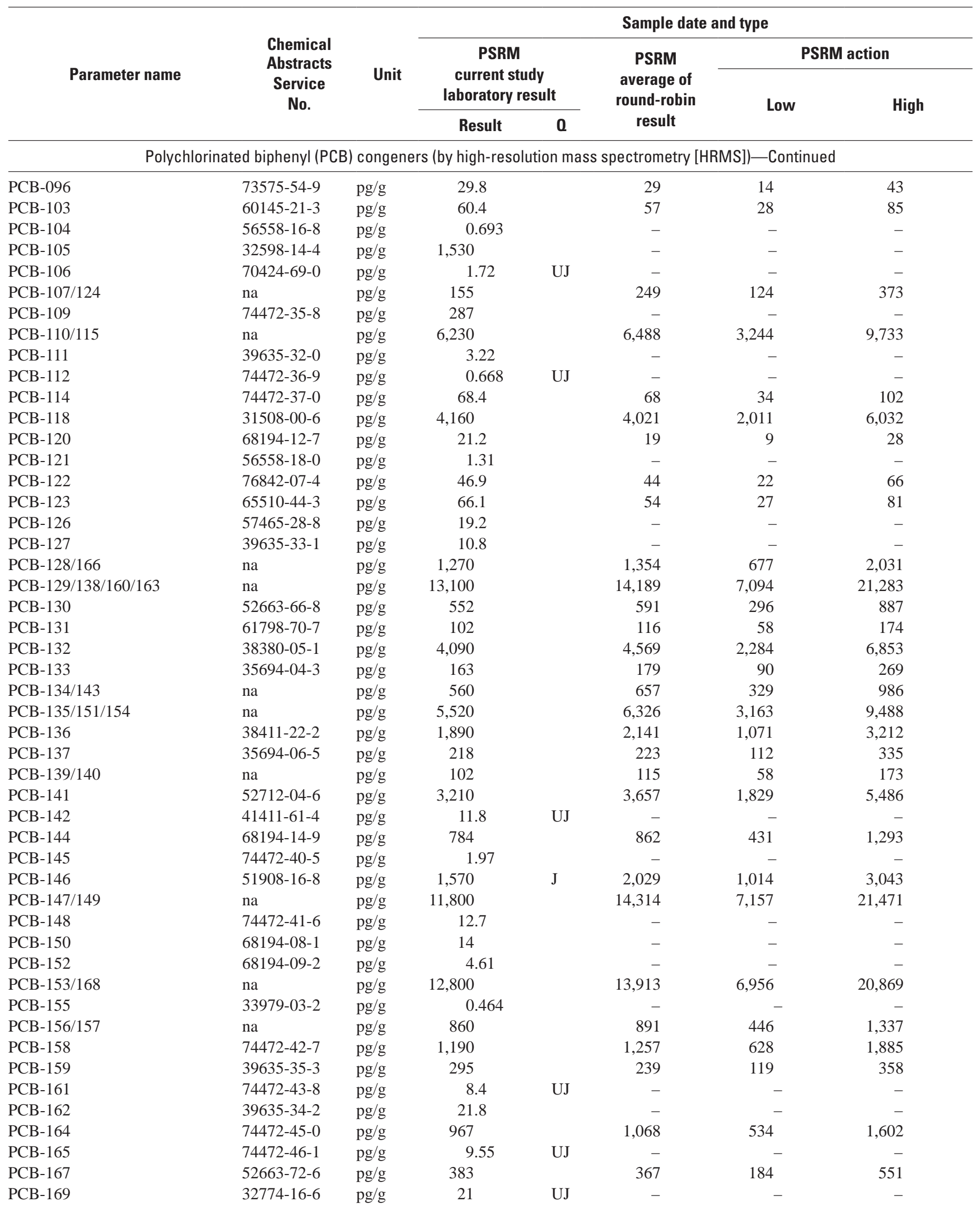


Table 8. Quality assurance results for the Puget Sound Reference Material (PSRM), Duwamish River at Golf Course at Tukwila, Washington, 2013.-Continued

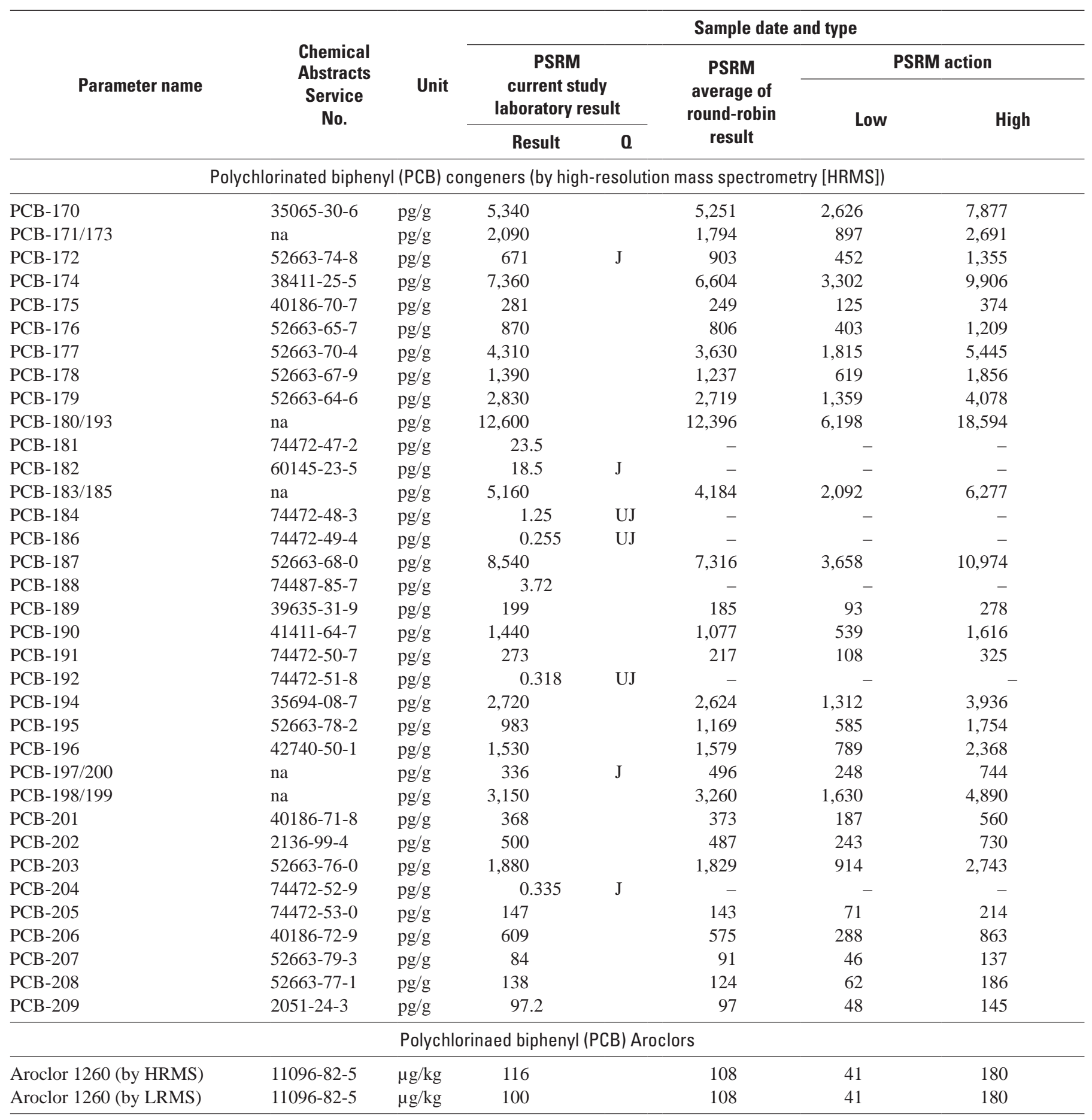




\section{Water-Chemistry Data}

Total organic carbon, metals, dioxins/furans, and PCB cogeners were detected in water samples (table 9). The following compound groups were analyzed for, but were not detected: PAHs, other semivolatile organic compounds, pesticides, VOCs, hexavalent chromium, and butyltins. In four of the seven water samples collected, TOC was greater than the $\mathrm{RL}$ of $1.5 \mathrm{mg} / \mathrm{L}$ at concentrations ranging from $1.86 \mathrm{mg} / \mathrm{L}$ during a low-precipitation period to $2.78 \mathrm{mg} / \mathrm{L}$ during the storm peak. Of the dioxin/furan congeners, only the hepta- and octa-congeners were detected. All environmental detections of total dioxins/furans and total PCBs (table 9) were estimated because they were less than the RL (J-qualified). These levels were similar to concentrations in the one field blank sample (table 5, see section, “Quality-Assurance Data” for additional details).

Eight metals were detected in water samples: arsenic, barium, chromium, copper, lead, nickel, vanadium, and zinc (fig. 4, table 9). Mercury was not detected greater than the detection level of $20 \mathrm{ng} / \mathrm{L}$. Nickel was detected only during the rising limb and storm peak and chromium and zinc were detected only during the storm peak. Concentrations of the remaining five detected metals during the storm peak were 2-3.5 times greater than the average concentration of the five low-precipitation periods.

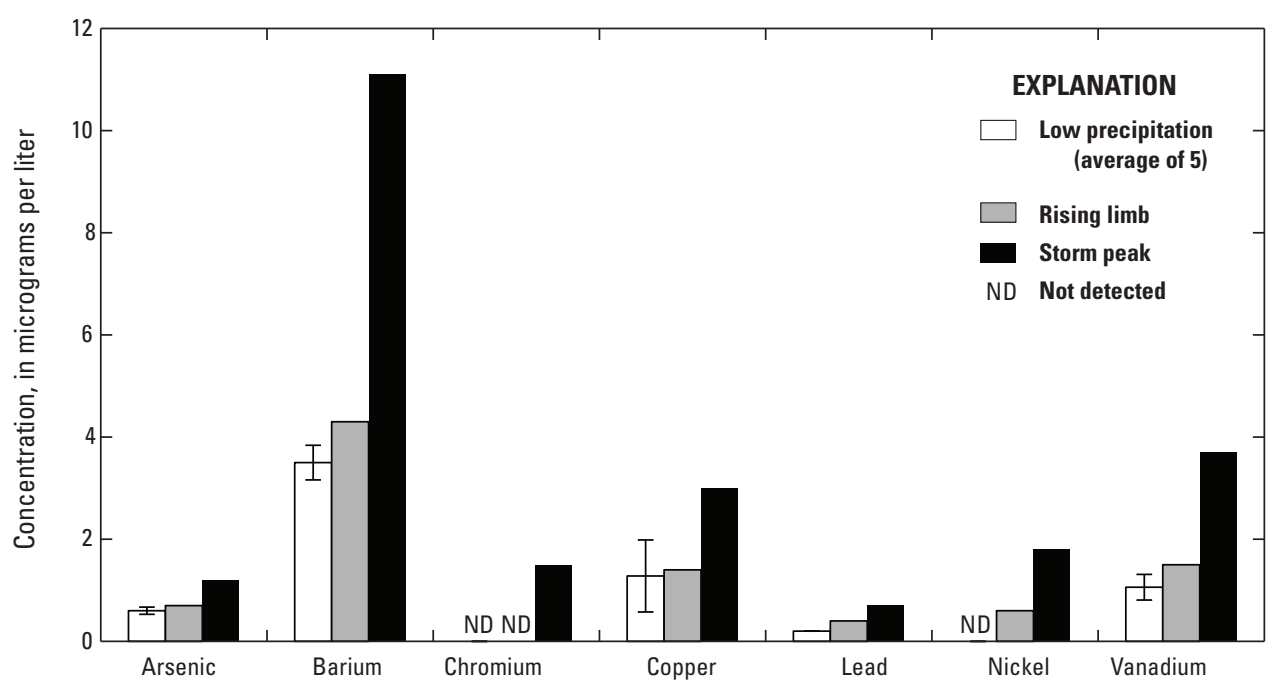

Figure 4. Concentrations of metals in whole-water samples, Duwamish River at Golf Course at Tukwila, Washington, 2013. The low-precipitation concentration represents the average of five samples with 72 -hour antecedent rainfall less than or equal to $0.40 \mathrm{inch}$. Error bars represent \pm 1 standard deviation. 


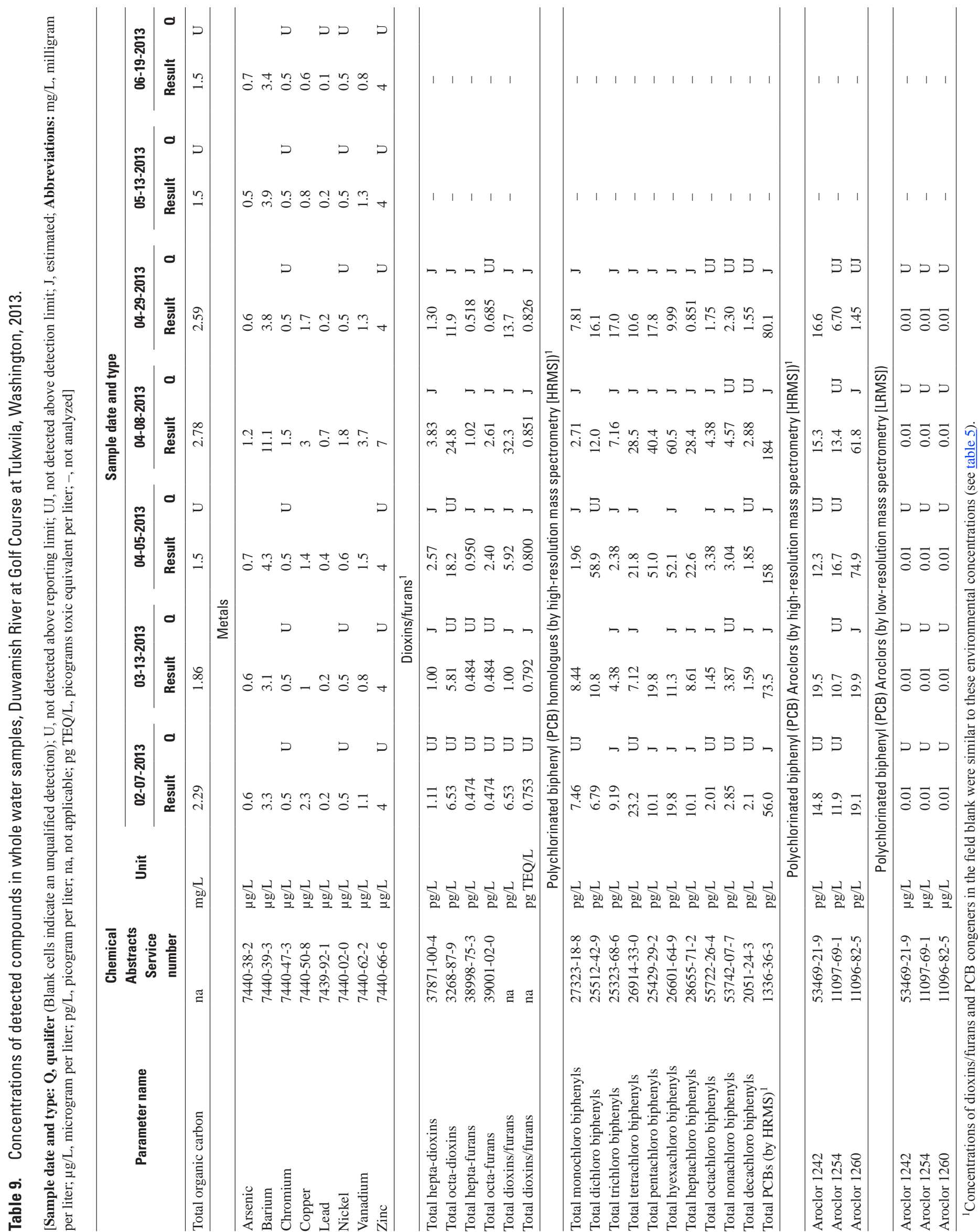




\section{Suspended-Sediment Chemistry Data}

In suspended-sediment samples, TOC, metals, PAHs, dioxins/furans, and PCBs were detected during low precipitation periods and storm samples (table 10). Because of limited sample mass and analyte prioritization, no analysis was done for the following compound groups: other semivolatile organic compounds, VOCs, pesticides, butyltins, and hexavalent chromium. Total organic carbon ranged from 3.60 to 6.38 percent. Total cPAHs during the rising limb and storm peak were approximately $50 \mu \mathrm{TEQ} / \mathrm{kg}$. Concentrations of total dioxins/furans increased with increasing precipitation, from $1.27 \mathrm{ng} \mathrm{TEQ} / \mathrm{kg}$ (0.21 in. rainfall) to $4.20 \mathrm{ng} \mathrm{TEQ} / \mathrm{kg}$
(1.3 in. rainfall). Similarly, total PCBs increased from $2,430 \mathrm{ng} / \mathrm{kg}$ (0.21 in. rainfall) up to 5,360 ng/kg (1.3 in. rainfall). Nine metals were detected-the same eight that were detected in water samples, plus mercury (table 10). During a low precipitation period (May 13, 2013), very elevated concentrations of chromium $(2,180 \mathrm{mg} / \mathrm{kg})$ and nickel $(1,130 \mathrm{mg} / \mathrm{kg})$ were measured and confirmed during laboratory re-analyses (table 10). Both compounds were not detected in the corresponding water sample (table 9). On that day, there was a short period of intense precipitation that included rain and hail and caused local storm drain runoff and a doubling of turbidity (table 4) that occurred after the water sample had been collected, but during the suspended-sediment sample collection.

Table 10. Compounds detected in suspended-sediment samples, Duwamish River at Golf Course at Tukwila, Washington, 2013.

[Sample date and type: Q, qualifer (Blank cells indicate an unqualified detection); na, not applicable; U, not detected above reporting limit; J, estimated; Abbreviations: cPAH, carcinogenic polycyclic aromatic hydrocarbon; HPAH, high molecular-weight polycyclic aromatic hydrocarbon; LPAH, low molecularweight polycyclic aromatic hydrocarbon; mg/L, milligram per liter; $\mu$ g/L, microgram per liter; ng/L, nanogram per liter; PCB, polychlorinated biphenyl; TEQ, toxic equivalent; -, no analysis done]

\begin{tabular}{|c|c|c|c|c|c|c|c|c|c|c|c|c|}
\hline \multirow{3}{*}{ Parameter name } & \multirow{3}{*}{$\begin{array}{c}\text { Chemical } \\
\text { Abstracts } \\
\text { Service } \\
\text { No. }\end{array}$} & \multirow{3}{*}{ Unit } & \multicolumn{10}{|c|}{ Sample date and type } \\
\hline & & & \multicolumn{2}{|c|}{$02-07-2013$} & \multicolumn{2}{|c|}{ 03-13-2013 } & \multicolumn{2}{|c|}{$04-05-2013$} & \multicolumn{2}{|c|}{ 04-08-2013 } & \multicolumn{2}{|c|}{$05-13-2013$} \\
\hline & & & Result & $\mathbf{0}$ & Result & $\mathbf{0}$ & Result & $\mathbf{0}$ & Result & $\mathbf{0}$ & Result & $\mathbf{0}$ \\
\hline Total organic carbon & na & percent & - & & - & & 3.60 & & 4.32 & & 6.38 & \\
\hline \multicolumn{13}{|c|}{ Metals } \\
\hline Arsenic & $7440-38-2$ & $\mathrm{mg} / \mathrm{kg}$ & - & & - & & 10.7 & & 15.7 & & 12.0 & \\
\hline Barium & $7440-39-3$ & $\mathrm{mg} / \mathrm{kg}$ & - & & - & & 117 & & 214 & & 129 & \\
\hline Chromium & $7440-47-3$ & $\mathrm{mg} / \mathrm{kg}$ & - & & - & & 75.0 & & 170 & & 2,180 & \\
\hline Copper & $7440-50-8$ & $\mathrm{mg} / \mathrm{kg}$ & - & & - & & 32.0 & & 57.0 & & 86.0 & \\
\hline Lead & 7439-92-1 & $\mathrm{mg} / \mathrm{kg}$ & - & & - & & 11.1 & & 17.7 & & 10.0 & \\
\hline Mercury & 7439-97-6 & $\mathrm{mg} / \mathrm{kg}$ & - & & - & & 0.1 & & 0.2 & & $0.1 \mathrm{U}$ & \\
\hline Nickel & $7440-02-0$ & $\mathrm{mg} / \mathrm{kg}$ & - & & - & & 50.0 & & 114 & & 1,130 & \\
\hline Vanadium & $7440-62-2$ & $\mathrm{mg} / \mathrm{kg}$ & - & & - & & 59.0 & & 107 & & 56.0 & \\
\hline Zinc & 7440-66-6 & $\mathrm{mg} / \mathrm{kg}$ & - & & - & & 110 & & 170 & & 100 & \\
\hline \multicolumn{13}{|c|}{ Polycyclic aromatic hydrocarbons } \\
\hline Naphthalene & $91-20-3$ & $\mu g / k g$ & - & & - & & 9.15 & & 27.6 & & - & \\
\hline 2-Methylnaphthalene & $91-57-6$ & $\mu \mathrm{g} / \mathrm{kg}$ & - & & - & & 19.1 & & 54.4 & & - & \\
\hline 1-Methylnaphthalene & $90-12-0$ & $\mu g / k g$ & - & & - & & 8.25 & & 29.3 & & - & \\
\hline Acenaphthylene & 208-96-8 & $\mu \mathrm{g} / \mathrm{kg}$ & - & & - & & 3.7 & $\mathrm{U}$ & 4.58 & & - & \\
\hline Acenaphthene & 83-32-9 & $\mu g / k g$ & - & & - & & 3.7 & $\mathrm{U}$ & 3.66 & & - & \\
\hline Fluorene & $86-73-7$ & $\mu g / k g$ & - & & - & & 3.7 & $\mathrm{U}$ & 9.31 & & - & \\
\hline Phenanthrene & $85-01-8$ & $\mu \mathrm{g} / \mathrm{kg}$ & - & & - & & 44.7 & & 76.5 & & - & \\
\hline Anthracene & $120-12-7$ & $\mu g / k g$ & - & & - & & 4.51 & & 15.5 & & - & \\
\hline Fluoranthene & 206-44-0 & $\mu \mathrm{g} / \mathrm{kg}$ & - & & - & & 71.6 & & 78.4 & & - & \\
\hline Pyrene & 129-00-0 & $\mu g / k g$ & - & & - & & 73.3 & & 80.9 & & - & \\
\hline Benzo(a)anthracene & $56-55-3$ & $\mu \mathrm{g} / \mathrm{kg}$ & - & & - & & 25.5 & & 29.3 & & - & \\
\hline Chrysene & 218-01-9 & $\mu g / k g$ & - & & - & & 59.2 & & 55.9 & & - & \\
\hline Benzo(a)pyrene & $50-32-8$ & $\mu \mathrm{g} / \mathrm{kg}$ & - & & - & & 37.5 & & 32.6 & & - & \\
\hline Indeno(1,2,3-cd)pyrene & 193-39-5 & $\mu \mathrm{g} / \mathrm{kg}$ & - & & - & & 36.8 & & 28.8 & & - & \\
\hline Dibenz(a,h)anthracene & 53-70-3 & $\mu \mathrm{g} / \mathrm{kg}$ & - & & - & & 9.27 & & 8.05 & & - & \\
\hline Benzo(g,h,i)perylene & 191-24-2 & $\mu g / k g$ & - & & - & & 56.0 & & 43.3 & & - & \\
\hline Dibenzofuran & 132-64-9 & $\mu \mathrm{g} / \mathrm{kg}$ & - & & - & & 5.76 & & 13.8 & & - & \\
\hline Total benzofluoranthenes & TOTBFA & $\mu g / \mathrm{kg}$ & - & & - & & 97.0 & & 78.5 & & - & \\
\hline
\end{tabular}


Table 10. Compounds detected in suspended-sediment samples, Duwamish River at Golf Course at Tukwila, Washington, 2013. Continued

\begin{tabular}{|c|c|c|c|c|c|c|c|c|c|c|c|c|}
\hline \multirow{3}{*}{ Parameter name } & \multirow{3}{*}{$\begin{array}{c}\text { Chemical } \\
\text { Abstracts } \\
\text { Service } \\
\text { No. }\end{array}$} & \multirow{3}{*}{ Unit } & \multicolumn{10}{|c|}{ Sample date and type } \\
\hline & & & \multicolumn{2}{|c|}{ 02-07-2013 } & \multicolumn{2}{|c|}{ 03-13-2013 } & \multicolumn{2}{|c|}{ 04-05-2013 } & \multicolumn{2}{|c|}{ 04-08-2013 } & \multicolumn{2}{|c|}{ 05-13-2013 } \\
\hline & & & Result & $\mathbf{0}$ & Result & $\mathbf{0}$ & Result & $\mathbf{0}$ & Result & $\mathbf{0}$ & Result & $\mathbf{0}$ \\
\hline \multicolumn{13}{|c|}{ Polycyclic aromatic hydrocarbons-Continued } \\
\hline LPAH & na & $\mu \mathrm{g} / \mathrm{kg}$ & - & & - & & 58.4 & & 137 & & - & \\
\hline НРАН & na & $\mu \mathrm{g} / \mathrm{kg}$ & - & & - & & 466 & & 436 & & - & \\
\hline Total cPAHs & na & $\mu \mathrm{g} / \mathrm{kg}$ & - & & - & & 265 & & 233 & & - & \\
\hline Total cPAHs & na & $\mu g \mathrm{TEQ} / \mathrm{kg}$ & - & & - & & 54.9 & & 47.6 & & - & \\
\hline \multicolumn{13}{|c|}{ Dioxins/furans } \\
\hline Total tetra-dioxins & $41903-57-5$ & $\mathrm{ng} / \mathrm{kg}$ & 0.153 & $\mathrm{~J}$ & 0.346 & & 0.236 & & 0.365 & & - & \\
\hline Total penta-dioxins & $36088-22-9$ & $\mathrm{ng} / \mathrm{kg}$ & 0.289 & $\mathrm{~J}$ & 0.619 & $\mathrm{~J}$ & 0.577 & $\mathrm{~J}$ & 0.845 & $\mathrm{~J}$ & - & \\
\hline Total hexa-dioxins & $34465-46-8$ & $\mathrm{ng} / \mathrm{kg}$ & 2.90 & $\mathrm{~J}$ & 5.97 & & 9.36 & & 12.3 & & - & \\
\hline Total hepta-dioxins & $37871-00-4$ & $\mathrm{ng} / \mathrm{kg}$ & 27.4 & & 61.3 & & 76.9 & & 92.3 & & - & \\
\hline Total octa-dioxins & $3268-87-9$ & $\mathrm{ng} / \mathrm{kg}$ & 217 & & 470 & & 501 & & 606 & & - & \\
\hline Total tetra-furans & $55722-27-5$ & $\mathrm{ng} / \mathrm{kg}$ & 0.383 & & 0.795 & & 0.569 & & 0.881 & & - & \\
\hline Total penta-furans & $30402-15-4$ & $\mathrm{ng} / \mathrm{kg}$ & 0.304 & $\mathrm{~J}$ & 0.616 & $\mathrm{~J}$ & 0.535 & $\mathrm{~J}$ & 0.436 & $\mathrm{~J}$ & - & \\
\hline Total hexa-furans & 55684-94-1 & $\mathrm{ng} / \mathrm{kg}$ & 0.966 & $\mathrm{~J}$ & 2.04 & $\mathrm{~J}$ & 2.41 & $\mathrm{~J}$ & 3.36 & $\mathrm{~J}$ & - & \\
\hline Total hepta-furans & $38998-75-3$ & $\mathrm{ng} / \mathrm{kg}$ & 5.57 & & 13.3 & & 19.4 & & 22.9 & & - & \\
\hline Total octa-furans & 39001-02-0 & $\mathrm{ng} / \mathrm{kg}$ & 13.9 & & 30.5 & & 56.4 & & 62.4 & & - & \\
\hline Total dioxins/furans & na & $\mathrm{ng} / \mathrm{kg}$ & 269 & & 585 & & 667 & & 801 & & - & \\
\hline Total dioxins/furans & na & ng TEQ/kg & 1.27 & $\mathrm{~J}$ & 2.73 & $\mathrm{~J}$ & 3.12 & $\mathrm{~J}$ & 4.20 & $\mathrm{~J}$ & - & \\
\hline \multicolumn{13}{|c|}{ Polychlorinated biphenyl homologues (by high-resolution mass spectrometry [HRMS]) } \\
\hline Total monochloro biphenyls & 27323-18-8 & $\mathrm{ng} / \mathrm{kg}$ & 6.21 & & 13.4 & & 8.07 & & 12.4 & & - & \\
\hline Total dichloro biphenyls & $25512-42-9$ & $\mathrm{ng} / \mathrm{kg}$ & 107 & & 154 & & 191 & & 173 & & - & \\
\hline Total trichloro biphenyls & 25323-68-6 & $\mathrm{ng} / \mathrm{kg}$ & 233 & & 322 & & 294 & & 326 & & - & \\
\hline Total tetrachloro biphenyls & 26914-33-0 & $\mathrm{ng} / \mathrm{kg}$ & 397 & & 601 & & 533 & & 672 & & - & \\
\hline Total pentachloro biphenyls & 25429-29-2 & $\mathrm{ng} / \mathrm{kg}$ & 639 & & 1,160 & & 1,110 & & 1,540 & & - & \\
\hline Total hexachloro biphenyls & 26601-64-9 & $\mathrm{ng} / \mathrm{kg}$ & 582 & & 1,030 & & 1,130 & & 1,520 & & - & \\
\hline Total heptachloro biphenyls & 28655-71-2 & $\mathrm{ng} / \mathrm{kg}$ & 308 & & 408 & & 594 & & 744 & & - & \\
\hline Total octachloro biphenyls & $55722-26-4$ & $\mathrm{ng} / \mathrm{kg}$ & 101 & & 168 & & 258 & & 268 & & - & \\
\hline Total nonachloro biphenyls & $53742-07-7$ & $\mathrm{ng} / \mathrm{kg}$ & 35.6 & & 49.9 & & 82.2 & & 72.9 & & - & \\
\hline Total decachloro biphenyls & $2051-24-3$ & $\mathrm{ng} / \mathrm{kg}$ & 16.3 & & 22.7 & & 15.9 & & 30.5 & & - & \\
\hline Total PCBs (by HRMS) & $1336-36-3$ & $\mathrm{ng} / \mathrm{kg}$ & 2,430 & & 3,930 & & 4,210 & & 5,360 & & - & \\
\hline \multicolumn{13}{|c|}{ Polychlorinated biphenyl Aroclors (by high-resolution mass spectrometry [HRMS]) } \\
\hline Aroclor 1242 & $53469-21-9$ & $\mathrm{ng} / \mathrm{kg}$ & 397 & & 553 & & 505 & & 571 & & - & \\
\hline Aroclor 1254 & 11097-69-1 & $\mathrm{ng} / \mathrm{kg}$ & 991 & & 1,740 & & 1,670 & & 2,320 & & - & \\
\hline Aroclor 1260 & 11096-82-5 & $\mathrm{ng} / \mathrm{kg}$ & 676 & & 796 & & 1,370 & & 1,710 & & - & \\
\hline \multicolumn{13}{|c|}{ Polychlorinated biphenyl Aroclors (by low-resolution mass spectrometry [LRMS]) } \\
\hline Aroclor 1242 & 53469-21-9 & $\mu \mathrm{g} / \mathrm{kg}$ & - & & - & & - & & - & & - & \\
\hline Aroclor 1254 & 11097-69-1 & $\mu \mathrm{g} / \mathrm{kg}$ & - & & - & & - & & - & & - & \\
\hline Aroclor 1260 & $11096-82-5$ & $\mu \mathrm{g} / \mathrm{kg}$ & - & & - & & - & & - & & - & \\
\hline
\end{tabular}




\section{Bed-Sediment Chemistry Data}

Results from the bed-sediment samples are presented by date, but were not storm driven. Rather, all samples were collected during low-flow, low-precipitation conditions when the 72-hour antecedent rainfall was less than $0.2 \mathrm{in.} \mathrm{In}$ the six bulk bed-sediment samples $(<2 \mathrm{~mm})$, TOC, metals, VOCs and other semivolatile compounds, PAHs, dioxins/ furans, and PCBs were detected (table 11). TOC ranged from 1.28 to 2.27 percent. Total cPAHs ranged from 5.91 to $17.6 \mu \mathrm{TEQ} / \mathrm{kg}$. Total dioxins/furans ranged from 0.620 ng TEQ/kg (J-qualified) to $0.944 \mathrm{ng} \mathrm{TEQ} / \mathrm{kg}$ (J-qualified). Total PCBs ranged from 1,390 to 3,710 ng/kg. Eleven metals were detected-the same nine detected in suspended-sediment samples, plus beryllium and cadmium. Numerous VOCs and other semivolatile compounds were detected, including benzyl alcohol, benzoic acid, and bis(2-ethylhexyl)phthalate.

During each of the last three bed-sediment sampling periods, a fine bed-sediment sample $(<62.5 \mu \mathrm{m})$ was analyzed in addition to the bulk bed sediment sample. The same groups of compounds that were detected in the bulk bed sediment samples also were detected in the fine bed sediment samples (table 12). TOC ranged from 1.28 to 2.56 percent. Total cPAHs ranged from 14.8 to $22.4 \mu \mathrm{g}$ TEQ $/ \mathrm{kg}$. Total dioxins/furans ranged from $1.84 \mathrm{ng} \mathrm{TEQ} / \mathrm{kg}$ (J-qualified) to $4.39 \mathrm{ng} \mathrm{TEQ} / \mathrm{kg}$. Total PCBs ranged from 3,280 ng $/ \mathrm{kg}$ to $8,680 \mathrm{ng} / \mathrm{kg}$. The same metals that were detected in bulk bed sediment samples were detected in fine bed sediment samples, except for beryllium. Diethylphthalate and butyl tin were detected in fine bed material, but not bulk bed material.

In 78 percent of cases where analyte concentrations were compared between paired bulk and fine bed sediment samples, the concentration in the fine bed sediment sample $(<62.5 \mu \mathrm{m})$ was greater than the concentration in the bulk bed sediment sample $(<2 \mathrm{~mm})$. Total organic carbon increased by an average of 16 percent in the fine sediment as compared to the bulk sediment. Concentrations of individual metals increased between 21 percent (barium) and 400 percent (mercury). Total dioxins/furans (as ng TEQ/kg) increased to between 150 and 370 percent. Total PCBs (as ng/kg) ranged from less than 5 percent difference to 325 percent. Numerous PAHs had lower concentrations in the fine sediment than in the bulk sediment, particularly the LPAH compounds (average LPAH percent difference $=-23$ percent). The HPAH compounds and the total cPAHs (as $\mu \mathrm{g} \mathrm{TEQ} / \mathrm{kg}$ ) increased in fine sediment as compared to bulk sediment (46 and 47 percent, respectively). 


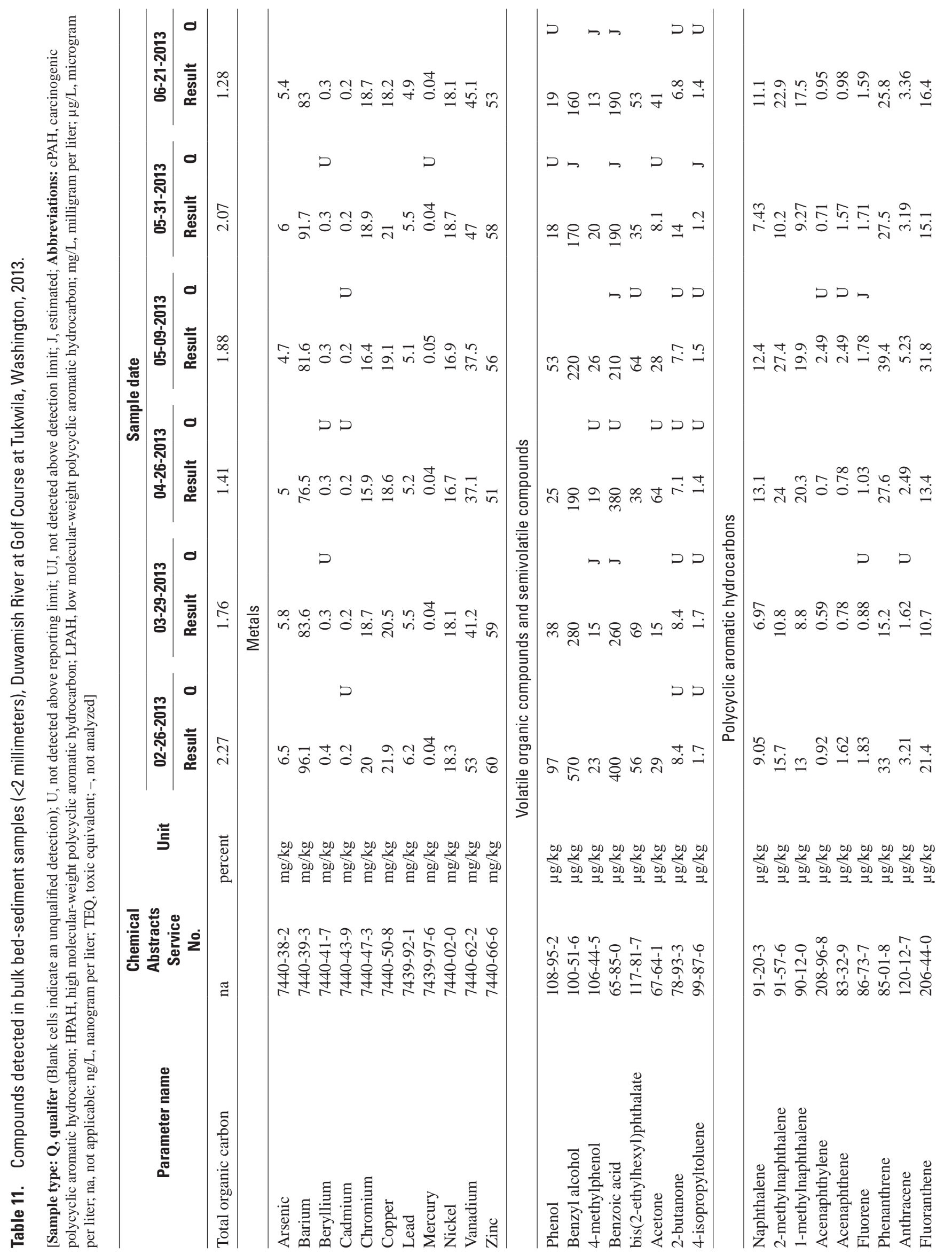




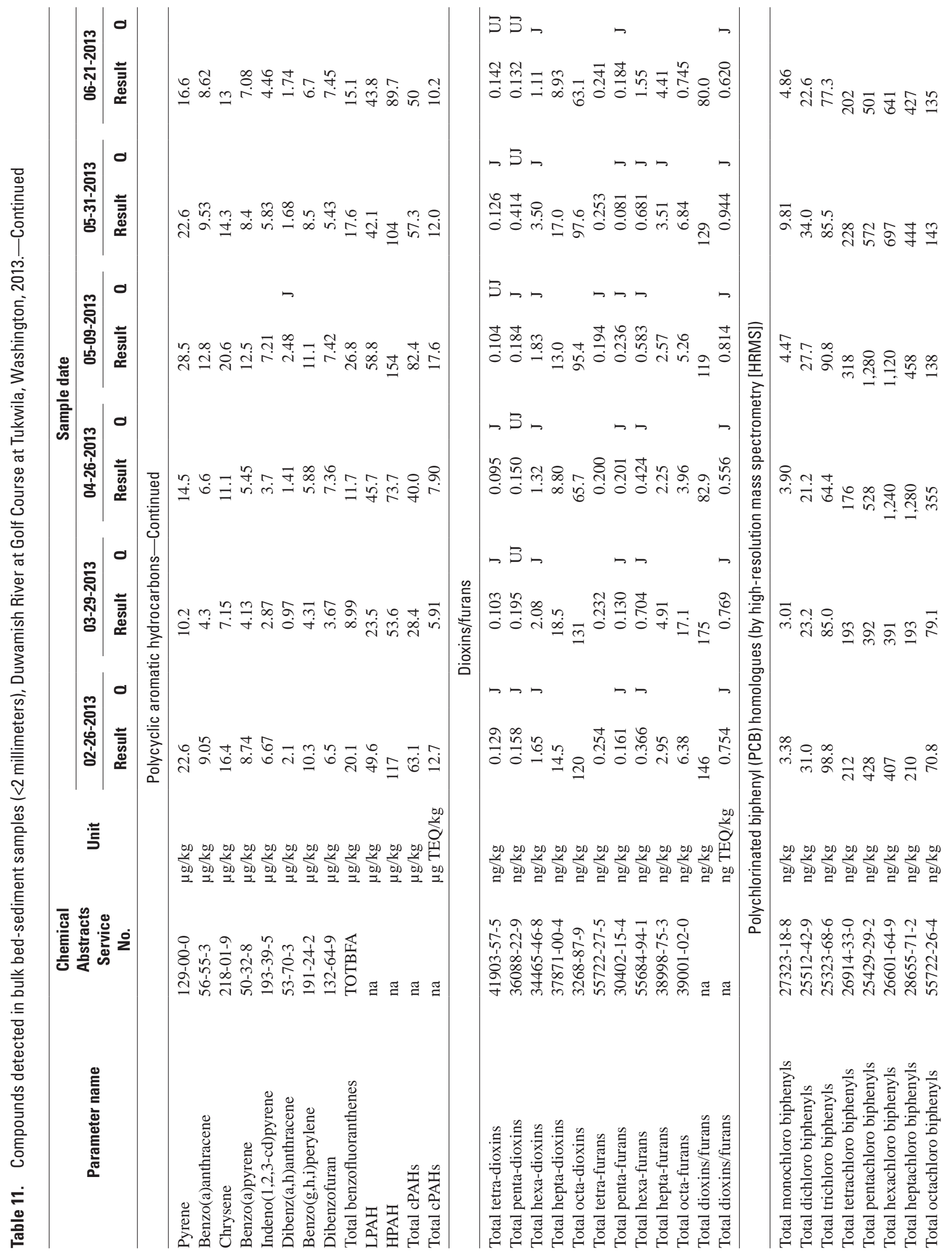




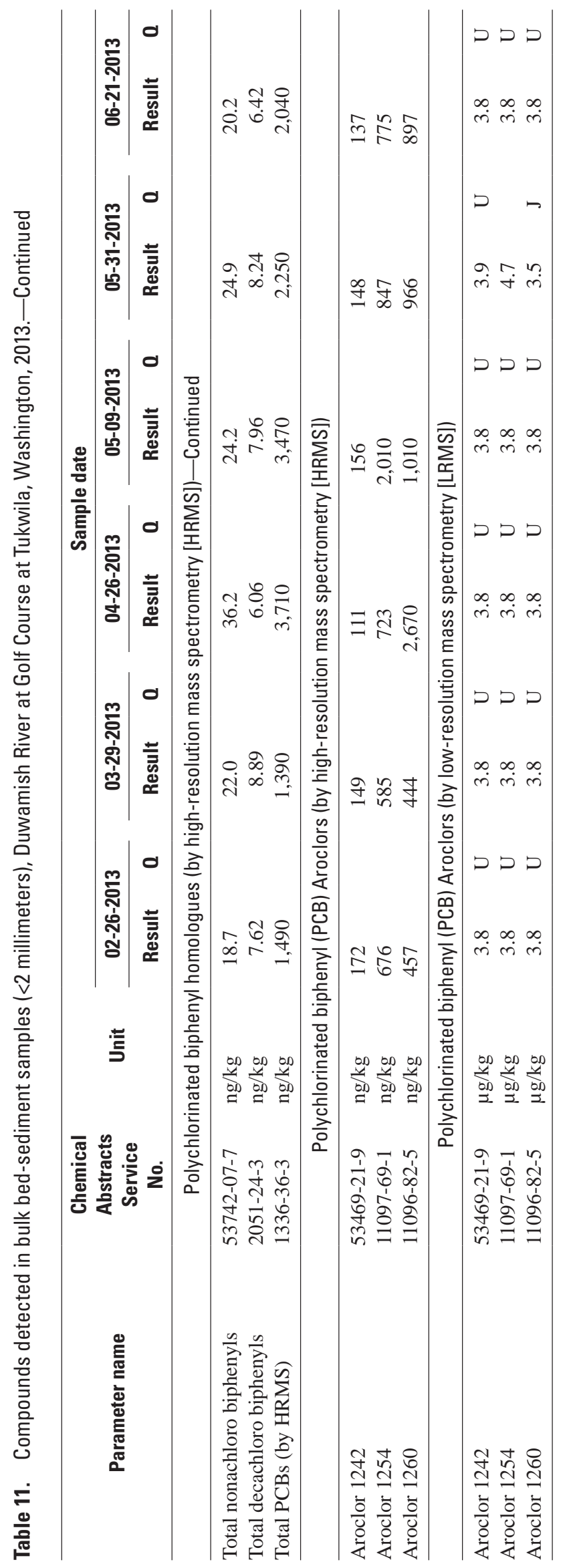


Table 12. Compounds detected in fine bed sediment samples (<62.5 micrometers), Duwamish River at Golf Course at Tukwila, Washington, 2013.

[Sample type: Q, qualifer (Blank cells indicate an unqualified detection); U, not detected above reporting limit; UJ, not detected above detection limit; J, estimated; Abbreviations: cPAH, carcinogenic polycyclic aromatic hydrocarbon; HPAH, high molecular-weight polycyclic aromatic hydrocarbon; LPAH, low molecular-weight polycyclic aromatic hydrocarbon; mg/kg, milligram per kilogram; mg/L; na, not applicable; ng/L, nanogram per liter; TEQ, toxic equivalent; VOCs, volatile organic compounds; $\mu \mathrm{g} / \mathrm{L}$, microgram per liter; $\mu \mathrm{g} / \mathrm{kg}$, microgram per kilogram; -, not analyzed]

\begin{tabular}{|c|c|c|c|c|c|c|c|c|}
\hline \multirow{3}{*}{ Parameter name } & \multirow{3}{*}{$\begin{array}{c}\text { Chemical } \\
\text { Abstracts } \\
\text { Service } \\
\text { No. }\end{array}$} & \multirow{3}{*}{ Unit } & \multicolumn{6}{|c|}{ Sample date } \\
\hline & & & \multicolumn{2}{|c|}{$05-09-2013$} & \multicolumn{2}{|c|}{ 05-31-2013 } & \multicolumn{2}{|c|}{ 06-21-2013 } \\
\hline & & & Result & $\mathbf{0}$ & Result & $\mathbf{0}$ & Result & $\mathbf{0}$ \\
\hline Total organic carbon & na & percent & 2.56 & & 2.34 & & 1.28 & \\
\hline \multicolumn{9}{|c|}{ Metals } \\
\hline Arsenic & $7440-38-2$ & $\mathrm{mg} / \mathrm{kg}$ & 7.4 & & 10.2 & & 10.6 & \\
\hline Barium & 7440-39-3 & $\mathrm{mg} / \mathrm{kg}$ & 99 & & 134 & & 114 & \\
\hline Cadmium & $7440-43-9$ & $\mathrm{mg} / \mathrm{kg}$ & 0.3 & $\mathrm{U}$ & 0.4 & & 0.4 & \\
\hline Chromium & $7440-47-3$ & $\mathrm{mg} / \mathrm{kg}$ & 24 & & 31 & & 27 & \\
\hline Copper & $7440-50-8$ & $\mathrm{mg} / \mathrm{kg}$ & 32 & & 39 & & 33 & \\
\hline Lead & 7439-92-1 & $\mathrm{mg} / \mathrm{kg}$ & 9.9 & & 11.7 & & 10.8 & \\
\hline Mercury & 7439-97-6 & $\mathrm{mg} / \mathrm{kg}$ & 0.1 & & 0.09 & & 0.2 & \\
\hline Nickel & $7440-02-0$ & $\mathrm{mg} / \mathrm{kg}$ & 25 & & 28 & & 24 & \\
\hline Vanadium & $7440-62-2$ & $\mathrm{mg} / \mathrm{kg}$ & 54.6 & & 73.5 & & 63 & \\
\hline Zinc & $7440-66-6$ & $\mathrm{mg} / \mathrm{kg}$ & 80 & & 90 & & 80 & \\
\hline \multicolumn{9}{|c|}{ Volatile organic compounds, semivolatile compounds, others } \\
\hline Phenol & $108-95-2$ & $\mu g / k g$ & - & & 120 & & 20 & $\mathrm{U}$ \\
\hline Benzyl Alcohol & $100-51-6$ & $\mu g / k g$ & - & & 470 & $\mathrm{~J}$ & 560 & \\
\hline 4-Methylphenol & $106-44-5$ & $\mu g / k g$ & - & & 440 & & 20 & $\mathrm{U}$ \\
\hline Benzoic Acid & $65-85-0$ & $\mu g / k g$ & - & & 350 & $\mathrm{~J}$ & 500 & \\
\hline Diethylphthalate & $84-66-2$ & $\mu g / k g$ & - & & 150 & & 53 & $\mathrm{U}$ \\
\hline bis(2-Ethylhexyl)phthalate & $117-81-7$ & $\mu \mathrm{g} / \mathrm{kg}$ & - & & 82 & & 170 & \\
\hline Acetone & 67-64-1 & $\mu \mathrm{g} / \mathrm{kg}$ & - & & - & & 78 & \\
\hline Butyltin & 78763-54-9 & $\mu \mathrm{g} / \mathrm{kg}$ & 2.2 & $\mathrm{~J}$ & 3.5 & $\mathrm{~J}$ & 3.9 & $\mathrm{U}$ \\
\hline \multicolumn{9}{|c|}{ Polycyclic aromatic hydrocarbons } \\
\hline Naphthalene & $91-20-3$ & $\mu \mathrm{g} / \mathrm{kg}$ & 3.97 & & 4.84 & & 7.08 & \\
\hline 2-Methylnaphthalene & $91-57-6$ & $\mu \mathrm{g} / \mathrm{kg}$ & 6.36 & & 4.89 & & 14.7 & \\
\hline 1-Methylnaphthalene & $90-12-0$ & $\mu \mathrm{g} / \mathrm{kg}$ & 3.42 & & 3.08 & & 6.14 & \\
\hline Acenaphthylene & $208-96-8$ & $\mu \mathrm{g} / \mathrm{kg}$ & 0.7 & & 0.59 & & 1.61 & \\
\hline Acenaphthene & $83-32-9$ & $\mu \mathrm{g} / \mathrm{kg}$ & 0.68 & & 0.6 & & 4.38 & \\
\hline Fluorene & $86-73-7$ & $\mu \mathrm{g} / \mathrm{kg}$ & 1.52 & & 1 & & 6.17 & \\
\hline Phenanthrene & $85-01-8$ & $\mu \mathrm{g} / \mathrm{kg}$ & 17.1 & & 13.1 & & 35.8 & \\
\hline Anthracene & $120-12-7$ & $\mu \mathrm{g} / \mathrm{kg}$ & 1.75 & & 1.41 & & 4.51 & \\
\hline Fluoranthene & $206-44-0$ & $\mu \mathrm{g} / \mathrm{kg}$ & 26.3 & & 15.8 & & 37.6 & \\
\hline Pyrene & $129-00-0$ & $\mu \mathrm{g} / \mathrm{kg}$ & 25.6 & & 21.4 & & 36.2 & \\
\hline Benzo(a)anthracene & $56-55-3$ & $\mu \mathrm{g} / \mathrm{kg}$ & 9.25 & & 7.61 & & 15 & \\
\hline Chrysene & 218-01-9 & $\mu \mathrm{g} / \mathrm{kg}$ & 18.2 & & 15 & & 28.7 & \\
\hline Benzo(a)pyrene & $50-32-8$ & $\mu \mathrm{g} / \mathrm{kg}$ & 12.4 & & 10.5 & & 15.2 & \\
\hline Indeno(1,2,3-cd)pyrene & $193-39-5$ & $\mu \mathrm{g} / \mathrm{kg}$ & 9.76 & & 9.01 & & 14 & \\
\hline Dibenz(a,h)anthracene & $53-70-3$ & $\mu \mathrm{g} / \mathrm{kg}$ & 2.6 & & 2.29 & & 3.91 & \\
\hline Benzo(g,h,i)perylene & $191-24-2$ & $\mu \mathrm{g} / \mathrm{kg}$ & 13.9 & & 13.3 & & 19.1 & \\
\hline Dibenzofuran & $132-64-9$ & $\mu \mathrm{g} / \mathrm{kg}$ & 2.33 & & 1.73 & & 7.17 & \\
\hline Total benzofluoranthenes & TOTBFA & $\mu \mathrm{g} / \mathrm{kg}$ & 28.5 & & 22.3 & & 35.8 & \\
\hline LPAH & na & $\mu \mathrm{g} / \mathrm{kg}$ & 25.7 & & 21.5 & & 59.6 & \\
\hline
\end{tabular}


Table 12. Compounds detected in fine bed sediment samples ( $<62.5$ micrometers), Duwamish River at Golf Course at Tukwila, Washington, 2013.-Continued

\begin{tabular}{|c|c|c|c|c|c|c|c|c|}
\hline \multirow{3}{*}{ Parameter name } & \multirow{3}{*}{$\begin{array}{c}\text { Chemical } \\
\text { Abstracts } \\
\text { Service } \\
\text { No. }\end{array}$} & \multirow{3}{*}{ Unit } & \multicolumn{6}{|c|}{ Sample date } \\
\hline & & & \multicolumn{2}{|c|}{ 05-09-2013 } & \multicolumn{2}{|c|}{ 05-31-2013 } & \multicolumn{2}{|c|}{$06-21-2013$} \\
\hline & & & Result & $\mathbf{0}$ & Result & $\mathbf{0}$ & Result & $\mathbf{0}$ \\
\hline \multicolumn{9}{|c|}{ Polycyclic aromatic hydrocarbons-Continued } \\
\hline НРAH & na & $\mu \mathrm{g} / \mathrm{kg}$ & 147 & & 117 & & 206 & \\
\hline Total cPAHs & na & $\mu \mathrm{g} / \mathrm{kg}$ & 80.7 & & 66.7 & & 113 & \\
\hline Total cPAHs & na & $\mu g \mathrm{TEQ} / \mathrm{kg}$ & 17.6 & & 14.8 & & 22.4 & \\
\hline \multicolumn{9}{|c|}{ Dioxins/furans } \\
\hline Total tetra-dioxins & 41903-57-5 & $\mathrm{ng} / \mathrm{kg}$ & 0.204 & & 0.345 & UJ & 0.415 & \\
\hline Total penta-dioxins & $36088-22-9$ & $\mathrm{ng} / \mathrm{kg}$ & 0.419 & $\mathrm{~J}$ & 1.17 & & 0.672 & $\mathrm{~J}$ \\
\hline Total hexa-dioxins & $34465-46-8$ & $\mathrm{ng} / \mathrm{kg}$ & 4.36 & $\mathrm{~J}$ & 14.6 & & 6.83 & $\mathrm{~J}$ \\
\hline Total hepta-dioxins & $37871-00-4$ & $\mathrm{ng} / \mathrm{kg}$ & 37.2 & & 73.0 & & 67.2 & \\
\hline Total octa-dioxins & $3268-87-9$ & $\mathrm{ng} / \mathrm{kg}$ & 277 & & 423 & & 489 & \\
\hline Total tetra-furans & $55722-27-5$ & $\mathrm{ng} / \mathrm{kg}$ & 0.468 & & 0.677 & & 0.793 & \\
\hline Total penta-furans & $30402-15-4$ & $\mathrm{ng} / \mathrm{kg}$ & 0.376 & $\mathrm{~J}$ & 0.629 & $\mathrm{~J}$ & 0.275 & $\mathrm{~J}$ \\
\hline Total hexa-furans & 55684-94-1 & $\mathrm{ng} / \mathrm{kg}$ & 1.30 & $\mathrm{~J}$ & 2.84 & $\mathrm{~J}$ & 2.20 & $\mathrm{~J}$ \\
\hline Total hepta-furans & 38998-75-3 & $\mathrm{ng} / \mathrm{kg}$ & 7.39 & & 14.9 & & 13.3 & \\
\hline Total octa-furans & 39001-02-0 & $\mathrm{ng} / \mathrm{kg}$ & 20.6 & & 32.6 & & 34.2 & \\
\hline Total dioxins/furans & na & $\mathrm{ng} / \mathrm{kg}$ & 349 & & 563 & & 614 & \\
\hline Total dioxins/furans & na & ng TEQ/kg & 1.84 & $\mathrm{~J}$ & 4.39 & & 3.03 & $\mathrm{~J}$ \\
\hline \multicolumn{9}{|c|}{ Polychlorinated biphenyl (PCB) homologues (by high-resolution mass spectrometry [HRMS]) } \\
\hline Total monochloro biphenyls & 27323-18-8 & $\mathrm{ng} / \mathrm{kg}$ & 6.06 & & 6.62 & & 10.9 & \\
\hline Total dichloro biphenyls & $25512-42-9$ & $\mathrm{ng} / \mathrm{kg}$ & 44.9 & & 67.4 & & 70.4 & \\
\hline Total trichloro biphenyls & 25323-68-6 & $\mathrm{ng} / \mathrm{kg}$ & 126 & & 183 & & 213 & \\
\hline Total tetrachloro biphenyls & 26914-33-0 & $\mathrm{ng} / \mathrm{kg}$ & 327 & & 513 & & 714 & \\
\hline Total pentachloro biphenyls & 25429-29-2 & $\mathrm{ng} / \mathrm{kg}$ & 847 & & 1,390 & & 2,030 & \\
\hline Total hexachloro biphenyls & 26601-64-9 & $\mathrm{ng} / \mathrm{kg}$ & 1,060 & & 2,000 & & 2,730 & \\
\hline Total heptachloro biphenyls & 28655-71-2 & $\mathrm{ng} / \mathrm{kg}$ & 610 & & 1,420 & & 1,970 & \\
\hline Total octachloro biphenyls & $55722-26-4$ & $\mathrm{ng} / \mathrm{kg}$ & 198 & & 552 & & 758 & \\
\hline Total nonachloro biphenyls & $53742-07-7$ & $\mathrm{ng} / \mathrm{kg}$ & 46.4 & & 103 & & 139 & \\
\hline Total decachloro biphenyls & $2051-24-3$ & $\mathrm{ng} / \mathrm{kg}$ & 17 & & 37.4 & & 41.3 & \\
\hline Total PCBs (by HRMS) & 1336-36-3 & $\mathrm{ng} / \mathrm{kg}$ & 3,280 & & 6,270 & & 8,680 & \\
\hline \multicolumn{9}{|c|}{ Polychlorinated biphenyl (PCB) Aroclors (by high-resolution mass spectrometry [HRMS]) } \\
\hline Aroclor 1242 & 53469-21-9 & $\mathrm{ng} / \mathrm{kg}$ & 217 & & 324 & & 375 & \\
\hline Aroclor 1254 & 11097-69-1 & $\mathrm{ng} / \mathrm{kg}$ & 1,240 & & 2,020 & & 2,980 & \\
\hline Aroclor 1260 & 11096-82-5 & $\mathrm{ng} / \mathrm{kg}$ & 1,350 & & 3,070 & & 4,220 & \\
\hline \multicolumn{9}{|c|}{ Polychlorinated biphenyl (PCB) Aroclors (by low-resolution mass spectrometry [LRMS]) } \\
\hline Aroclor 1242 & 53469-21-9 & $\mu \mathrm{g} / \mathrm{kg}$ & 15 & $\mathrm{U}$ & 3.9 & $\mathrm{U}$ & 4 & $\mathrm{U}$ \\
\hline Aroclor 1254 & 11097-69-1 & $\mu \mathrm{g} / \mathrm{kg}$ & 15 & $\mathrm{U}$ & 4.6 & & 12 & \\
\hline Aroclor 1260 & 11096-82-5 & $\mu \mathrm{g} / \mathrm{kg}$ & 15 & $\mathrm{U}$ & 3.2 & $\mathrm{~J}$ & 12 & \\
\hline
\end{tabular}




\section{Comparison of Suspended-Sediment and Bed-Sediment Data}

Average concentrations of individual compounds (table 13) in suspended sediment $(\mathrm{n}=2-4)$ were greater than average concentrations in fine bed sediment $(n=3)$, which were greater than average concentrations in bulk bed-sediment samples $(n=6)$. Average concentrations of LPAH in bed sediment, however, were greater than in fine bed sediment. Additionally, average total dioxin/furan TEQ concentrations, total PCBs, Aroclor 1254, and Aroclor 1260 were greater in fine bed sediment than in suspended sediment. Suspendedsediment samples were collected on days targeting high flow and (or) high suspended sediment, whereas the bed-sediment samples were collected on different days targeting lowflow conditions ( 72 -hour antecedent rainfall $<0.2$ in). When the dry weight concentrations were normalized for organic carbon content (table 13), the average concentrations of dioxins/furans and PCBs in fine bed sediment were greater than average concentrations in suspended sediment and bulk bed sediment. In contrast, LPAHs were highest in bulk bed sediment, and HPAHs and total cPAHs were highest in suspended sediment.

The bed-sediment grain-size distribution was similar across the six sampling periods (fig. 5). Between 89.3 and 93.2 percent of the weight was comprised of particles less than or equal to $250 \mu \mathrm{m}$, with most of the total weight (64.4-78.0 percent) comprised of particles between 62.5 and $250 \mu \mathrm{m}$, whereas 15.1-24.9 percent was fine material less than 62.5 $\mu \mathrm{m}$. In contrast, the percentage of fine material less than 62.5 $\mu \mathrm{m}$ for the suspended-sediment samples was higher, ranging from 44 percent during the storm peak to 80 percent during a low-precipitation period. A full particle-size analysis of the storm-peak suspended-sediment sample (fig. 5) indicated that the suspended sediment was comprised of very fine material and large particles. Approximately 25 percent of the stormpeak suspended-sediment weight was comprised of particles smaller than $8 \mu \mathrm{m}$, compared to 4 percent for the bed-sediment samples (fig. 5). Approximately 23 percent of the storm-peak suspended-sediment sample was comprised of particles greater than $250 \mu \mathrm{m}$, compared to 6.8-12.6 percent in bed-sediment samples (fig. 5).

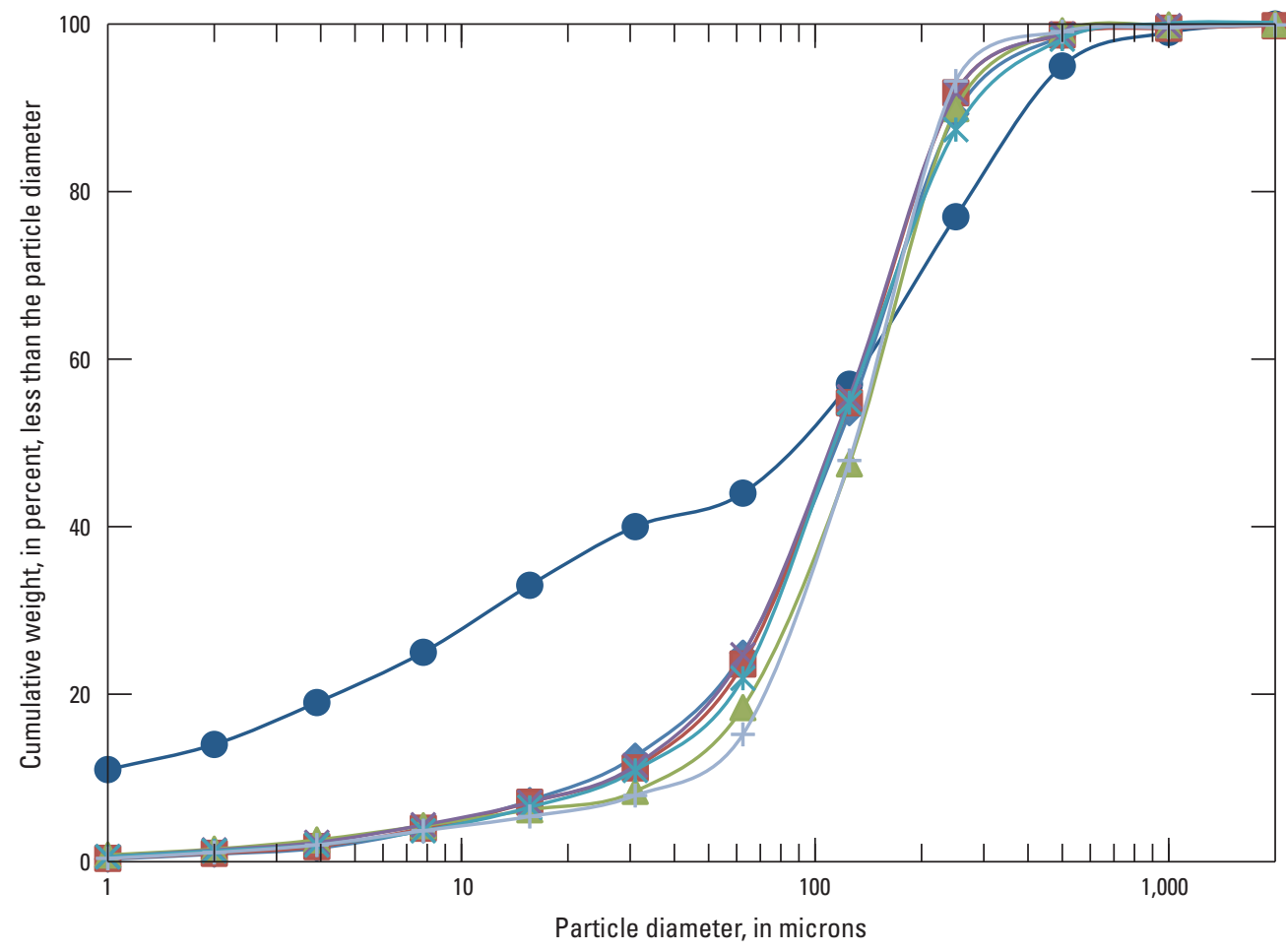

EXPLANATION

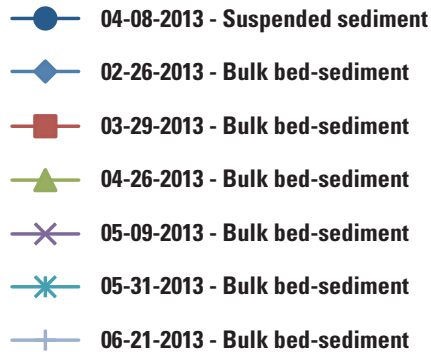

Figure 5. Grain-size distribution of bulk bed-sediment samples ( $<2$ millimeters) and a single storm sample of suspended sediment, Duwamish River at Golf Course at Tukwila, Washington, 2013. 
运害兽 $\mid \begin{aligned} & \text { a } \\ & \mid\end{aligned}$

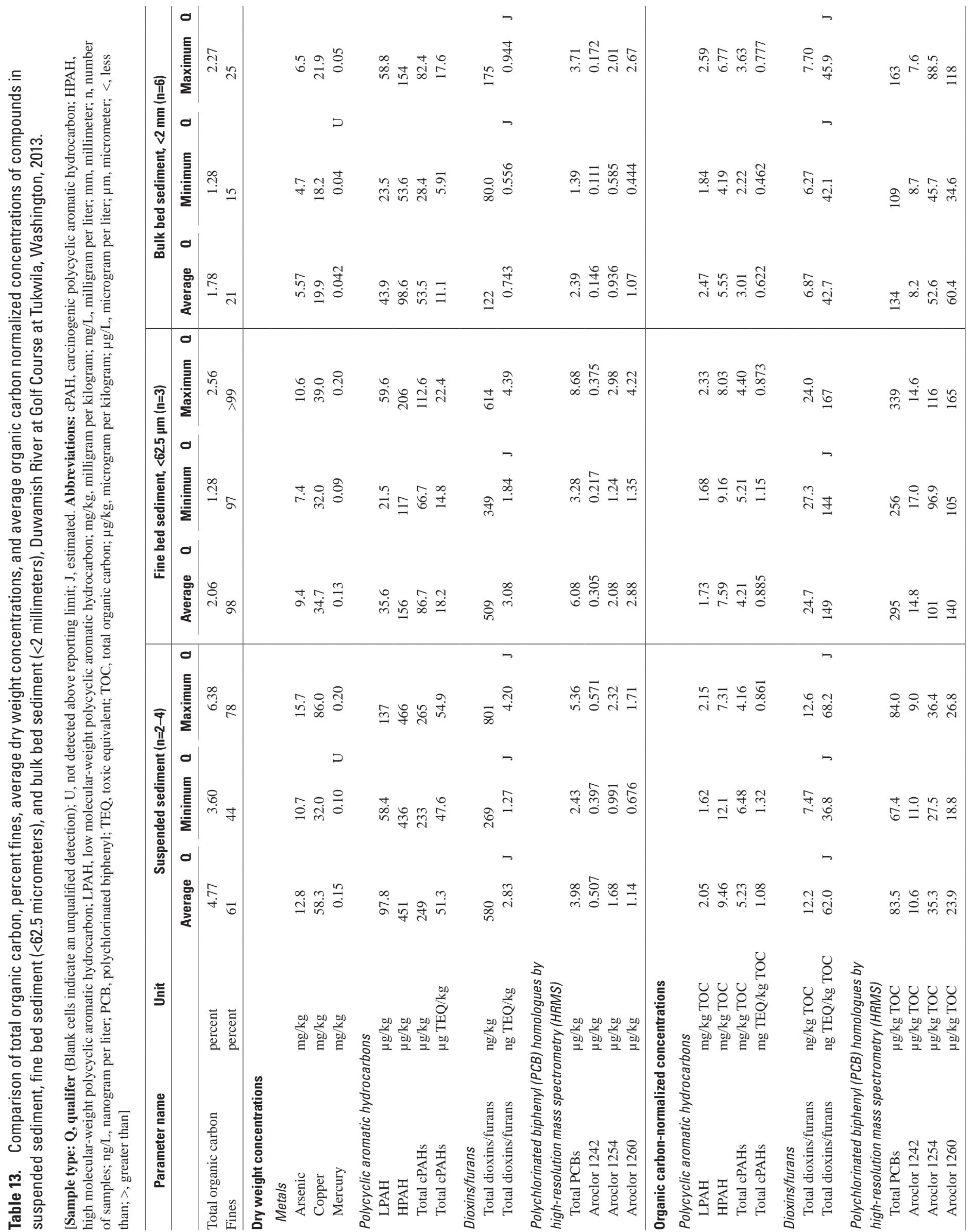




\section{Instantaneous-Load Estimates}

Instantaneous chemical loads based on concentrations in whole water are presented in table 14. The highest loads occurred during the storm-peak sampling because of the high discharge and high whole-water concentrations. For example, TOC loading was $2-5$ times higher, arsenic loading was 3-10 times higher, and total PCBs were $2-8$ times higher during the storm peak than during other sampling periods. Instantaneous suspended-sediment loads (table 15) ranged from approximately $1,000 \mathrm{~kg} / \mathrm{hr}$ during a low-precipitation period to more than $40,000 \mathrm{~kg} / \mathrm{hr}$ during the storm peak. The highest chemical loads based on suspended-sediment chemical concentrations (table 15) occurred during the stormpeak sampling because of the elevated discharge, elevated suspended-sediment concentrations, and elevated chemical concentrations on suspended sediment. For example, TOC loading was 3-11 times higher, arsenic was 6-14 times higher, and total PCBs were more than 50 times higher during the storm peak than during other sampling periods. 


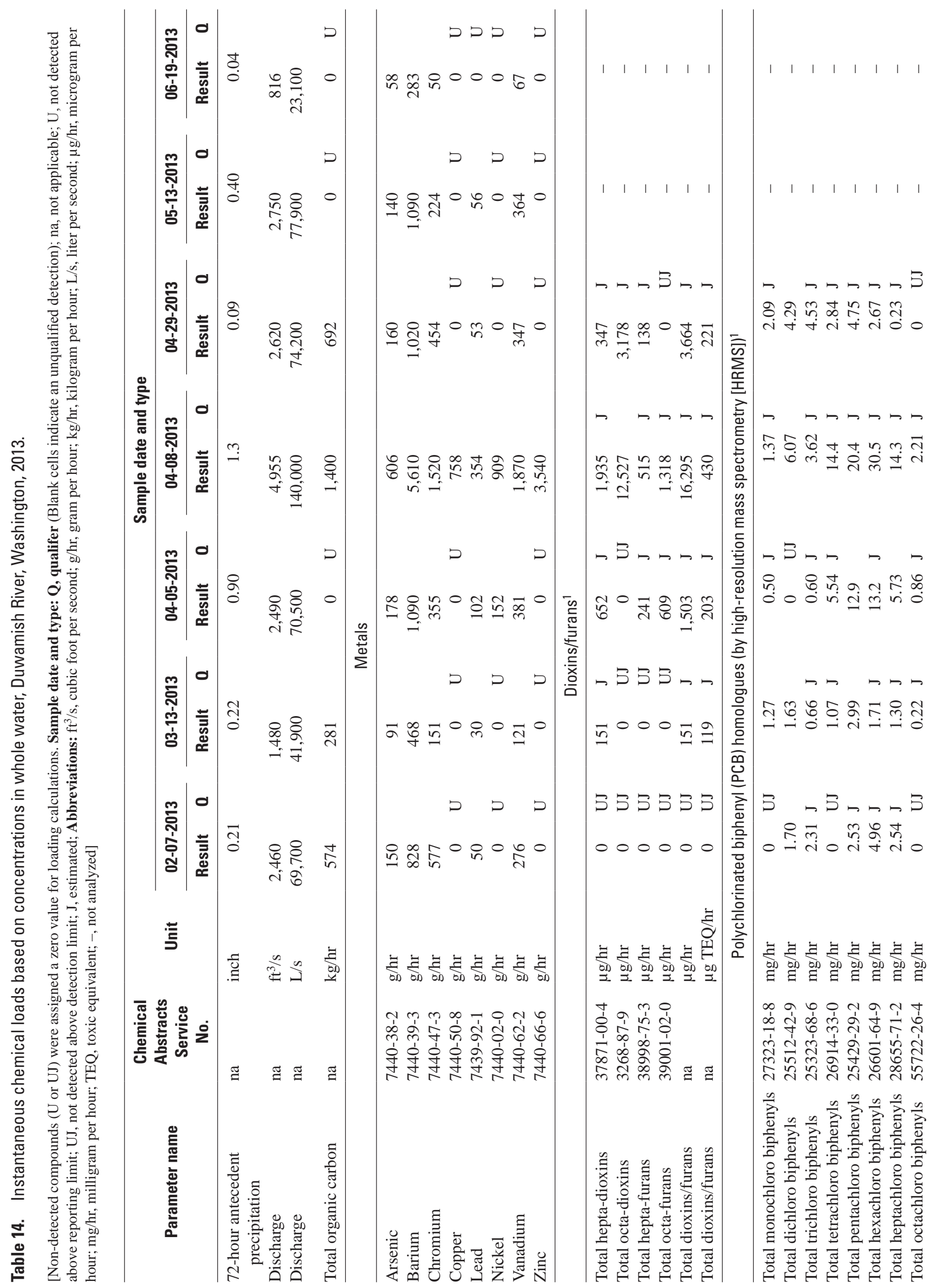




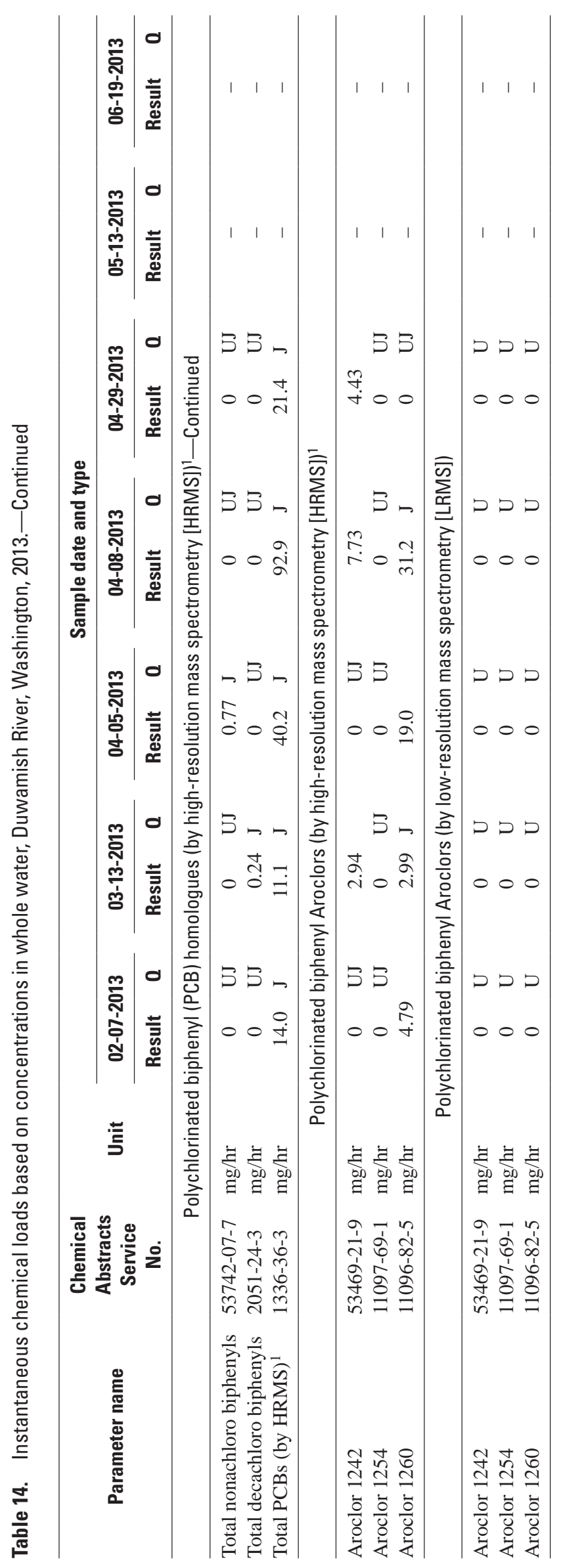




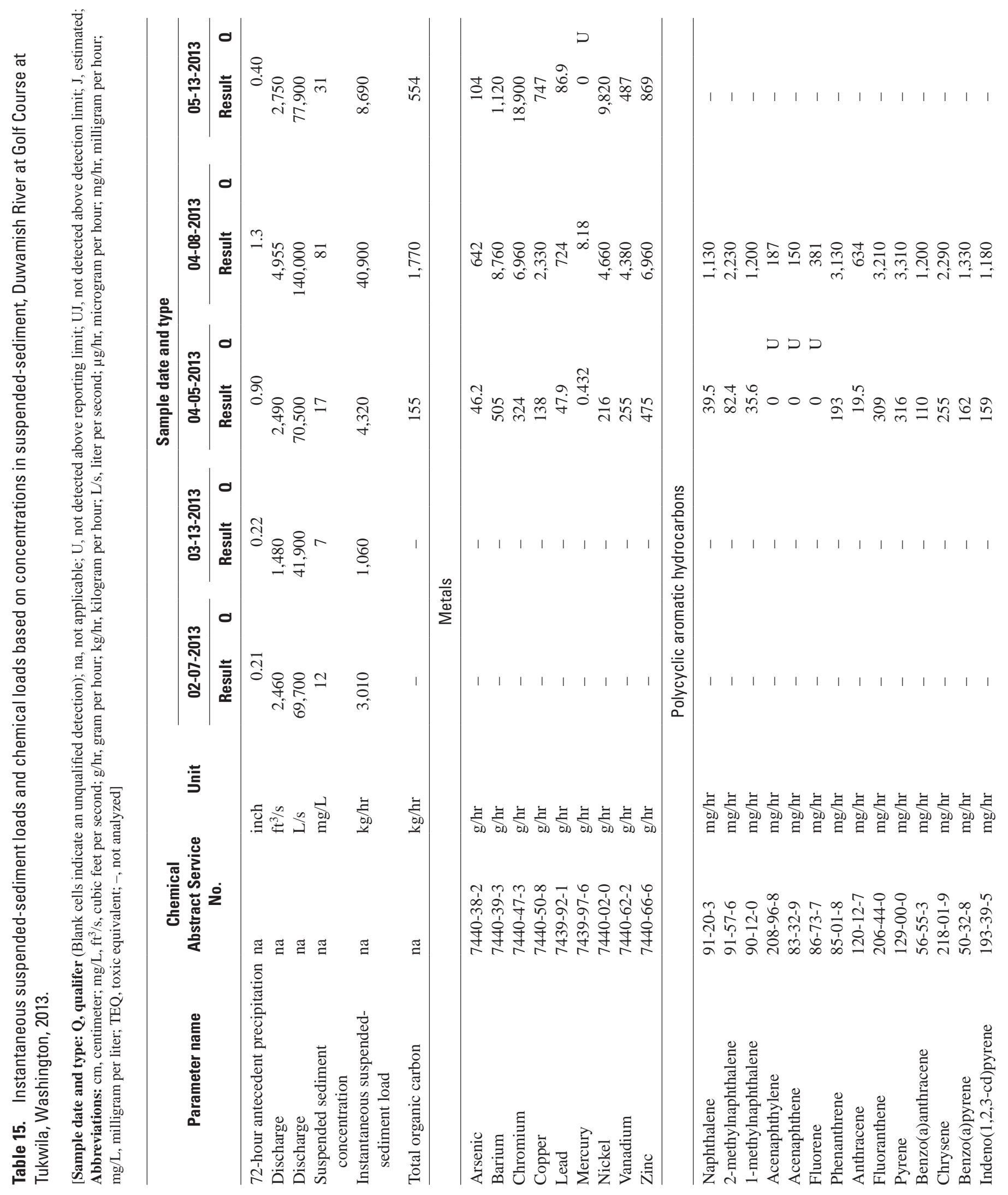



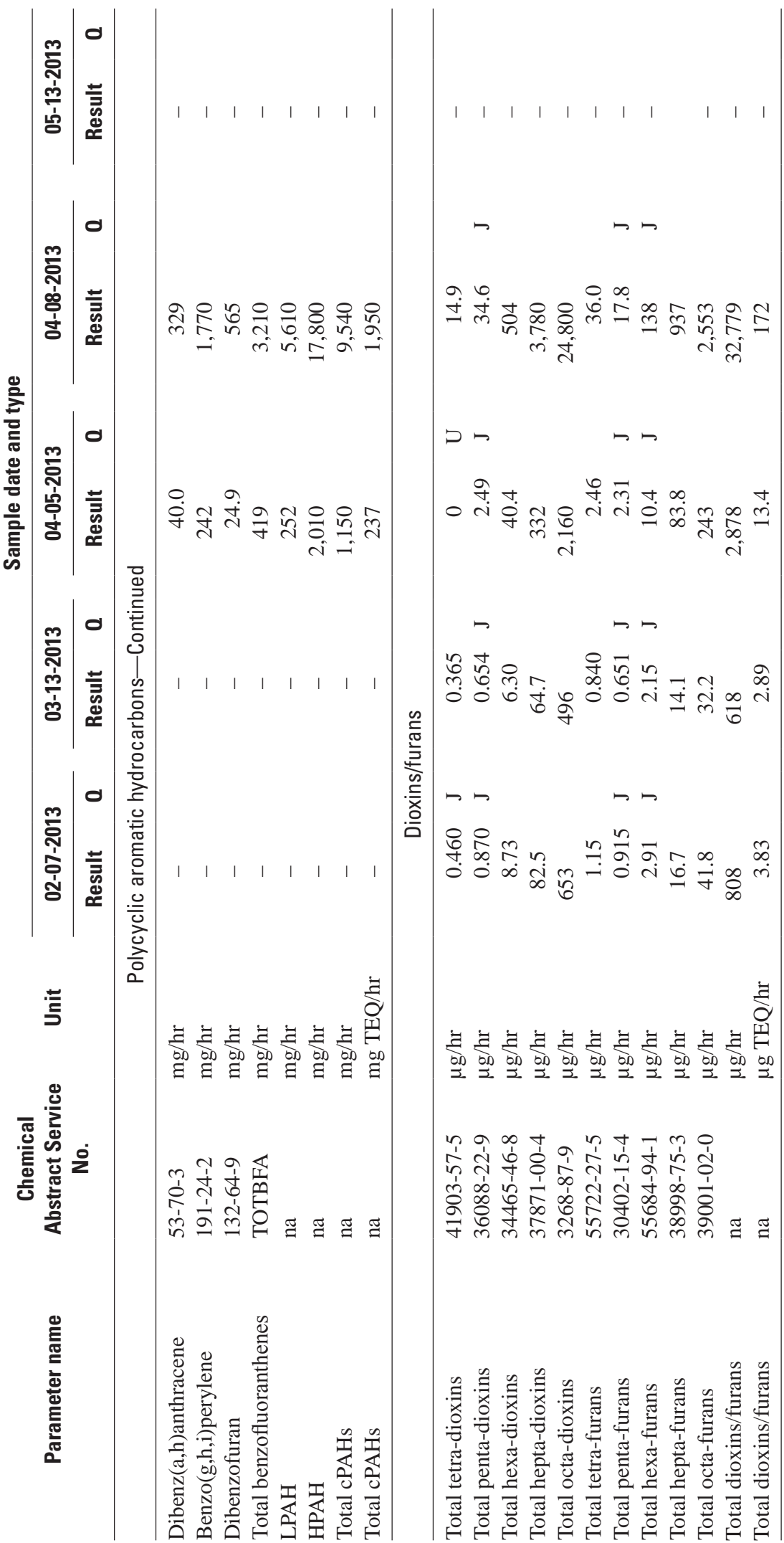

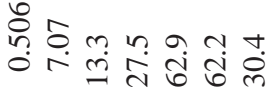

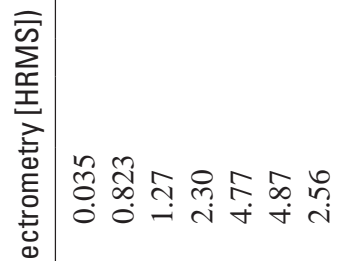

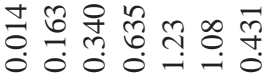

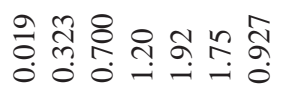

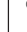

क्र

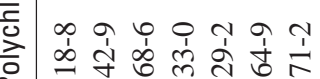

- 7 Ұ

तै

ล

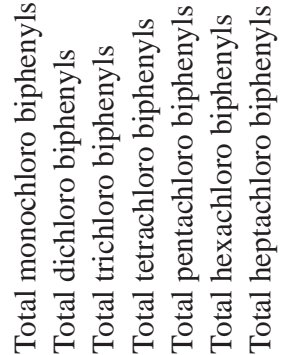




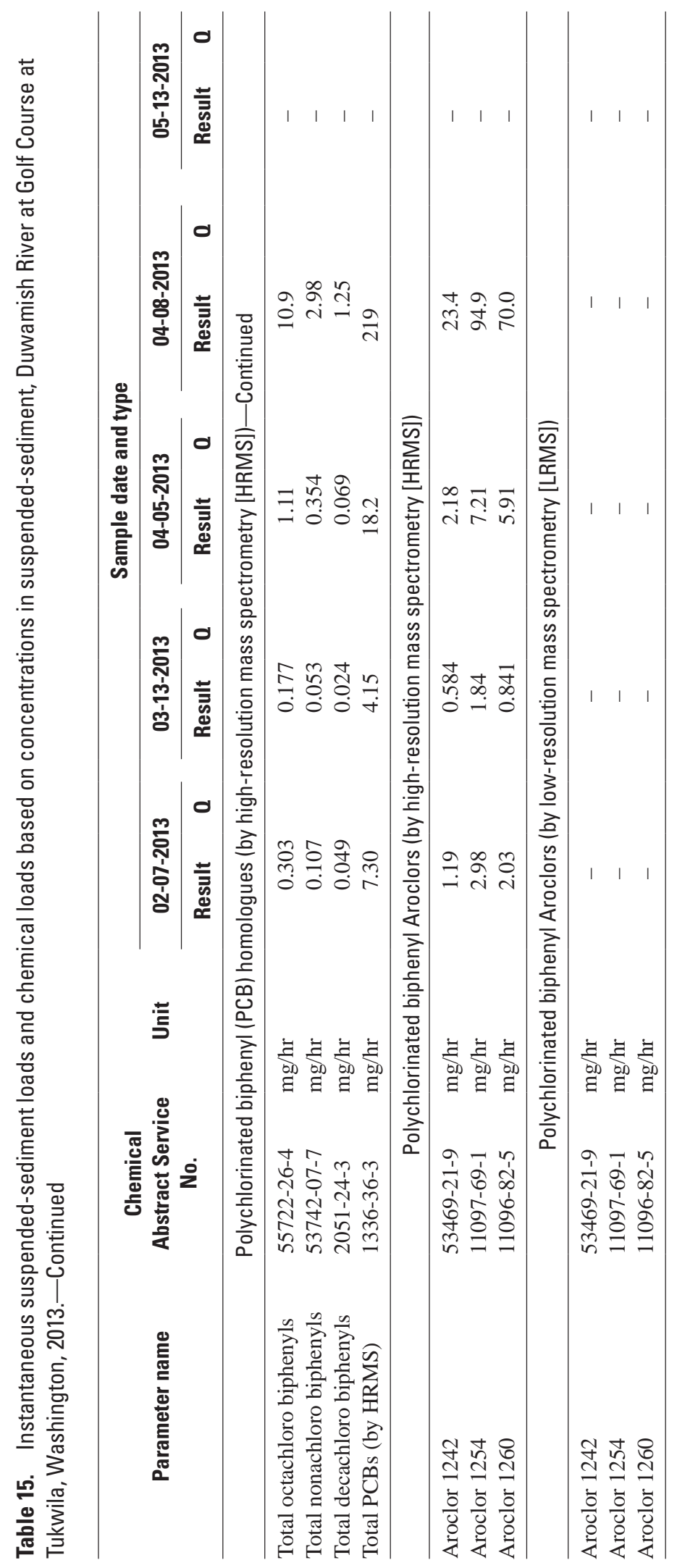




\section{Summary}

Data were collected between February and June 2013 by the U.S. Geological Survey to provide sediment and chemical concentrations and preliminary load estimates to the Lower Duwamish Waterway from upstream sources transported by the Green River, Washington. During five low-precipitation periods, the rising limb of a storm, and the peak of a storm, measurements were collected of instantaneous discharge, field parameters, whole water chemistry, suspended-sediment concentration, and suspended-sediment chemistry. Stream discharge, suspended-sediment concentration, and chemical concentrations in whole water and associated with suspended sediment generally were higher during the storm than during low-precipitation periods. This resulted in higher sediment and chemical-loading estimates during the storm than during lowprecipitation periods.

\section{Acknowledgments}

This work was done under USGS-Ecology Interagency Agreement 13WNWA3005. The following USGS employees and volunteers provided invaluable field and laboratory help: Curtis Chabot, James Foreman, Andrew Gendaszek, Raegan Huffman, Greg Justin, Cameron Marshall, Fred Reed, Rich Sheibley, Stephen Sissel, Andrew Spanjer, and David Steele. We are very grateful to Kelly Smalling and Ronald Baker for conducting the time-intensive Level 4 data validation in a timely manner. We thank Curt Chandler and staff at the Foster Golf Course in Tukwila, Washington for access and use of the bridge and facilities throughout the project.

\section{References Cited}

Black, R.W., and Conn, K.E., 2013, Quality assurance project plan-Assessing sediment and toxic chemical loads from the Green River, WA to the Lower Duwamish Waterway: U.S. Geological Survey, Prepared for Washington State Department of Ecology, 52 p., accessed September 10, 2013, at http://wa.water.usgs.gov/projects/riverloads/ publications.htm.

California Environmental Protection Agency, 2005, Air toxics hot spots program risk assessment guidelines, Part IITechnical support document for describing available cancer potency factors: Office of Environmental Health Hazard Assessment, California Environmental Protection Agency, $587 \mathrm{p}$.
Davis, B.E., and the Federal Interagency Sedimentation Project, 2005, A guide to the proper selection and use of federal approved sediment and water-quality samplers: U.S. Geological Survey Open-File Report 2005-1087, 26 p., accessed February 1, 2013, at http://pubs.usgs.gov/ of/2005/1087/.

Edwards, T.K., and Glysson, G.D., 1999, Field methods for measurement of fluvial sediment: U.S. Geological Survey Techniques of Water-Resources Investigations, book 3, chap. C2, accessed December 4, 2012, at http://pubs.usgs. gov/twri/twri3-c2/html/pdf.html.

Gries, T., and Sloan, J., 2009, Contaminant loading to the lower Duwamish Waterway from suspended sediment in the Green River: Washington State Department of Ecology, Environmental Assessment Program, Report No. 09-03-028, $118 \mathrm{p}$.

Guy, H.P., 1977, Laboratory theory and methods for sediment analysis: U.S. Geological Survey Techniques of WaterResources Investigations, book 5, chap. C1, accessed September 10, 2013, at http://pubs.usgs.gov/twri/twri5c1/ html/pdf.html.

Krone, C.A., Brown, D.W., Burrows, D.G., Chan, S-L, and Varanasi, U.,1989, Butyltins in sediment from marinas and waterways in Puget Sound, Washington State, USA: Marine Pollution Bulletin, v. 20, no. 10, p. 528-31.

Lower Duwamish Waterway Group, 2008, Lower Duwamish Waterway sediment transport modeling report final: Montvale, N.J., Quantitative Environmental Analysis, LLC, Prepared for U.S. Environmental Protection Agency (Region 10 - Seattle, Wash.) and Washington State Department of Ecology (Northwest Regional Office, Bellevue, Wash.), accessed December 4, 2012, at www. ldwg.org/rifs_docs4.htm\#stm.

Lower Duwamish Waterway Group, 2012, Final feasibility study-Lower Duwamish Waterway, Seattle, Washington: Seattle, Wash., AECOM, Prepared for U.S. Environmental Protection Agency (Region 10-Seattle, Wash.) and Washington State Department of Ecology (Northwest Regional Office, Bellevue, Wash.), accessed May 19, 2014, at http://yosemite.epa.gov/R10/CLEANUP.NSF/LDW/Low er+Duwamish+Waterway+Superfund+Site+Technical+Doc uments\#FS.

Mueller, D.S., Wagner, C.R., Rehmel, M.S., Oberg, K.A., and Rainville, Francois, 2009, Measuring discharge with acoustic Doppler current profilers from a moving boat: U.S. Geological Survey Techniques and Methods, book 3, chap. A22, 72 p., accessed February 1, 2013, at http://pubs.water. usgs.gov/tm3a22. 
Plumb, R.H., Jr., 1981, Procedures for handling and chemical analysis of sediment and water samples: Vicksburg, Miss., Environmental Laboratory, U.S. Army Engineer Waterways Experiment Station Technical Committee on Criteria for Dredged and Fill Material, Contract No. EPA-4805572010, 507 p.

Puget Sound Estuary Program, 1986, Recommended protocols for measuring conventional sediment variables in Puget Sound: Bellevue, Wash., Tetra Tech, Inc., Prepared for U.S. Environmental Protection Agency and Puget Sound Water Quality Authority, 44 p.

Radtke, D.B., 2005, Bottom-material samples (ver. 1.1): U.S. Geological Survey Techniques of Water-Resources Investigations, book 9, chap. A8, accessed December 4, 2012, at http://pubs.water.usgs.gov/twri9A8/.

Shelton, L.R., 1997, Field guide for collecting samples for analysis of volatile organic compounds in stream water for the National Water-Quality Assessment Program: U.S. Geological Survey Open-File Report 1997-401, 14 p, accessed February 1, 2013, at http://pubs.er.usgs.gov/ publication/ofr97401.

Shelton, L.R., and Capel, P.D., 1994, Guidelines for collecting and processing samples of stream bed sediment for analysis of trace elements and organic contaminants for the National Water-Quality Assessment Program: U.S. Geological Survey Open-File Report 94-458, accessed December 4, 2012, at http://pubs.er.usgs.gov/publication/ofr94458.

U.S. Environmental Protection Agency, 2008, U.S. Environmental Protection Agency Contract Laboratory Program National functional guidelines for superfund organic methods data review: U.S. Environmental Protection Agency Office of Superfund Remediation and Technology Innovation, Contract No. EPA-540-R-08-01, 225 p., accessed November 25, 2013, at http://www.epa. gov/superfund/programs/clp/guidance.htm.

U.S. Environmental Protection Agency, 2009, Guidance for labeling externally validated laboratory analytical data for superfund use: U.S. Environmental Protection Agency Office of Solid Waste and Emergency Response, Contract No. EPA-540-R-08-005, 29 p., accessed November 25, 2013, at http://www.epa.gov/superfund/programs/clp/ guidance.htm.
U.S. Environmental Protection Agency, 2010, U.S. Environmental Protection Agency Contract Laboratory Program National functional guidelines for inorganic superfund data review: U.S. Environmental Protection Agency Office of Superfund Remediation and Technology Innovation (OSRTI), Contract No. EPA-540-R-10-011, 110 p., accessed November 25, 2013, at http://www.epa.gov/ superfund/programs/clp/guidance.htm.

U.S. Environmental Protection Agency, 2011, U.S. Environmental Protection Agency Contract Laboratory Program National functional guidelines for chlorinated dibenzo-p-dioxins and chlorinated dibenzofurans (CDFs) data review: U.S. Environmental Protection Agency Office of Superfund Remediation and Technology Innovation (OSRTI), Contract No. EPA-540-R-11-016, 62 p., accessed November 25, 2013, at http://www.epa.gov/superfund/ programs/clp/guidance.htm.

U.S. Geological Survey, variously dated, National field manual for the collection of water-quality data: U.S. Geological Survey Techniques of Water-Resources Investigations, book 9, chaps. A1-A9, accessed December 4, 2012, at http:// pubs.water.usgs.gov/twri9A.

Van den Berg and others, 2006, The 2005 World Health Organization re-evaluation of human and mammalian toxic equivalency factors for dioxins and dioxin-like compounds: Toxicological Sciences, v. 93, no. 2, p 223-241.

Wagner, R.J., Kimbrough, R.A., and Turney, G.L., 2007, Quality-assurance plan for water-quality activities in the U.S. Geological Survey Washington Water Science Center: U.S. Geological Survey Open-File Report 2007-1307, 48 p., accessed December 4, 2012, at http://pubs.er.usgs.gov/ publication/ofr20071307.

Washington State Department of Ecology, 2008, Sediment sampling and analysis plan appendix - Guidance on the development of sediment sampling and analysis plans meeting the requirements of the sediment management standards: Toxics Cleanup Program, Washington State Department of Ecology Publication No. 03-09-043, p. E-10-E-11, accessed December 4, 2012, at https://fortress. wa.gov/ecy/publications/summarypages/0309043.html.

Wilde, F.D., Radtke, D.B., Gibs, Jacob, and Iwatsubo, R.T., eds., 2004 with updates through (ver. 2.2): U.S. Geological Survey Techniques of Water-Resources Investigations, book 9, chap. A5, accessed December 4, 2012 at http://pubs. water.usgs.gov/twri9A5/. 


\section{Appendix A. Analytical Laboratory Qualifier Descriptions, Result Amendments, and Complete Analytical Chemistry Results}

Qualifiers were used by each of the two analytical chemistry laboratories and amendments were made to these qualifiers to be consistent with Ecology protocols. Then, the complete analytical results, including non-detected compounds, are reported (with amended qualifiers) in six tables.

The following qualifiers were used by Analytical Resources, Inc. (ARI):

B Analyte detected in an associated method blank at a concentration greater than one-half of ARI's reporting limit (RL), or 5 percent of the regulatory limit, or 5 percent of the analyte concentration in the sample.

$\mathrm{J} \quad$ Estimated concentration when the value is less than ARI's established reporting limits (RL>result>detection limit [DL]).

Q A detected analyte with an initial or continuing calibration that does not meet established acceptance criteria $(<20$ percent Relative Standard Deviation, $<20$ percent drift, or minimum Relative Response Factor).

$\mathrm{U} \quad$ Indicates that the target analyte was not detected at the RL.

Y The analyte was not detected at or above the RL. The RL was raised due to chromatographic interference. The $\mathrm{Y}$ flag is equivalent to the $\mathrm{U}$ flag with a raised reporting limit.
The following qualifiers were used by AXYS Analytical, Ltd.:

B Analyte detected in the sample and the associated blank.

C Congener co-elution.

D Dilution data.

G Disturbance of the mass ion used to monitor instrument performance (lock-mass) present.

$\mathrm{J} \quad$ Indicates an estimated value where the concentration of the analyte is less than the RL, but greater than the detection limit (DL).

K A peak was detected that did not meet all the criteria for identification as the target analyte; the reported value is the estimated maximum possible concentration (EMPC). This is equivalent to the $\mathrm{N}$ qualifier used in Ecology's Environmental Information Management system.

NQ Not quantifiable.

U Not detected at DL.

Differences between various laboratory and agency protocols for coding analytical data to address measurement considerations and (or) abnormalities are common. 
Adjustments to the laboratory-provided qualifiers from laboratories used in this study were made to be consistent with Ecology's Toxics Cleanup Program data reporting protocols (Washington State Department of Ecology, 2008), as outlined in the U.S. Environmental Protection Agency Functional Guidelines (U.S. Environmental Protection Agency, 2008, 2009, 2010, and 2011). Briefly, data that had been flagged or qualified by the laboratory or during the Level 2 or Level 4 review process with qualifiers other than U- and J-containing qualifiers were amended following these protocols:

For non-detect high-resolution mass spectrometery (HRMS) values, the DL was reported with a UJ qualifier.

For all other non-detected analytes, the RL was reported with a $U$ qualifier.

For ease of viewing, informational qualifiers (C and D) were removed.

Y qualifiers were changed to $\mathrm{U}$.

Q-containing qualifiers and G-containing qualifiers were changed to $\mathrm{J}$.

NQ qualifiers were changed to $R$, indicating that the sample was rejected because of the inability to analyze the sample and meet quality control objectives.

$\mathrm{K}$ qualifiers, which can be interpreted as the estimated maximum possible concentration, were changed to UJ.

If the $\mathrm{K}$ was qualifying method blank results, the $\mathrm{B}$ qualifier was removed from associated sample results

B qualifiers were removed or changed according to the following rules:

- If the sample concentration is greater than five times the associated laboratory blank, sample results are considered as positive without qualifiers (action: remove B). For common laboratory contaminants (acetone, 2-butanone, methylene chloride, toluene, phthalate esters), metals, and HRMS compounds, 10 times was used instead of 5 times.
- If the sample concentration was less than 5 times ( $\leq 10$ times was used for common laboratory contaminants, metals, and HRMS compounds), the associated laboratory blank and greater than the RL, it was reported at the detected sample concentration with $\mathrm{U}$ qualifier.

- If the sample concentration was less than or equal to 5 times ( $\leq 10$ times was used for common laboratory contaminants, metals, and HRMS compounds), the associated laboratory blank and less than the RL.

- For non-HRMS compounds, it was reported at the RL with a U qualifier for non-HRMS compounds (there were no cases in this data set).

- For HRMS compounds, it was reported at the detected sample concentration with UJ qualifier.

The data presented in tables A1-A6 are the complete results from Analytical Resources, Inc. and AXYS Analytical, Ltd., with amended qualifiers by the U.S. Geological Survey. The tables can be accessed at http://pubs.usgs.gov/ds/0880.

Table A1. Whole water results, Duwamish River at Golf Course at Tukwila, Washington, 2013.

Table A2. Whole water-quality assurance results, Duwamish River at Golf Course at Tukwila, Washington, 2013.

Table A3. Suspended-sediment results, Duwamish River at Golf Course at Tukwila, Washington, 2013.

Table A4. Suspended-sediment quality assurance results Duwamish River at Golf Course at Tukwila, Washington, 2013.

Table A5. Bed-sediment results, Duwamish River at Golf Course at Tukwila, Washington, 2013.

Table A6. Bed-sediment quality assurance results, Duwamish River at Golf Course at Tukwila, Washington, 2013. 
Publishing support provided by the U.S. Geological Survey

Science Publishing Network, Tacoma Publishing Service Center

For more information concerning the research in this report, contact the Director, Washington Water Science Center

U.S. Geological Survey

934 Broadway, Suite 300

Tacoma, Washington 98402

http://wa.water.usgs.gov 
옺

욜

옹

홍

흠

7

5 